\title{
Soil microbial communities from the alimentary canal of the earthworm Lumbricus terrestris (Oligochaeta: Lumbricidae)
}

Joshua A. Chapman

West Virginia University

Follow this and additional works at: https://researchrepository.wvu.edu/etd

\section{Recommended Citation}

Chapman, Joshua A., "Soil microbial communities from the alimentary canal of the earthworm Lumbricus terrestris (Oligochaeta: Lumbricidae)" (2006). Graduate Theses, Dissertations, and Problem Reports.

2375.

https://researchrepository.wvu.edu/etd/2375

This Thesis is protected by copyright and/or related rights. It has been brought to you by the The Research Repository @ WVU with permission from the rights-holder(s). You are free to use this Thesis in any way that is permitted by the copyright and related rights legislation that applies to your use. For other uses you must obtain permission from the rights-holder(s) directly, unless additional rights are indicated by a Creative Commons license in the record and/ or on the work itself. This Thesis has been accepted for inclusion in WVU Graduate Theses, Dissertations, and Problem Reports collection by an authorized administrator of The Research Repository @ WVU. For more information, please contact researchrepository@mail.wvu.edu. 
Joshua A. Chapman

Thesis submitted to the Davis College of Agriculture, Forestry and Consumer Science at West Virginia University

in partial fulfillment of the requirements

for the degree of

Masters of Science

in

Plant and Soil Science with a concentration in Environmental Microbiology

\author{
Approved by \\ Alan Sexstone Ph.D., Committee Chairperson \\ Gary Bissonnette, Ph.D. \\ William Bryan, Ph.D. \\ James Kotcon, Ph.D.
}

Division of Plant and Soil Sciences

Morgantown, West Virginia

2006

Keywords: Earthworms, Lumbricus terrestris, soil microbial communities, pasture, manure, CLPP, DGGE 


\section{ABSTRACT \\ SOIL MICROBIAL COMMUNITIES FROM THE ALIMENTARY CANAL OF THE EARTHWORM LUMBRICUS TERRESTRIS (OLIGOCHAETA: LUMBRICIDAE)}

by Joshua A. Chapman

The effect of earthworm (Lumbricus terrestris) activity on microbial community composition was investigated in a silt loam soil. Fingerprints were constructed using PCR amplicons of bacterial 16S rDNA separated by denaturing gradient gel electrophoresis.

Analysis of similarity established that significant differences existed between community fingerprints. Differences were explored using non-metric multidimensional scaling (MDS) and unweighted pair-group method with arithmetic mean (UPGMA). Microbial communities of earthworm casts separated from soil treatments for both CD DGGE and CI DGGE profiles. Cast communities were determined by the worm's food source. Soils with earthworms and manure separated from all other soil treatments. Major trends observed above also were evident in separate analyses employing PCR amplification of nirK for DGGE, and BIOLOG ECO MicroPlates ${ }^{\mathrm{TM}}$ for community level physiological profiles (CLPP). Data suggest bacterial communities are modified after ingestion, however resultant changes in the soil bacterial community only occur when earthworms consume a soil manure mixture. 


\section{ACKNOWLEDGEMENTS}

I wish to acknowledge the United States Department of Agriculture (USDA) and the Division of Plant and Soil Sciences, West Virginia University for providing funding for this research. I would like to thank Dr. Alan Sexstone for his assistance and guidance in the direction of my research and preparation of this manuscript. Gratitude also is extended to my committee members: Dr. Gary Bissonnette, Dr. William Bryan, and Dr. James Kotcon for their support. Additionally, I would like to thank my fellow graduate students and my wife Rachel for her patience and understanding. 


\section{TABLE OF CONTENTS}

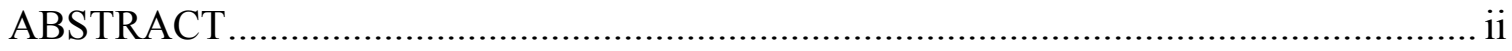

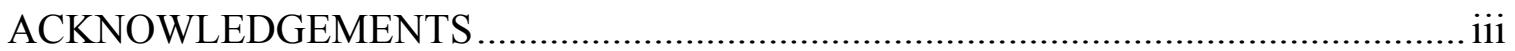

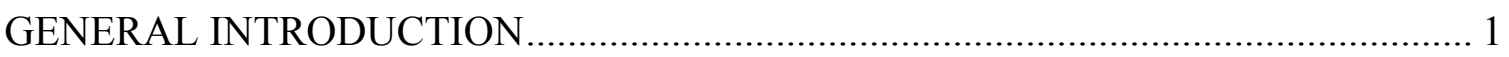

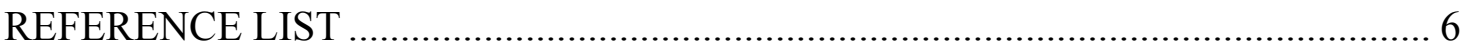

CHAPTER I: MODIFICATION OF BACTERIAL COMMUNITIES IN A PASTURE SOIL BY THE FEEDING ACTIVITY OF EARTHWORMS .......................................... 9

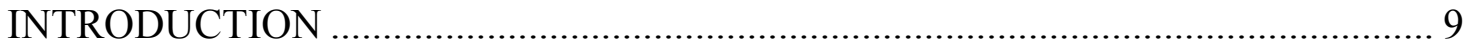

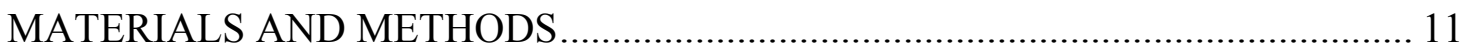

Sample Site and Mesocosoms .......................................................................... 11

Sampling: Soil, Manure and Casts ....................................................................... 13

Heterotrophic Plate Counts ................................................................................... 13

Community Level Physiological Profiles - BIOLOG ${ }^{\circledR}$............................................... 14

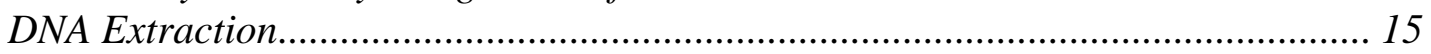

Culture-dependent

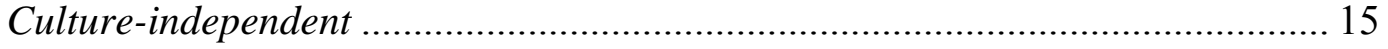

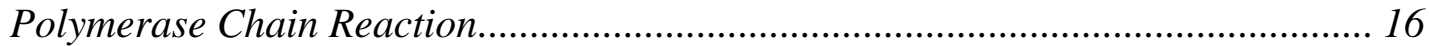

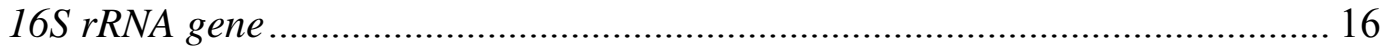

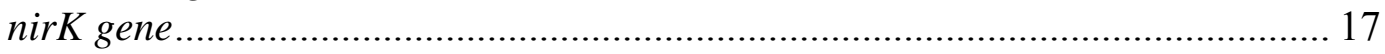

Denaturing Gradient Gel Electrophoresis............................................................ 17

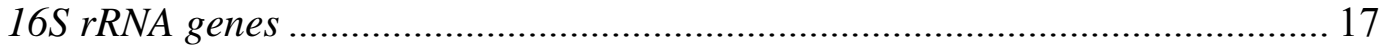

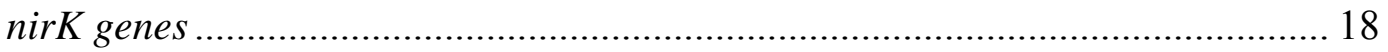

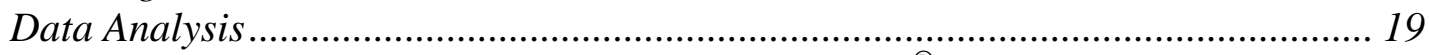

Community Level Physiological Profiles - BIOLOG ${ }^{\circledR}$......................................... 19

Denaturing Gradient Gel Electrophoresis.......................................................... 20

Heterotrophic Plate Counts ............................................................................ 21

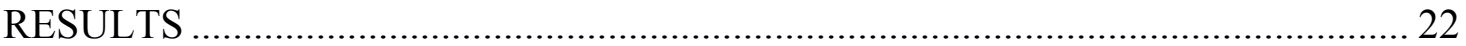

Preliminary Observations and Experimental Design ............................................... 22

Heterotrophic Plate Counts ................................................................................... 22

Community Level Physiological Profiles................................................................ 23

Denaturing Gradient Gel Electrophoresis............................................................ 25 $16 S$ rRNA gene: Comparison of CD DGGE and CI DGGE Bacterial Fingerprints

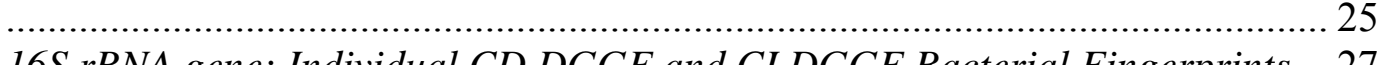

GE Bacterial Fingerprints ... 27

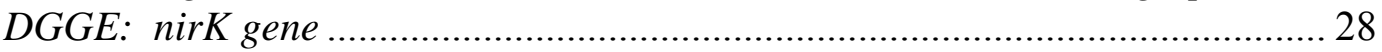

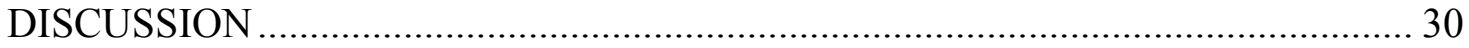

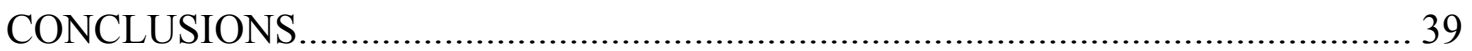

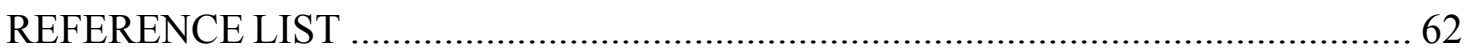

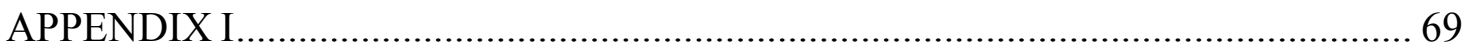

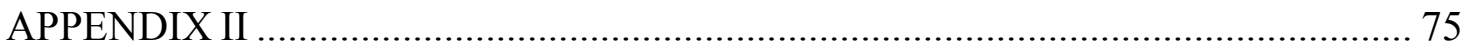




\section{LIST OF TABLES}

Chapter I

Table 1. Description of the experimental treatments............................41

Table 2. Heterotrophic plate counts obtained using R2A medium...................42

Table 3. Bacterial functional diversity indices determined using $\mathrm{BIOLOG}^{\circledR} \ldots \ldots \ldots \ldots . .43$

Table 4. Richness within substrate guilds as determined by utilized substrates..........44

Table 5. Total and unique band counts for combined CD and CI 16S rRNA DGGE.....45

Table 6. Total and unique band counts for combined CD and CI nirK DGGE..........46 


\section{LIST OF FIGURES}

\section{Chapter I}

Figure 1. Depiction of the experimental process..............................47

Figure 2. Experiment 2 flow chart................................................ 48

Figure 3. Principal component analysis based on normalized AWCD from BIOLOG® ECO MicroPlates ${ }^{\mathrm{TM}}$ for pasture soil, L. terrestris casts and manure...........49

Figure 4a. DGGE gel of PCR-amplified 16S rRNA genes amplified from CD and CI bacterial communities of pasture soil and L. terrestris casts................50

Figure 4b. UPGMA dendrogram constructed using the Dice similarity matrix generated from CD and CI DGGE profiles amplified from 16S rRNA genes from pasture soil and casts from $L$. terrestris under different feeding conditions..........50

Figure 5. Multidimensional scaling (MDS) ordination plot based on mean Sorenson similarity values of combined CD and CI 16S rRNA profile of pasture soil and

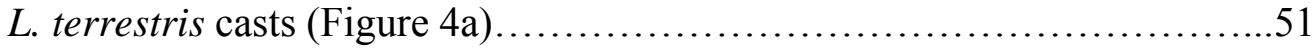

Figure 6a. DGGE gel of PCR-amplified 16S rRNA genes amplified from CD bacterial communities of pasture soil and $L$. terrestris casts.

Figure 6b. UPGMA dendrogram constructed using the Dice similarity matrix generated from CD DGGE profiles amplified from 16S $r R N A$ genes from pasture soil and casts from $L$. terrestris under different feeding conditions.

Figure 7. Multidimensional scaling (MDS) ordination plot based on mean Sorenson similarity values of combined CD 16S rRNA profile of pasture soil and $L$. terrestris casts (Figure 6a)........................................

Figure 8a. DGGE gel of PCR-amplified 16S rRNA genes amplified from CI bacterial communities of pasture soil and $L$. terrestris casts......................54

Figure $8 \mathrm{~b}$. UPGMA dendrogram constructed using the Dice similarity matrix generated from CI DGGE profiles amplified from 16S rRNA genes from pasture soil and casts from $L$. terrestris under different feeding conditions

Figure 9. Multidimensional scaling (MDS) ordination plot based on mean Sorenson similarity values of combined CI $16 \mathrm{~S} r R N A$ profile of pasture soil and $L$. terrestris casts (Figure 8a) ......................................... 55

Figure 10a. DGGE gel of PCR-amplified nirK genes amplified from CD and CI bacterial communities of pasture soil and L. terrestris casts. 
Figure 10b. UPGMA dendrogram constructed using the Dice similarity matrix generated from CD and CI DGGE profiles amplified from nirK genes from pasture soil and casts from $L$. terrestris under different feeding conditions. .56

Figure 11. Multidimensional scaling (MDS) ordination plot based on mean Sorenson similarity values of combined CD and CI nirK profile of pasture soil and $L$. terrestris casts (Figure 10a)..........................................57

Figure 12a. DGGE gel of PCR-amplified nirK genes amplified from CD bacterial communities of pasture soil and $L$. terrestris casts..................... 58

Figure 12b. UPGMA dendrogram constructed using the Dice similarity matrix generated from CD DGGE profiles amplified from nirK genes from pasture soil and casts from $L$. terrestris under different feeding conditions.

Figure 13. Multidimensional scaling (MDS) ordination plot based on mean Sorenson similarity values of CD nirK profile of pasture soil and $L$. terrestris casts

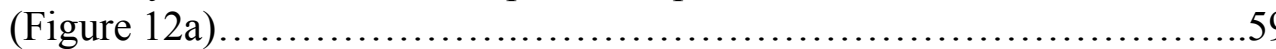

Figure 14a. DGGE gel of PCR-amplified nirK genes amplified from CI bacterial communities of pasture soil and $L$. terrestris casts.

Figure 14b. UPGMA dendrogram constructed using the Dice similarity matrix generated from CI DGGE profiles amplified from nirK genes from pasture soil and casts from $L$. terrestris under different feeding conditions.................60

Figure 15. Multidimensional scaling (MDS) ordination plot based on mean Sorenson similarity values of CI nirK profile of pasture soil and $L$. terrestris casts

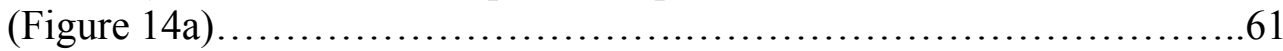




\section{LIST OF APPENDICES}

Chapter I

Appendix IA. Summary flow chart describing a preliminary feasibility study..........69

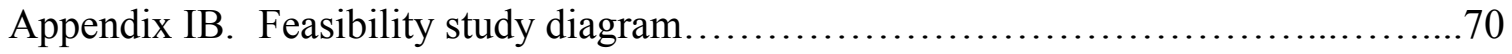

Appendix IC. DGGE gel of PCR amplified 16S rRNA genes amplified from CD bacterial communities of pasture soil and $L$. terrestris casts................71

Appendix ID. UPGMA dendrograms constructed using the Dice similarity matrix generated from CD DGGE profiles of PCR-amplified 16S rRNA genes from pasture soil and casts from $L$. terrestris before and after treatment with cattle manure...........................................71

Appendix IE. DGGE gel of PCR amplified 16S rRNA genes amplified from CI bacterial communities of pasture soil and L. terrestris casts...................72

Appendix IF. UPGMA dendrograms constructed using the Dice similarity matrix generated from CI DGGE profiles of PCR-amplified 16S rRNA genes from pasture soil and casts from $L$. terrestris before and after treatment with cattle manure

Appendix IG. Heterotrophic plate counts enumerations of soil, L. terrestris casts and manure obtained from R2A medium...............................73

Appendix IH. Principal component analysis based on normalized AWCD from

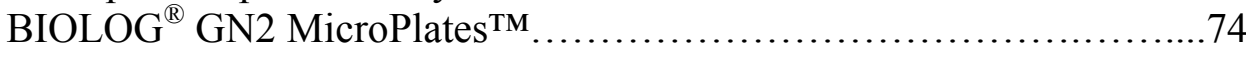

Appendix II. West Virginia University Agricultural Experiment Farm plot map.......75 


\section{GENERAL INTRODUCTION}

Sustainable production of grass-fed pastured beef cattle is dependent on soil fertility and the ability to produce high quality forage. Since 1998, experimental grasslands at the West Virginia University Reedsville Experiment Farm located in

Preston County, WV have been managed to promote sustainable grass-fed beef production. These pastures contain mixtures of orchardgrass (Dactylis glomerata L.), Kentucky bluegrass (Poa pratensis L.), and meadow fescue (Festuca elatior L.) in combination with red clover (Trifolium pretense L.) and white clover (Trifolium repens L.). Periodically, experimental plots are over-seeded with legumes (circa $5 \mathrm{~kg} \mathrm{ha}^{-1}$ ), amended according to two fertility regimes ( $\mathrm{P}, \mathrm{K}$ and lime additions), and the same stocking rate. Nitrogen is supplied by legumes in the pastures and by inputs from animal excreta (urine and manure) deposited by grazing cattle. Distribution of manure in the pasture is uneven resulting in patches where an enhanced microbial activity may lead to changes in soil nutrient cycling and fertility.

Soil quality generally is assessed using a combination of physical, chemical, and microbiological measurements and is operationally defined as the capacity of a soil to function within ecosystem boundaries to sustain biological productivity, maintain environmental quality and promote plant and animal health (Doran and Parkin, 1996). Since microorganisms are responsible for decomposition and recirculation of organic matter in soil, prokaryotic diversity potentially is a useful indicator of soil quality obtained by measuring changes in the composition and function of the soil bacterial community. In a previous study, Sutanto (2005) established experimental subplots at the 
Reedsville farm on high and low fertility pasture sites and amended them with a manure treatment to examine the potential effects on microbial indices of soil quality. She observed shifts in the soil microbial community in these upland pasture soils as a function of the long-term levels of fertilizer input (high vs. low). However, data on the short-term impact of manure pats on soil bacterial communities were more variable, with greater differences generally observed in the upper $5 \mathrm{~cm}$ of soil compared with a $15 \mathrm{~cm}$ profile, suggesting that proximity to the decomposing manure pat was an important determinant. Field observations revealed large numbers of earthworms always were present under decomposing manure pats. The potential impact of earthworms on the redistribution of organic matter and microorganisms present in the manure was not systematically assessed. The working hypothesis of the present thesis was that earthworm feeding behavior affects bacterial community composition in pasture soil.

Earthworms play a major role in the degradation and stabilization of soil organic matter and strongly influence soil quality. Earthworms often are present in higher numbers around organic matter compared with bulk soil (Hendrix et al., 1992). Earthworms consume soil and organic materials which enter the alimentary canal, pass through the digestive tract and are deposited back on the soil as fecal material, commonly referred to as earthworm casts. Earthworms excavate burrows that can extend from surface to subsurface soil horizons. Earthworms affect soil porosity by burrowing and depositing their casts as loosely packed aggregates on the soil surface. The diameter of burrows ranges from 1 to $10 \mathrm{~mm}$ (Lee, 1985). Pore spaces of this size are among the largest found in soil. This increase in soil porosity results in better soil aeration and increased water infiltration rates resulting in reduced erosion from heavy rain events 
(Tomlin et. al., 1995). Earthworms can ingest and turn over large amounts of soil, thus affecting soil structure through the production of high organic matter containing casts that become soil aggregates. In addition, earthworms secrete copious amounts of epidermal mucus that is rich in mucopolysaccharides and proteins which can bind soil particles together (Lee, 1985).

Earthworms have an enormous influence on the dynamics and decomposition of organic matter. Their diet consists mainly of organic detritus in various stages of decay and includes bacteria, fungi, microfauna and mesofauna (Lee, 1985). The distribution of organic residues through the soil is related to the feeding behavior of different species. Anecic species such as Lumbricus terrestris feed mainly on surface organic matter which they incorporate vertically into the soil profile or deposit as residue around the mouth of their burrows (Doube and Brown, 1998). Other earthworm species burrow continuously through the upper soil horizons, mixing organic matter with mineral particles. Earthworms affect nutrient cycling and availability of nutrients in soil. Plant available N, $\mathrm{P}$ and $\mathrm{K}$ often are higher in fresh earthworm casts than in bulk soil (Doube and Brown, 1998).

Interactions between earthworms and soil bacteria still are not well understood. During cast formation in the earthworm gut, bacteria colonize actively decomposing organic residues. Several studies have shown higher microbial numbers in the earthworm gut and in the drilosphere compared to bulk soil (Daniel and Anderson, 1992; Devliegher and Verstraete, 1997; Edwards and Fletcher, 1988; Kristufek et al., 1992; Parle, 1963; Schonholzer et al., 1999; Tomlin et al., 1995; Wolter and Scheu, 1999; Pedersen and Hendriksen, 1993). However, increases in microbial biomass within the earthworm gut 
were not always observed (Daniel and Anderson, 1992; Scheu, 1987, Devliegher and Verstraete, 1995). Recent studies exploring this relationship have found that earthworm gut/cast microbial populations differ from that of soil. Specific phylogenetic groups have been found in higher numbers in earthworm guts/casts such as Proteobacteria (Schonholzer et al., 2002; Devliegher and Verstraete, 1997; Fischer et al., 1995; Furlong et al., 2002) and Actinobacteria (Kristufek et al., 1993). Microbial communities of earthworm guts/casts seem to be mostly derived from their food source but are modified within the earthworm due to different physiological conditions (Furlong et al., 2002; Egert et al., 2004). The microaerophilic intestines of earthworms have been found to activate ingested denitrifiers and other nitrate-dissimilating bacteria, which may impact nitrogen transformations within soils (Ihssen et al., 2003). Earthworms may transport and disseminate specific microbial groups through the soil by their burrowing behavior (Thorpe et al., 1996).

The present study was designed to investigate the influence of earthworms on bacterial populations in pasture soil impacted by cattle manure. Laboratory incubations of pasture soil, manure, and earthworms were performed using replicated soil mesocosms. The objective was to determine if earthworm feeding behavior triggered shifts in soil microbial communities. Molecular approaches (denaturing gradient gel electrophoresis; DGGE), microbial community physiological profiles (CLPP's), and microbial enumerations were employed to address this question. DGGE is a genetic fingerprinting method that allows comparison among samples and detection of shifts in populations over time or under different environmental conditions (McCaig et al., 2001). CLPP's are used to assess the functional diversity of microorganisms based on sole- 
source carbon utilization patterns (Zak et al., 1994). Genetic diversity measured by

DGGE and functional diversity measured by CLPP provide complementary experimental approaches to investigate the potential impact of cattle manure redistribution by

earthworms on bacterial community composition and soil quality in upland pasture soil of northern West Virginia. 


\section{REFERENCE LIST}

Daniel, O., and J. M. Anderson. 1992. Microbial biomass and activity in contrasting soil materials after passage through the gut of the earthworm Lumbricus rubellus Hoffmeister. Soil Biol. Biochem 24:465-470.

Devliegher, W. and W. Verstraete. 1995. Lumbricus terrestris in a soil core experiment: nutrient-enrichment processes (NEP) and gut-associated processes (GAP) and their effect on microbial biomass and microbial activity. Soil Biol. Biochem 27:1573-1580.

Devliegher, W. and W. Verstraete. 1997. Microorganisms and soil physiochemical conditions in the drilosphere of Lumbricus terrestris. Soil Biol. Biochem. 29:1721-1729.

Doran, J. W., and T. B. Parkin. 1996. Quantitative indicators of soil quality: a minimum data set. In: Methods for assessing soil quality. SSSA Spec. Publ. 49 (Doran, J. W. and A. J. Jones, Ed.), pp. 25-38, SSSA, Madison, WI.

Doube, B. M. and G. G. Brown. 1998. Life in a complex community: functional interactions between earthworms, organic matter, microorganisms, and plants. In: Earthworm Ecology (Edwards, C. A., Ed.), pp. 179-211, St. Lucie Press, Boca Raton.

Edwards, C.A. and K. E. Fletcher. 1988. Interactions between earthworms and microorganisms in organic-matter breakdown. Agric. Ecosys. Environ. 24:235247.

Egert, M., S. Marhan, B. Wagner, S. Scheu and M. W. Friedrich. 2004. Molecular profiling of $16 \mathrm{~S}$ rRNA genes reveals diet-related differences of microbial communities in soil, gut and cast of Lumbricus terrestris L. (Oligochaeta: Lumbricidae). FEMS Microbiol. Ecol. 48:187-197.

Fischer, K., D. Hahn, R. I. Amann, O. Daniel and J. Zeyer. 1995. In situ analysis of the bacterial community in the gut of the earthworm Lumbricus terrestris L. by whole-cell hybridization. Can. J. Mircrobiol. 41:666-673.

Furlong, M. A., D. R. Singleton, D. C. Coleman and W. B. Whitman. 2002. Molecular and culture-based analyses of prokaryotic communities from an agricultural soil and the burrows and casts of the earthworm Lumbricus rubellus. Appl. Environ. Microbiol 68:1265-1279.

Hendrix, P. F., B. R. Mueller, R. R. Bruce, G. W. Langdale and R. W. Parmelee. 1992. Abundance and distribution of earthworms in relation to landscape factors on the Georgia Piedmont. Soil Biol. Biochem 24:1357-1361. 
Ihssen, J., M. A. Horn, C. Matthies, A. GoBner, A. Schramm and H. L. Drake. 2003. $\mathrm{N}_{2} \mathrm{O}$-producing microorganisms in the gut of the earthworm Aporrectodea caliginosa are indicative of ingested soil bacteria. Appl. Environ. Microbiol 69:1655-1661.

Kristufek, V., K. Ravasz and V. Pizl. 1992. Changes in densities of bacteria and microfungi during gut transit in Lumbricus rubellus and Aporrectodea caliginosa (Oligochaeta: Lumbricidae). Soil Biol. Biochem. 24:1499-1500.

Kristufek, V., K. Ravasz and V. Pizl. 1993. Actinomycete communities in earthworm guts and surrounding soil. Pedobiologia 37:379-384.

Lee, K. E. 1985. Earthworms: their ecology and relationships with soils and land use. Academic Press, Sydney Australia.

McCaig, A. E., L. A. Glover and J. I. Prosser. 2001. Numerical analysis of grassland bacterial community structure under different land management regimens by using $16 \mathrm{~S}$ ribosomal DNA sequence data and denaturing gradient gel electrophoresis banding patterns. Appl. Environ. Microbiol. 67:4554-4559.

Parle, J. N. 1963. Micro-organisms in the intestines of earthworms. J. Gen. Microbiol. 31:1-11.

Pedersen, J. C. and N. B. Hendriksen. 1993. Effect of passage through the intestinal tract of detritivore earthworms (Lumbricus spp.) on the number of selected Gramnegative and total bacteria. Biol. Fertil. Soils 16:227-232

Scheu, S. 1987. Microbial activity and nutrient dynamics in earthworm casts (Lumbricidae). Biol. Fertil. Soils 5:230-234.

Schonholzer, F., D. Hahn and J. Zeyer. 1999. Origins and fate of fungi and bacteria in the gut of Lumbricus terrestris L. studied by image analysis. FEMS Microbiol. Ecol. 28:235-248.

Schonholzer, F., D. Hahn, B. Zarda and J. Zeyer. 2002. Automated image analysis and in situ hybridization as tools to study bacterial populations in food resources, gut and cast of Lumbricus terrestris L. J. Microbiol. Methods 48:53-68.

Sutanto, Yovita. 2005. Manure from grazing cattle: Effects of soil microbial communities and soil quality in northern West Virginia Pastures. (Masters Thesis, West Virginia University). Retrieved December 10, 2005 from https://eidr.wvu.edu/eidr/documentdata.eIDR?documentid=3933 
Thorpe, I. S., J. I. Prosser, L. A. Glover and K. Killham. 1996. The role of the earthworm Lumbricus terrestris in the transport of bacterial inocula through soil. Biol. Fertil. Soils 23:132-139.

Tomlin, A. D., M. J. Shipitalo, W. M. Edwards and R. Protz. 1995. Earthworms and their influence on soil structure and infiltration. In: Earthworm ecology and biogeography (Hendrix, P. F., Ed.), 159-183. Lewis Publishers, Boca Raton.

Wolter, C., and S. Scheu. 1999. Changes in bacterial numbers and hyphal lengths during the gut passage through Lumbricus terrestris (Lumbricidae, Oligochaeta). Pedobiologia 43:891-900.

Zak, J. C., M. R. Willig, D. L. Moorhead and H. G. Wildman. 1994. Functional diversity of microbial communities: a quantitative approach. Soil Biol. Biochem. 26:1101-1108. 
CHAPTER I: MODIFICATION OF BACTERIAL COMMUNITIES IN A PASTURE SOIL BY THE FEEDING ACTIVITY OF EARTHWORMS

\section{INTRODUCTION}

Agricultural practices affect the diversity of soil microbial populations both temporally and spatially (McCaig et al., 2001). Deposition of cattle manure onto pasture adds nutrients, organic carbon, and large number of microorganisms from the bovine gut microflora (Frostegard et al., 1997). Microbiological hot spots occur in soil as the indigenous soil microbial community responds to the addition of readily decomposable organic matter. Earthworms play a major role in redistribution and recycling of manure through pasture soils and thus may be important determinants of soil microbial community structure (Edwards and Fletcher, 1988). Fertilized temperate pastures are among the most favorable habitats for earthworms, with densities of up to 2000 individuals per $\mathrm{m}^{-2}$ (Edwards and Bohlen, 1996). This translates into a belowground earthworm biomass that can exceed the weight of the surface herbivores supported by pasture grazing (Blakemore, 2002). Earthworms ingest mineral soil and particulate organic matter, mix them with organic secretions in the gut, and then excrete them as fecal pellets called casts. Casts contain microorganisms present in the original food source and also are colonized by gut microorganisms all of which are subsequently deposited into soil. Lumbricus terrestris, the earthworm used in the present study, is an anecic species that forms extensive vertical burrows, pulls organic matter down into them, then excretes casts within the soil matrix or on the soil surface. Deposition onto the soil surface can constitute $90 \%$ of cast production, but casts also persist as stable 
microaggregates in subsurface soils for long periods of time (Whalen et al., 2004; Ge et al., 2001). In temperate grasslands it was estimated that up to $70 \mathrm{tha}^{-1} \mathrm{yr}^{-1}$ of soil was turned over into earthworm casts (Bouche, 1983). The daily rate of earthworm cast production was measured at $60 \mathrm{~g} \mathrm{~m}^{-2} \mathrm{day}^{-1}$ in a grazed New Zealand pasture (Chevallier et al., 2006).

The overall purpose of this study was to explore changes in composition of microbial communities in a silt loam pasture soil as earthworms (Lumbricus terrestris) fed on different food sources. We tested the following hypotheses: i) fingerprints of the microbial community in earthworm casts differ according to food source ii) microbial communities in earthworm casts differ from those in soil iii) deposition of earthworm casts alter the soil microbial community. Fingerprints of bacterial community structure were constructed using PCR amplicons of bacterial 16S rDNA separated by denaturing gradient gel electrophoresis (DGGE). Complementary analyses also were performed employing PCR amplification of nirK for DGGE and BIOLOG ${ }^{\circledR}$ ECO MicroPlates ${ }^{\mathrm{TM}}$ for community level physiological profiles (CLPP). 


\section{MATERIALS AND METHODS}

Sample Site and Mesocosoms

All soils used in this study were collected from pastures on the West Virginia University Research Farm, Reedsville, West Virginia. The pastures are part of a beef cow/calf production system. Soils were a Gilpin silt loam (fine-loamy, mixed, semiactive, mesic Typic Hapludults) and a Wharton silt loam (fine-loamy, mixed, mesic Aquic Hapludults) (Patton, 1959). The predominant grasses in the area were orchard grass (Dactylis glomerata L.), Kentucky bluegrass (Poa pratensis L.), and meadow fescue (Festuca elatior L.) with red clover (Trifolium pretense L.) and white clover (Trifolium repens L.). Since 1998 these experimental pastures have been fertilized with two level of fertilizer inputs; i.e. high fertility (maintain soil available P at $134 \mathrm{~kg} \mathrm{ha}^{-1}$ and available $\mathrm{K}$ at $390 \mathrm{~kg} \mathrm{ha}^{-1}$ ) or low fertility (maintain soil available $\mathrm{P}$ at $67 \mathrm{~kg} \mathrm{ha}^{-1}$ and available $\mathrm{K}$ at $195 \mathrm{~kg} \mathrm{ha}^{-1}$ ). Soil was collected on June 1, 2005 from an area that had not received any experimental treatment, but had been set aside as reserve (area adjacent to plots 35 and 36, Appendices II). Prior to the current experiment the area was a hayfield and received minimum inputs of lime, phosphorus and potassium. The sod layer was removed and soil was collected with a spade at a depth of approximately $15 \mathrm{~cm}$ and put into large plastic bags then transported on ice back to the lab and stored at $4^{\circ} \mathrm{C}$ until the following day. Four mesocosms were constructed from approximately $19 \mathrm{~L}$ (height $=35$ $\mathrm{cm}$, base $=26 \mathrm{~cm})$ cylindrical plastic containers that had ventilation holes $(1 \mathrm{~cm})$ placed in the bottom and side to prevent anaerobic zones. Plastic fine mesh screen $(2 \mathrm{~mm})$ was placed over ventilation holes to prevent earthworms from escaping. Prior to addition of 
soil, mesocosms were surface sterilized with $95 \%$ ethanol and allowed to dry. Soil was sieved through a 4-mm-diameter screen and manually homogenized. Mesocosms were filled with soil to a level $10 \mathrm{~cm}$ below the top. The volume of soil was approximately 13.3 L in each mesocosm. Mesocosms were assigned to one of four treatments: i) control ii) earthworms iii) manure iv) earthworm and manure (Table 1).

Cattle manure samples also were collected from the Reedsville Research Farm the same day as soil samples. Manure pats were sampled two weeks following removal of cattle from grazed pasture plots (plots 15 and 16, Appendix II). This area (approx. 1 ha) was grazed as one paddock by eight cows and eight calves for seven days. Pats were sampled with a spade and placed in large plastic bags and transported back to the lab on ice where samples were stored at $4^{\circ} \mathrm{C}$ until the following day. Manure was sieved through a 4-mm-diameter screen and manually homogenized. To standardize manure addition to mesocosms, manure was packed into 100-mm-diameter Petri dishes and brought to approximately $100 \mathrm{~g}$ wet weight. Plates were inverted and manure placed on the soil surface of two mesocosm systems. Three simulated manure pats were added to each mesocosm that received manure.

Lumbricus terrestris earthworms were obtained from a commercial distributor (DMF Baits, Waterford, MI). Three earthworms picked randomly from each batch of 24 were confirmed to be L. terrestris by following an identification key (Dindal, 1990). Only adult earthworms were used as confirmed by the presence of a clitellum. Prior to addition to mesocosms the earthworms were washed three times in sterile distilled water and placed in sterilized 100-mm Petri dishes with sterile filter paper lining the bottom. Earthworms were starved and depurated for a period of $48 \mathrm{hr}$ to remove previous gut 
contents. Following the starvation period, earthworms again were washed three times as before and placed in designated treatments. Forty-five earthworms were added to each of the two mesocosms that were to receive an earthworm treatment. After addition of earthworms and manure mesocosms were kept in the dark at $25^{\circ} \mathrm{C}$ for a period of $120 \mathrm{hr}$ (5 days).

Sampling: Soil, Manure and Casts

Following the incubation period soil, manure and earthworms were removed from the mesocosms. Each simulated manure pat was first removed using sterile forceps and placed in individual sterile bags and stored at $4^{\circ} \mathrm{C}$ until further analysis. Soil from each individual mesocosm was transferred into large sterile plastic bags. Forty-five earthworms were recovered from each treatment and divided into three groups of fifteen. Individual earthworms were washed three times in sterile distilled water and placed in sterile 100-mm Petri dishes with sterile filter paper. Earthworm casts were collected from Petri dishes every few hours and stored at $4^{\circ} \mathrm{C}$ until further analysis. Cast material was pooled from each of the three groups of each treatment. Soil was then manually homogenized, three separate samples (200 g sample $\left.{ }^{-1}\right)$ were taken from each treatment and placed in sterile bags and stored at $4^{\circ} \mathrm{C}$ until further analysis.

\section{Heterotrophic Plate Counts}

Heterotrophic bacteria from soil, cast and manure samples were quantified with a standard plate count method (Zuberer, 1994). Heterotrophic plate count data obtained for each of the three samples of each material / treatment combination. Samples $(1 \mathrm{~g})$ were 
diluted (1/100 dilution) in 1X Winogradsky Salt solution (WSS) $(99 \mathrm{ml})$ and shaken vigorously (100 reps) to disperse bacterial cells. The solution was then serially diluted $(1 / 10)$ to obtain a $10^{-5}, 10^{-6}, 10^{-7}$ dilution for soil, cast and manure samples, respectively. A $0.1 \mathrm{ml}$ sample from dilutions $10^{-3}$ to $10^{-5}$ was spread on the surface of R2A medium (Ingredients $\mathrm{L}^{-1}: 0.5 \mathrm{~g}$ bacto yeast extract; $0.5 \mathrm{~g}$ bacto proteose peptone no. $3 ; 0.5 \mathrm{~g}$ bacto casamino acids; $0.5 \mathrm{~g}$ bacto dextrose; $0.5 \mathrm{~g}$ soluble starch; $0.3 \mathrm{~g}$ sodium pyruvate $\left(\mathrm{CH}_{3} \mathrm{COCO}_{2} \mathrm{Na}\right) ; 0.3 \mathrm{~g}$ potassium phosphate, dibasic $\left(\mathrm{K}_{2} \mathrm{HPO}_{4}\right) ; 0.05 \mathrm{~g}$ magnesium sulfate $\left(\mathrm{MgSO}_{4}\right) ; 15 \mathrm{~g}$ bacto agar) (Difco, Detroit, MI) $(100 \mathrm{~mm})(3 \mathrm{reps})(\mathrm{n}=9)$. Dilutions of $10^{-4}$ to $10^{-6}$ were used for cast samples while $10^{-5}$ to $10^{-7}$ dilutions were used for manure samples. After incubating for 14 days at $25^{\circ} \mathrm{C}$ the number of colony forming units (CFU's g ${ }^{-1}$ material $^{-1}$ (dry weight)) in each replicate of a sample was determined. Plates were only counted that had between 30 and 300 CFU's and data was logtransformed to obtain geometric means.

Community Level Physiological Profiles - BIOLOG ${ }^{\circledR}$

The capability of soil microbial communities to utilize a variety of carbon sources was assessed using BIOLOG ${ }^{\circledR}$ ECO MicroPlates ${ }^{\mathrm{TM}}$ (Biolog Inc., Hayward, CA) which contain triplicate wells of 31 carbon sources useful for soil community analysis. Three replicate samples ( $1 \mathrm{~g}$ dry wt.) were taken from each of the three samples per material / treatment combination $(n=27)$. Replicate samples were diluted $(1 / 100)$ in WSS and vigorously shaken (100 reps) to homogenize the suspension. This suspension was then further diluted $(1 / 10)$ to obtain a $10^{-3}$ suspension. The $10^{-3}$ dilution was used to inoculate $\left(100 \mu \mathrm{L}_{\text {well }}^{-1}\right)$ BIOLOG $^{\circledR}$ ECO MicroPlates $^{\text {TM }}$. Plates were incubated in the 
dark at $25^{\circ} \mathrm{C}$ for $156 \mathrm{hr}$. The rate utilization of the carbon source was monitored by measuring absorbance at $590 \mathrm{~nm}$. Readings were taken every $12 \mathrm{hr}$. using an automated plate reader (SpectraMAX 340 pc, Molecular Devices, Sunnyvale, CA). Average Well Color Development (AWCD) was calculated as the average optical density across all wells per plate. AWCD was used as an indicator of general microbial activity.

\section{DNA Extraction}

\section{Culture-dependent}

Aliquots $(100 \mu \mathrm{L})$ of the $10^{-2}$ dilution of each material / treatment combination (n =9), described previously for CLPP, were spread onto four replicate R2A agar plates to obtain a $10^{-3}$ dilution (Difco, Detroit, MI). Plates were incubated aerobically for two weeks at $25^{\circ} \mathrm{C}$. Cultured cells were washed and pooled from all four replicate plates using a total of $4 \mathrm{ml}$ of sterile WSS and a sterile inoculating loop. The resulting cell suspensions were vortexed and frozen at $-20^{\circ} \mathrm{C}$ until DNA was extracted. Samples were

thawed, vortexed and DNA was extracted from aliquots of each cell suspension (1.8 ml) using the MoBio Microbial DNA extraction kit (MoBio Labs, Carlsbad, CA) following the manufacturer's protocol.

\section{Culture-independent}

Three replicate samples ( $0.5 \mathrm{~g}$ dry weight) were taken from each of the three samples of each material / treatment combination $(n=9)$. Total DNA was extracted using the MoBio Power Soil DNA Extraction Kit (MoBio Labs, Carlsbad, CA) following manufacturer's protocol. A Fastprep (FP 120-Bio101, Savant Instruments, NY, USA) 
machine was used for the bead-beating step of the procedure. DNA was stored at $-20^{\circ} \mathrm{C}$ until further analysis.

Polymerase Chain Reaction 16S rRNA gene

The variable V3 region of the 16S rRNA gene from the domain Eubacteria was amplified using the PRBA338F primer (5'-ACTCCTACGGGAGGCAGCAG-3') with a GC clamp and the PRUN518R primer (5'-ATTACCGCGGCTGCTGG). The PCR protocol included a 5-minute initial denaturation at $94^{\circ} \mathrm{C}, 30$ cycles of $92^{\circ} \mathrm{C}$ for 30 seconds, $55^{\circ} \mathrm{C}$ for 30 seconds, and $72^{\circ} \mathrm{C}$ for 30 seconds, followed by 7 minutes at $72^{\circ} \mathrm{C}$. The final $50-\mu \mathrm{L}$ reaction mixture contained $1 \times$ PCR buffer (Promega, Madison, WI.), 3.2 $\mu \mathrm{mol}$ of $\mathrm{MgCl}_{2}, 0.8 \mu \mathrm{M}$ of deoxynucleoside triphosphates (Promega, Madison, WI), 2\% bovine serum albumin (Fischer Biotech, Pittsburgh, PA), $0.5 \mu \mathrm{M}$ (each) of forward and reverse primers (IDT DNA, San Diego, CA), 0.5 units of Taq polymerase (Promega, Madison, WI), and 50-200 ng of template DNA. PCR products were pooled, cleaned and concentrated using QIAquick PCR Purification Kit (Qiagen, Valencia, CA), and the amount of PCR product in the samples was determined by running gel electrophoresis on a $1.5 \%$ agarose gel with a mass ladder stained with ethidium bromide. Quantification of DNA in the PCR product was done using volume analysis in Quantity One Software (BioRad, Hercules, CA). 
nirK gene

An approximately 450 b.p. region of the gene that encodes nitrite reductase (nirK) in denitrifying bacteria was amplified using the $\mathrm{F} 1 \mathrm{aCu}$ primer (5'- ATC ATG GTS CTG CCG CG-3') and the R3Cu primer (5'- GCC TCG ATC AGR TTG TGG TT-3') with a GC clamp attached to the 5' end (Hallin and Lindgren, 1999). The PCR protocol included a 2-minute initial denaturation at $94^{\circ} \mathrm{C}, 35$ cycles of $94^{\circ} \mathrm{C}$ for 30 seconds, $67^{\circ} \mathrm{C}$ for 60 seconds, and $72^{\circ} \mathrm{C}$ for 60 seconds, followed by 10 minutes at $72^{\circ} \mathrm{C}$. The final 50 $\mu \mathrm{L}$ reaction mixture contained $1 \times$ PCR buffer (Promega, Madison, WI.), $1.5 \mathrm{mM}$ of $\mathrm{MgCl}_{2}, 200 \mu \mathrm{M}$ of deoxynucleoside triphosphates (Promega, Madison, WI), $400 \mathrm{ng} \mathrm{ml}^{-1}$ bovine serum albumin (Fischer Biotech, Pittsburgh, PA), $1 \mu \mathrm{M}$ (each) of forward and reverse primers (IDT DNA, San Diego, CA), 1.25 units of Taq polymerase (Promega, Madison, WI), and 50-200 ng of template DNA. PCR products were pooled, cleaned and concentrated using QIAquick PCR Purification Kit (Qiagen, Valencia, CA), and the amount of PCR product in the samples was determined by running gel electrophoresis on a $1.5 \%$ agarose gel with a mass ladder stained with ethidium bromide. Quantification of DNA in the PCR product was done using volume analysis in Quantity One Software (BioRad, Hercules, CA).

Denaturing Gradient Gel Electrophoresis 16S rRNA genes

Approximately $150 \mathrm{ng}$ for CD gels and $100 \mathrm{ng}$ for CI gels of pooled PCR product was loaded into a polyacrylamide gel (8\%) with a 40\% (16.8 g urea; $16 \mathrm{ml}$ formamide $/ 100 \mathrm{ml})$ to $60 \%$ (25.2 $\mathrm{g}$ urea; $24 \mathrm{ml}$ formamide $/ 100 \mathrm{ml})$ denaturing gradient. 
Gels were electrophoresed using the DCode ${ }^{\mathrm{TM}}$ Universal Mutation Detection System (BioRad, Hercules, CA) initially for $4 \mathrm{~min}$ at $200 \mathrm{~V}$ to drive samples into the gel and then voltage was reduced to $50 \mathrm{~V}$ at $60^{\circ} \mathrm{C}$ for $16 \mathrm{hrs}$. Gels were subsequently visualized by silver staining using the protocol of Caetano-Anolles and Gresshoff (1994). The developed gels were then scanned using Hewlett Packard ScanJet 7400c (HewlettPackard Co., Palo Alto, CA) in 600 pixel per inch resolution and saved in uncompressed Tiff format for further analysis.

nirK genes

Approximately $125 \mathrm{ng}$ for CD gels and $100 \mathrm{ng}$ for CI gels of pooled PCR product was loaded into a polyacrylamide gel (6\%) with a 50\% (21 g urea; $20 \mathrm{ml}$ formamide/100 $\mathrm{ml}$ ) to $70 \%$ (29.4 g urea; $28 \mathrm{ml}$ formamide/100 ml) denaturing gradient. Gels were electrophoresed using the DCode ${ }^{\mathrm{TM}}$ Universal Mutation Detection System (BioRad, Hercules, CA) initially for $4 \mathrm{~min}$ at $200 \mathrm{~V}$ to drive samples into the gel and then voltage was reduced to $50 \mathrm{~V}$ at $60^{\circ} \mathrm{C}$ for $18 \mathrm{hr}$. Gels were subsequently visualized by silver staining using the protocol of Caetano-Anolles and Gresshoff (1994). The developed gels were then scanned using Hewlett Packard ScanJet 7400c (Hewlett-Packard Co., Palo Alto, CA) in 600 pixel per inch resolution and saved in uncompressed Tiff format for further analysis. 


\section{Data Analysis}

\section{Community Level Physiological Profiles - BIOLOG ${ }^{\circledR}$}

Statistical analyses were performed using SAS Statistical Software (SAS Institute Inc., Cary, NC). BIOLOG ${ }^{\circledR}$ ECO MicroPlates ${ }^{\mathrm{TM}}$ plates were evaluated using Proc GLM with LSMeans and the tdiff option using a double nested analysis of variance (Nested ANOVA), where the values for each of the three replicate per plate were nested within the appropriate sample. Samples were nested within the appropriate treatments. The type III error term was used to test significance based on a $\mathrm{P}$ value of less than or equal to 0.05. A few plates inoculated with soil exhibited anomalous color development and were removed from further analyses because they appeared defective. These plates had very low AWCD and did not follow the color development exhibited by other plates. For BIOLOG $^{\circledR}$ ECO MicroPlates ${ }^{\mathrm{TM}}$ total well color development (TWCD) was calculated as the sum of absorbance values. Average well color development (AWCD) took the mean for those 31 absorbance values. Substrate diversity $(H)$ was calculated as $H=-\sum$ pi lnpi, where pi is the proportion (substrate absorbance divided by TWCD) of total microbial activity on a particular carbon source. Substrate richness (S) was calculated from the total number of wells with absorbance values greater than 0.25 . Substrate richness per guild was calculated from the number of wells with absorbance values greater than 0.25 within each guild. Substrate evenness (E) was calculated as $E=H / \ln (S)$. Principal component analysis (PCA) was done on normalized data obtained by dividing each substrate absorbance value by the AWCD (Garland and Mills, 1991). Pearson's correlation was used to assess correlations between principal components and AWCD of each substrate. 


\section{Denaturing Gradient Gel Electrophoresis}

DGGE gels were analyzed using Quantity One gel analysis software (BioRad, Hercules, CA). Analysis of the profiles was done by setting the background subtraction at 15 using a rolling disk method. Bands were manually picked based on the intensity profile for each lane. Bands that produced intensity peaks that were sharp and defined and greater than the base intensity value $(0.05)$ were considered to be bands. Unweighted pair-group method with arithmetic mean (UPGMA) dendrograms were generated in Quantity One using the Dice similarity index. Bootstrap analysis (1,000 replications) was done using DGGEstat (Van Hannen, 2005). Sorenson similarity index based on the presence/absence of bands was used for analysis of similarity (ANOSIM) test and ordination of data via multidimensional scaling (MDS). The Sorenson similarity index is analogous to the Bray-Curtis index when simple binary (presence/absence) data are used.

The result of MDS ordination is a plot where the position of each sample is determined by its distance from all other points in the analysis. An analysis of similarity ANOSIM routine was used to examine statistical significance between samples.

ANOSIM tests the null hypothesis that the average rank similarity between objects within a group is the same as the average rank similarity between objects between groups. ANOSIM is based on the rank similarities between samples in the similarity matrix and produces a test statistic $\mathrm{R}$ which can range from -1 to 1 . Objects that are more dissimilar between groups than within groups will be indicated by an R statistic greater than 0 . An $\mathrm{R}$ value of 0 indicates the null hypothesis is true. A level of significance $P$ value also is produced for the analysis. ANOSIM involves a test based on the permutations of all 
samples and replicate samples and is free from any assumptions of normality, but not from the assumption of equal within-group dispersion (Rees et al., 2004).

\section{Heterotrophic Plate Counts}

Statistical analyses were performed using SAS Statistical Software (SAS Institute Inc., Cary, NC). Log-transformed plate count data were evaluated using Proc GLM with LSMeans and the tdiff option using a nested analysis of variance (Nested ANOVA), where the geometric mean CFU values of 3 replicate plates for each samples were nested with the appropriate treatment. The type III error term was used to test significance based on a $\mathrm{P}$ value of less than or equal to 0.05 . 


\section{RESULTS}

Preliminary Observations and Experimental Design

A preliminary feasibility study was performed using mesocosms constructed to contain various combinations of pasture soil, cattle manure, and earthworms (Appendix I A, B). Earthworms rapidly established an extensive burrow system within the mesocosms and by visual estimate consumed greater than $50 \%$ of the added manure within a five day incubation period. Samples were conveniently recovered from the mesocosms for laboratory measurements such as enumeration of heterotrophic bacteria, CLPP, and DGGE analyses performed on soils and earthworm casts. Preliminary results from all analyses suggested that bacterial numbers, functional diversity, and genetic fingerprints changed after exposure of soils to cattle manure in combination with earthworms (Appendix I C, D, E, F, G, H). Based on these preliminary observations a replicated experiment was performed employing larger mesocosms (Figure 1) to investigate the impact of earthworm feeding behavior on soil bacterial communities. A summary flow sheet schematic of the experiment is presented in Figure 2.

\section{Heterotrophic Plate Counts}

Soil, earthworm casts, and manure were recovered from the various treatments (Table 1) and heterotrophic bacterial enumerations performed by spread plating onto R2A medium (Table 2). Counts were analyzed using a nested ANOVA and geometric treatment means separated using Tukey's HSD procedure $(\mathrm{P}<0.05)$. Plate counts ranged from 10.28 to 6.97 and were significantly greatest in manure, decreased in earthworm casts, followed by bulk soil. Numbers of bacteria in casts recovered from worms feeding 
on manure were significantly greater than those feeding on soil alone. In the former case, numbers in casts were lower than those obtained directly from manure; in the latter case, numbers were significantly higher than those obtained directly from soil.

\section{Community Level Physiological Profiles}

Functional diversity indices are presented in Table 3. Diversity indicies were analyzed using a double-nested ANOVA and treatment means separated using Tukey's HSD procedure $(\mathrm{P}<0.05)$. Functional diversity indicies were significantly lower in unamended control soil compared with all other samples (Table 3). Intermediate values generally were observed in soil containing worms and in the resultant cast material obtained from worms feeding only on soil. The highest values generally were observed from soil containing worms feeding on manure, cast materials from these worms, and samples obtained directly from manure. Richness values, calculated as the mean number of positively utilized substrates, ranged from 21 to 28 and follow the above trend. Substrates within BIOLOG ${ }^{\circledR}$ ECO MicroPlates ${ }^{\mathrm{TM}}$ can be divided into six substrate guilds (carbohydrates, carboxylic acids, polymers, amino acids, amines/amides, and a miscellaneous category). Table 4 presents mean richness values separated by substrate guild. Richness was generally lowest in control soil and greatest in manure samples for the carbohydrate, polymer, amines/amides, and miscellaneous guilds. No significant differences between treatments were observed for the carboxylic acid and amino acid guilds. 
Principal component analysis (PCA) used to explore multivariate BIOLOG $^{\circledR}$ ECO MicroPlates ${ }^{\mathrm{TM}}$ data is an ordination technique used to arrange multidimensional space into a low-dimensional space such that similar samples are close together and dissimilar samples are far apart. PCA based on adjusted average well color development is presented in Figure 3. Ordination using PCA resulted in distinct separations between treatments. Unamended control soil was well separated from all other treatments along the first principal component axis ( $\mathrm{PC} 1)$, followed by soil treated only with manure and soil treated only with worms. The remaining treatments were separated along the second principal component axis (PC 2). Soil with earthworms fed manure grouped closely with casts from earthworms fed only soil. Casts from earthworms fed manure grouped closely with both remaining manure treatments. Forty four percent of the total observed variation in data was accounted for by the first two principal components (PC $1=26 \%, \mathrm{PC} 2=$ 18\%). PC 1 was most positively correlated with pyruvic acid methyl ester $(r=0.907)$, Dmannitol $(\mathrm{r}=0.875)$ and, D-galactonic acid-y-lactone $(\mathrm{r}=0.770)$; and most negatively correlated with D-malic acid $(r=-0.602)$, D-xylose $(r=-0.534)$ and, $x$-D-lactose $(r=$ $0.525)$. PC 2 was most positively correlated with 4-hydroxy benzoic acid $(\mathrm{r}=0.827)$, Lphenylalanine $(\mathrm{r}=0.824)$ and, Tween $40(\mathrm{r}=0.813)$; and most negatively correlated with $\mathrm{x}$-D-lactose $(\mathrm{r}=-0.656), \mathrm{D}, \mathrm{L}-\mathrm{x}$-glycerol phosphate $(\mathrm{r}=-0.554)$ and, D-galactonic acid $\mathrm{y}$ lactone $(\mathrm{r}=-0.530)$. 
Denaturing Gradient Gel Electrophoresis

16S rRNA gene: Comparison of CD DGGE and CI DGGE bacterial fingerprints

Fingerprints of bacterial community structure were constructed using PCR amplicons of bacterial $16 \mathrm{~S}$ rRNA genes separated by denaturing gradient gel electrophoresis. Both a culture-dependent and a culture-independent DGGE (CD DGGE and CI DGGE) method were used to examine untreated pasture soil; soil treated with manure; pasture soil that contained L. terrestris feeding on soil or a soil manure mixture; and L. terrestris casts obtained from earthworms feeding on soil or a soil manure mixture. Limited space on the DGGE gels precluded the inclusion of manure-alone samples. CD and CI derived PCR amplicons of bacterial 16S rRNA were separated on a single DGGE gel to directly compare the methods (Figure 4a). In order to fit all samples onto a single DGGE gel this experiment utilized a single replicate of each treatment composed of nine pooled PCR reactions.

Dice similarity coefficients were calculated and the unweighted pair-group method with arithmetic mean (UPGMA) was used to generate dendrograms for examination of clustering within community fingerprints (Figure 4b). CD and CI community fingerprints were highly dissimilar (20\% similarity) resulting in two wellseparated clusters. These data suggest that the two methods characterize a distinctly different segment of the soil bacterial community. Within each cluster separated by method, L. terrestris casts were distinctly dissimilar from all soil treatments ( $58 \%$ and $41 \%$ similarity for $\mathrm{CD}$ and $\mathrm{CI}$, respectively). Bacterial communities in cast materials varied according to the worm's food source (67\% and $66 \%$ similarity, for CD and CI respectively). Differences in community fingerprints between soil treatments were less 
distinct, regardless of methodology. Control soils and those receiving only worms tended to cluster distinctly from soils receiving manure treatments.

Analysis of similarity (ANOSIM) derived from Sorenson's similarity values established that highly significant differences existed between community fingerprints. The ANOSIM $\mathrm{R}$ value was $\mathrm{R}=0.95(\mathrm{P}<0.001)$ for the combined $\mathrm{CD}$ and $\mathrm{CI} \mathrm{DGGE}$ fingerprint. Differences in similarity data also were explored using non-metric Multidimensional Scaling (MDS). The large separation between CD and CI data (Figure 5) supported the clustering previously observed with UPGMA and indicates that different bacterial communities were detected by the two methods. Earthworm casts separated from all soil treatments for CI samples but not CD samples. No clear separation between any material or treatment combination was observed when $\mathrm{CD}$ profiles were analyzed via MDS.

The number of bands observed in the combined CI and CD DGGE gel are presented in Table 5, as are the number of distinct bands unique to each treatment. The total number of bands resolved using both the $\mathrm{CD}$ and $\mathrm{CI}$ approach were similar. $\mathrm{CD}$ gel analysis resulted in 74 total bands, with 20 unique to soil treatments and 18 unique to earthworm cast samples; CI analysis resulted in 61 total bands, with 16 unique to soil treatments and 26 unique to earthworm casts. CD and CI analysis each resulted in 9 bands unique to earthworm cast with manure; the greatest number of unique bands compared to all other treatments. 


\section{S rRNA gene: Individual CD DGGE and CI DGGE bacterial fingerprints}

In separate analyses, CD and CI 16S amplicons were separated on individual DGGE gels (Figure 6a and 8a). In these analyses, there were two replicate lanes per treatment for each material (soil and cast). These lanes were composed of three pooled PCR reactions that were amplified from three sub-samples of each of the three main samples. The general trends previously observed in the combined $\mathrm{CD}$ and $\mathrm{CI}$ analysis (Figure 4a) were comparable to results obtained on these separate DGGE gels employing increased replication. The greatest dissimilarity again was observed between microbial communities in earthworm casts and those in soil (Figure $6 \mathrm{~b}$ and $8 \mathrm{~b}$ ). The similarities between these clusters were $46 \%$ and $27 \%$ in CD DGGE and CI DGGE, respectively. Bacterial communities in cast materials again varied according to the worm's food source. Soil-fed and manure-fed earthworm casts were $64 \%(\mathrm{CD})$ and $74 \%(\mathrm{CI})$ similar. Not previously observed, UPGMA cluster analysis separated soil with earthworms feeding on manure from other soil treatments (CD DGGE, 68\% similarity; CI DGGE, $70 \%$ similarity). ANOSIM R values were as follows: $\mathrm{R}=0.93(\mathrm{P}<0.001)$ for $\mathrm{CD}-\mathrm{DGGE}$ fingerprint; $\mathrm{R}=0.89(\mathrm{P}<0.001)$ for $\mathrm{CI} \mathrm{DGGE}$ fingerprint. Ordination plots clearly separated earthworm casts from soil treatments in both CD DGGE and CI DGGE profiles (Figure 7 and 9). MDS analysis of the CD DGGE profile resulted in a significant separation between earthworm casts with manure and earthworm casts without manure. A different pattern to that from previous data was observed in the soil treatments. A small separation was observed between soils containing both earthworms and manure from other CD DGGE treatments. No separation of soil treatments was observed in the CI DGGE analysis. 


\section{DGGE: nirK gene}

A parallel set of DGGE analyses to those described above for the 16S rRNA gene were performed using PCR amplicons derived from the nirK gene. Unlike the 16S rRNA gene which is universally present in all bacteria, nirK is a functional gene coding for a copper-containing nitrite reductase present in a subset of the denitrifying bacteria.

Denitrification activity is known to be stimulated by the presence of earthworms (Horn et al., 2003) therefore fingerprinting populations of these bacteria might provide a more sensitive indicator of bacterial population shifts due to earthworm feeding behavior. A combined $\mathrm{CD} / \mathrm{CI}$ as well individual $\mathrm{CD}$ and CI DGGE gels were constructed for nirK using similar treatments and the same replication schemes reported for the $16 \mathrm{~S}$ gels (Figure 10a, 12a, 14a). One nirK DGGE gel (Figure 10) did not include a control soil or soil plus worms treatment due to the inability to PCR amplify nirK from bacterial community DNA extracted from these samples.

Banding patterns of CD and CI derived nirK amplicons were distinctly dissimilar (17\% similarity; Figure 10b). Within these major clusters earthworm casts clearly separated from all soil treatments $(42 \%$ and $66 \%$ similarity, CD and CI analysis, respectively). ANOSIM derived from Sorenson's similarity values confirmed that significant differences existed between nirK community fingerprints. ANOSIM R value was $\mathrm{R}=1(\mathrm{P}<0.001)$ for the combined $\mathrm{CI}$ and CD DGGE fingerprint. MDS analysis (Figure 11) separated earthworm casts from all soil treatments for CD samples but not CI samples. Little separation occurred between CI treatments or materials. No separations in CD soil treatments were evident. Fewer total bands were produced using the nirK 
gene than with the $16 \mathrm{~S}$ rRNA. No substantial differences in total bands or unique bands were evident within a given treatment for the nirK combined gel (Table 6).

With both the individual nirK CD DGGE and CI DGGE gels the greatest dissimilarity was observed between microbial communities in earthworm casts and those in soil samples. The similarities between these clusters were $43 \%$ and $59 \%$ in CD DGGE and CI DGGE, respectively (Figure 12b and 14b). ANOSIM R values were: 0.64 $(\mathrm{P}<0.001)$ for CD DGGE fingerprint; $0.70(\mathrm{P}<0.002)$ for CI DGGE fingerprint. Ordination plots separated microbial communities from earthworm casts versus soil treatments for both CD DGGE and CI DGGE profiles (Figure 13 and 15). A large separation was observed between earthworm casts treatments in the CD analysis. In the CI DGGE experiment a small separation was observed between soil with earthworms feeding on manure versus other treatments. 


\section{DISCUSSION}

Ingestion, digestion, and excretion of soil or manure by L. terrestris changed the number of heterotrophic bacteria detected in the resultant cast material compared with the original food source. Numbers of bacteria detected in casts obtained from manurefeeding worms were significantly lower than in the original manure. Numbers of bacteria in casts obtained from soil-feeding worms were significantly higher than in the original soil.

As a food source passes through the earthworm alimentary tract, numbers of bacteria present in the original material can be increased or decreased. This suggests that deposition of earthworm casts within the soil profile should modify numbers of bacteria present. However, in the present study no significant differences in bacterial numbers were found among the various soil treatments. This might be due to the relatively short experimental incubation period in the presence of worms resulting in a relatively small volume of cast material, or could be due to a dilution artifact from recovery and mixing of the all soil present in the mesocosm prior to further analyses. Similar data were reported by Pedersen and Hendriksen (1993) who also observed differential survival and growth of various gram negative bacteria within the earthworm alimentary canal. Several other studies have reported increased microbial numbers in the earthworm gut compared to bulk soil (Daniel and Anderson, 1992; Edwards and Fletcher, 1988; Kristufek et al., 1992; Parle, 1963; Schonholzer et al., 1999; Tomlin et al., 1995; Wolter and Scheu, 1999). Devliegher and Verstraete (1997) found greater numbers of fluorescent pseudomonads associated with casts of L. terrestris compared to bulk soil. High 
concentrations of organic residues and easily-degradable mucopolysaccharides can provide energy rich substrates supporting microbial growth within the earthworm digestive tract (Fischer et al., 1997). Ingested microorganisms must also endure digestive enzymes and microaerophilic and/or anaerobic conditions, which could inhibit microbial growth or lead to cell death. In theory, the alimentary canal of the earthworm may inhibit the growth of some bacterial populations, favor the growth of others, while allowing others to pass unaffected. As a result, earthworms may selectively transport and disseminate specific microbial groups through the soil by their burrowing behavior (Thorpe et al., 1996), thereby modifying soil bacterial community structure. Image analyses of stained thin soil sections recently have been used to directly demonstrate the presence of enhanced microbial numbers associated with earthworm casts in upper horizons of upland grassland soils (Bruneau et al., 2005)

Garland and Mills (1991) first used BIOLOG ${ }^{\circledR}$ microtitre plates to measure community level physiological profiles (CLPPs) from the number and types of carbon substrates used by the heterotrophic bacterial community. BIOLOG ${ }^{\circledR}$ ECO MicroPlates ${ }^{\mathrm{TM}}$ were developed for environmental studies and contain three replicate sets of 31 carbon substrates relevant to the growth of soil microorganisms (Campbell et al., 1997). Inoculation of samples into BIOLOG ${ }^{\circledR}$ ECO MiroPlates ${ }^{\mathrm{TM}}$ produces communitylevel physiological profiles (CLPP) of potential microbial C-source utilization. Limitations to CLPP measurements have been examined extensively (Garland, 1997, Konopka et al., 1998, Preston-Mafham et al., 2002). The assay primarily characterizes metabolically active copiotrophic bacteria, therefore correlations with actual in situ carbon utilization are limited. However, the assay allows rapid characterization of 
relative changes in microbial functional diversity and is complementary to molecular techniques for community characterizations (Singh et al., 2006). Previous studies have been able to ascertain shifts in the physiological processes of soil microbial communities due to soil type (Widmer et al. 2001; Girvan et al. 2003), amendment with crop residues and urine (Sharma et al. 1998; Williams et al. 2000; Bending et al. 2002; Malosso et al. 2005), and crop species and crop rotation (Bending et al. 2000; Grayston et al., 2004, Meithling et al. 2000, Singh et al., 2006).

Only one previous study has examined CLPP patterns in earthworm casts. Aira et al. (2006), reported that after gut transit through the earthworm Eudrilus eugeniae, the microbial CLPP profiles obtained from a food source comprised of pig manure were clearly differentiated from resultant earthworm casts. Functional diversity indicies were higher in cast material, despite reduced overall respiration, biochemical enzyme activities, and $\mathrm{C}$ and $\mathrm{N}$ concentrations compared with the pig slurry.

In the present study, statistically significant differences were detected between treatments using functional diversity indices and clear separation of treatments by PCA were observed. In contrast to observations by Aira et al. (2006), diversity indicies generally were lower in casts compared with cattle manure, but were higher than values observed in soil samples. Casts were separated from all soil samples except soil with earthworms fed manure. Casts from earthworms fed manure clustered most closely with manure samples.

As demonstrated by PCA, digestion of unamended soil by earthworms changed the microbial physiological profile. In contrast, digestion of manure-amended soil resulted in CLPP's more similar to the original manure food source. This difference is 
likely attributed to the available organic carbon in the two materials. Manure bacteria in the earthworm gut probably experienced little change in carbon availability. Soil bacteria probably experience a more carbon and nutrient rich environment in the earthworm gut perhaps leading to activation of dormant and/or endospore-forming bacteria or enrichment of selected microbial groups. Resuscitation of bacteria would prime them for rapid growth within BIOLOG $^{\circledR}$ ECO MicroPlates ${ }^{\mathrm{TM}}$ (Horn et al., 2003).

There was a large separation in PCA ordination between the soil control and all other soil treatments. The largest differences observed in soil samples occurred when earthworms feeding on manure were present. Earthworms in soil, especially when a microbe rich food source such as manure is present, appear to affect the dominant microbial physiological types enriched and detected in the $\mathrm{BIOLOG}^{\circledR}$ ECO MicroPlates ${ }^{\mathrm{TM}}$ assay. This does not automatically imply long-term changes in soil physiological processes leading to changes in soil fertility or quality. Broad functional redundancy of soil microorganisms results in the ability of multiple taxa to carry out the same physiological function (Langenheder et al., 2006). Therefore large-scale changes in microbial community composition may be necessary to induce shifts in the physiological activities that dominate soil microbial processes.

Muyzer et al. (1993) used denaturing gradient gel electrophoresis (DGGE) as a method to fingerprint the genetic diversity of environmental bacterial communities (Ovreas and Torsvik, 1998; Bruns et al., 1999; Smalla et al., 2001; McCaig et al., 2001; Girvan et al., 2003; Nicol et al., 2003; Salles et al., 2004). DGGE separates PCR amplicons of a target gene based on their percent GC content in a polyacrylamide gel containing a gradient of urea and formamide. DGGE fingerprints of soil microbial 
communities often result in complex banding patterns, which are hard to resolve and compare, particularly when CI DGGE of the 16S rRNA gene is employed (Ovreas and Torsvik, 1998; Nakatsu et al., 2000). CD DGGE is an alternative method that may provide simpler, more distinct fingerprints. Ellis et al. (2003) suggested that profiles of culturable bacteria may provide a sensitive ecological indicator due to their rapid response to environmental change. Duineveld et al. (1998) previously demonstrated that CI DGGE and CD DGGE profiles of soil microbial community 16S rRNA genes produced dissimilar community fingerprints. Gram-positive bacteria and Proteobacteria are the predominant bacteria reported using culture-dependent methods (Dunbar et al., 1999). Members of the Acidobacteria and Verrucomicrobia are commonly detected using culture-independent methods (Hugenholtz et al., 1998; Barns et al., 1999).

In the present study, comparison on the same gel of CD DGGE and CI DGGE 16S rRNA fingerprints resulted in broad separation by methodology. Similar patterns of treatment separation were observed within each method. Cast microbial communities always were distinctly dissimilar from soil. Presence of manure in a cast or soil treatment generally resulted in distinct fingerprints compared with unamended samples. Microbial communities of earthworm guts/casts are derived from their food source but are modified within the earthworm due to different physiological conditions. Using terminal restriction length polymorphisms (T-RFLPs) of 16S rRNA genes, Egert et al. (2004) found significant differences in community profiles between soil and casts of $L$. terrestris. In contrast, work by Furlong et al. (2002) suggested similar community composition but increased abundance of phyla such as $y$-Proteobacteria in casts compared to soils inhabited by L. rubellus. 
Other soil-feeding invertebrates such as humivorous beetle larvae (Egert et al., 2003) and soil feeding termites (Schmitt-Wagner et al., 2003) possess characteristic indigenous microbial communities. Previous studies have suggested that earthworms also posses an indigenous bacterial population (Jolly et al., 1993; Toyota and Kimura, 2000), however more recent studies refute these findings. Analysis of $16 \mathrm{~S}$ rRNA genes in earthworm guts and casts suggest that the microbial communities in the earthworm gut is largely food derived (Furlong et al., 2002; Egert et al., 2004). Unique bands (bands not found in any other treatment) in DGGE profiles generated from earthworm casts could represent bacteria specific to the earthworm's alimentary canal. Earthworms used in this study were obtained from a commercial distributor and were kept in an artificial bedding material which could be a source of non-soil bacteria. Earthworms were depurated prior to use, however some of the original non-soil bacteria may have remained in earthworms digestive tract. If these bacteria persisted during soil consumption and passed through the digestive tract then perhaps they would be detectable by DGGE in cast materials. Enrichment and growth of soil bacteria within the earthworm gut to levels detectable by DGGE could provide an alternative explanation for the appearance of unique bands in cast material.

Earthworms fed both manure produced casts distinct from those fed soil alone. Disappearance of bands after passage through the earthworm digestive system suggests that some bacteria were consumed and digested rather than passing through unharmed. Bands present in soil but not in earthworm casts could result from selective grazing (Wolter and Scheu, 1999). It has been suggested that fungi, and protozoa, are the primary source of nutrients for earthworms, while bacteria and algae are less important as 
nutrient resources and are not digested by earthworms (Brown, 1995; Edwards and Bohlen, 1996; Edwards and Fletcher, 1988). The greatest numbers of unique DGGE bands where associated with casts from manure fed worms, most likely due to the preferential feeding of the earthworms on the supplemented manure and associated microorganisms. Egert et al. (2004) found that cast microbial communities that were distinct from soil became divergent from soil communities when earthworms consumed a mixture of soil and leaf litter.

The capacity to denitrify is widely distributed among members of the Proteobacteria which are numerically prevalent in L. terrestris cast material (Fischer et al., 1997). The earthworm gut is an ideal habitat for denitrification: anoxic conditions, high water content, sugars, organic acids, amino acids, nitrate, nitrite, and ammonium are all present in nonlimiting amounts (Horn et al., 2003). The intestines of earthworms have been found to activate ingested denitrifiers and other nitrate-dissimilating bacteria, which may impact nitrogen transformations within soils (Ihssen et al., 2003). Earthworms have a greater capacity to denitrify than bulk soil, producing large amounts of both $\mathrm{N}_{2} \mathrm{O}$ and $\mathrm{N}_{2}$ (Ihssen et al., 2003; Karsten and Drake, 1997; Elliott and Anderson, 1990; Matthies et al., 1999; Horn et al., 2006). Various mechanisms have been proposed to explain differences in denitrification between earthworms, their casts, and bulk soil: $i$ ) the denitrifying community found in casts resulted from a pre-existing community attached to the gut wall (Singleton et al., 2001), ii) digestive processes differentially lysed or stimulated ingested bacteria (Oliver, 1993), iii) selective feeding by earthworms (Wolter and Scheu, 1999), iv) culture-dependent resuscitation of viable but dormant cells (Egert et al., 2003), and v) activation of dormant endospore-forming denitrifying bacteria 
stimulated by availability of sugars and amino acids (Fischer et al., 1995). Fischer et al. (1997) found passage through the gut of L. terrestris initiated spore germination of Bacillus megaterium, a significant member of the earthworm cast microbial community (Furlong et al., 2002).

Functional genes encoding enzymes involved in the denitrification pathway can be targeted for community fingerprint analyses (Wolsing and Prieme, 2004). PCR primers producing amplicons suitable for DGGE recently have been developed for two genes; nirK and nosZ (Throback et al., 2004). In the present study, denitrifying communities of pasture soil and L. terrestris casts were compared based on nitrite reductase (nirK) genes separated via DGGE. Similarities values from both CD and CI DGGE profiles resulted in significant differences between denitrifying communities of casts and soil. This dissimilarity became more evident when earthworms were fed on manure as an additional food source. These data contrast with the results of Horn et al. (2003) who cloned and sequenced nitrous oxide reductase (nosZ) genes from the gut of the earthworm Aporrectodea caliginosa to characterize denitrifying microbial populations. Results of this phylogenetic study revealed no significant differences between soil and earthworm gut communities, however higher numbers of Pseudomonasrelated denitrifiers occurred in soil compared with the earthworm gut.

Nitrite reductase is a key enzyme in the process of denitrification. Two distinct structural types of dissimilatory nitrite reductases are know: i) a copper-containing enzyme (Cu-Nir) encoded by the nirK gene ii) and a heme c and heme $\mathrm{d}$-containing enzyme ( $\mathrm{cd}_{1}$-Nir) encoded by the nirS gene. Suitable DGGE primers exist only for nirK, therefore the community fingerprints reported in the present study do not universally 
cover the expected diversity of denitrifying bacteria. Numerically important soil denitrifiers such as Pseudomonas fluorescens contain the nirS gene and therefore would not be detected in the current analyses. (Gamble et al., 1977; Coyne et al, 1989). Casts of L. terrestris are reported to contain 100 fold more fluorescent pseudomonads that corresponding untreated soil (Devliegher and Verstraete, 1997).

Treatment differences observed with nirK DGGE were consistent with differences seen with 16S rRNA gene and with CLPP analyses. Previous reports found that physiological (CLPP) and molecular results were qualitatively similar suggesting the two approaches may be reporting on similar members of the microbial community (Crecchio et al., 2004, Grayston et al., 2004, Singh et al., 2006). However, others report a lack of correlation. For example, Perez-Piqueres et al. (2006) saw changes in bacterial T-RFLP fingerprints caused by compost amendments that were not related to changes in CLPP. In the present study similarities between CLPP and DGGE were most apparent in respect to CD DGGE. These two methods may produce qualitatively similar results due to the fact that both methods employ the heterotrophic cultivable fraction of the soil community. The observation that CLPP and DGGE produce analogous results adds strength to the concept that the multiple method approach can be used to better characterize changes in soil microbial communities. 


\section{CONCLUSIONS}

Data suggest that bacterial communities contained in the earthworms food source are modified after ingestion; however resultant changes in the soil bacterial community primarily occurred when earthworms consumed a soil manure mixture. Bacterial densities and substrate utilization changed upon digestion and excretion by earthworms, especially when manure was a food source, compared to unamended pasture soil. Molecular fingerprints of two genes (16S rRNA and nirK) also suggested changes in total and denitrifying communities upon ingestion and excretion of soil or manure. The greatest alterations in soil microbial communities generally were observed when earthworms consumed manure as a food source. Grazing beef cattle introduce exogenous bacteria to the soil environment. As earthworms move through the soil depositing cast material they translocate microorganisms that otherwise would be spatially limited to the area in which the manure was deposited. Whether these bacteria are able to persist and overcome the indigenous soil population or influence inherent nutrient cycles will require longer-term study.

In future studies it would be worthwhile to further characterize the microbial communities of earthworm casts through sequencing of unique and common DGGE bands to better understand how the digestive process of earthworms specifically changes microbial populations. Identifying specific organisms that are positively or negatively regulated by earthworms could provide insight into the properties of the earthworm alimentary canal that change the soil microbial community. Knowledge of the changing members of the soil community coupled with measurements of microbial processes (i.e., enzyme activity, biomass, denitrification and respiration) could provide a better 
understanding of the interactions between soil bacteria and earthworms and their effect on soil quality and fertility. Parallel utilization of the functional genes nosZ and nirS for community fingerprinting should provide additional insights. 
Table 1. Description of the experimental treatments.

\begin{tabular}{|c|c|c|}
\hline Material & Treatment & Description \\
\hline \multirow{4}{*}{ Soil } & Control & Pasture soil that received no treatment \\
\hline & Worm & Pasture soil incubated with $L$. terrestris \\
\hline & Manure & $\begin{array}{l}\text { Pasture soil incubated with manure pats on the soil } \\
\text { surface }\end{array}$ \\
\hline & $\begin{array}{l}\text { Worms }+ \\
\text { Manure }\end{array}$ & $\begin{array}{l}\text { Pasture soil incubated with L. terrestris and manure on } \\
\text { the soil surface }\end{array}$ \\
\hline \multirow[b]{2}{*}{ Cast } & Soil & $\begin{array}{l}\text { L. terrestris casts collected from worms feeding only on } \\
\text { pasture soil (from soil with worms treatment) }\end{array}$ \\
\hline & Manure & $\begin{array}{l}\text { L. terrestris casts collected from worms feeding on } \\
\text { pasture soil and manure (from soil with worms and } \\
\text { manure treatment) }\end{array}$ \\
\hline \multirow{2}{*}{ Manure } & w/out Worms & Manure collected from soil with manure treatment \\
\hline & $\mathrm{w} /$ Worms & $\begin{array}{l}\text { Manure collected from soil with worms and manure } \\
\text { treatment }\end{array}$ \\
\hline
\end{tabular}


Table 2. Heterotrophic plate counts obtained using R2A medium incubated aerobically at $25^{\circ} \mathrm{C}$ for $48 \mathrm{~h}$.

\begin{tabular}{cccc}
\hline Material & Treatment & CFU g $^{-1}$ material $^{\text {a }}$ & \\
\hline \multirow{2}{*}{ Soil } & Control & 7.04 & $\mathrm{a}$ \\
& Earthworms & 6.97 & $\mathrm{a}$ \\
& Manure & 7.04 & $\mathrm{a}$ \\
& Earthworms + Manure & 7.06 & $\mathrm{a}$ \\
\hline Cast & Soil & 8.09 & $\mathrm{~b}$ \\
& Manure & 8.76 & $\mathrm{c}$ \\
\hline Manure & w/out Earthworms & 10.28 & $\mathrm{~d}$ \\
& w/ Earthworms & 10.18 & $\mathrm{~d}$ \\
\hline
\end{tabular}

${ }^{a}$ Geometric mean values $(n=9)$ followed by the same letter are not significantly different $(\mathrm{p}<0.05)$ as determined by Tukey's Studentized Range (HSD) Test). 
Table 3. Bacterial functional diversity indices determined using BIOLOG ${ }^{\circledR}$ ECO MicroPlates $^{\mathrm{TM}}$.

\begin{tabular}{|c|c|c|c|c|c|c|c|c|c|c|c|c|}
\hline \multirow[t]{2}{*}{ Material } & \multirow{2}{*}{$\begin{array}{c}\text { Treatment } \\
\text { Control }\end{array}$} & \multirow{2}{*}{$\frac{\mathbf{n}^{\mathbf{g}}}{21}$} & \multicolumn{2}{|c|}{ TWCD $^{\mathbf{a}}$} & \multicolumn{2}{|c|}{ AWCD $^{b}$} & \multicolumn{2}{|c|}{ Richness $^{c}$} & \multicolumn{2}{|c|}{ Diversity $^{d}$} & \multicolumn{2}{|c|}{ Evenness $^{\mathrm{e}}$} \\
\hline & & & 31.2 & $\mathrm{a}$ & 1.00 & $\mathrm{a}$ & 21 & $\mathrm{a}$ & 2.78 & $\mathrm{a}$ & 0.93 & $\mathrm{a}$ \\
\hline \multirow{3}{*}{ Soil } & Worm & 21 & 34.7 & $b$ & 1.12 & $b$ & 23 & $\mathrm{~b}$ & 3.00 & $b$ & 0.95 & $b$ \\
\hline & Manure & 12 & 42.1 & d & 1.35 & $\mathrm{~d}$ & 24 & $\mathrm{~b}$ & 3.01 & $\mathrm{bc}$ & 0.95 & $\mathrm{~b}$ \\
\hline & Worms + Manure & 21 & 45.0 & e & 1.45 & e & 27 & $\mathrm{c}$ & 3.16 & $\mathrm{~d}$ & 0.96 & $\mathrm{c}$ \\
\hline \multirow{2}{*}{ Cast } & Soil & 27 & 33.3 & $\mathrm{~b}$ & 1.07 & $\mathrm{~b}$ & 24 & $\mathrm{~b}$ & 3.05 & $\mathrm{c}$ & 0.96 & $\mathrm{c}$ \\
\hline & Manure & 27 & 39.0 & $\mathrm{c}$ & 1.25 & $\mathrm{c}$ & 27 & $\mathrm{c}$ & 3.17 & $\mathrm{~d}$ & 0.97 & $\mathrm{c}$ \\
\hline \multirow{2}{*}{ Manure } & w/out Worms & 27 & 38.4 & $\mathrm{c}$ & 1.24 & $\mathrm{c}$ & 28 & $\mathrm{c}$ & 3.20 & $\mathrm{~d}$ & 0.96 & $\mathrm{c}$ \\
\hline & w/ Worms & 27 & 37.8 & $\mathrm{c}$ & 1.22 & $\mathrm{c}$ & 28 & $\mathrm{c}$ & 3.20 & $\mathrm{~d}$ & 0.96 & c \\
\hline ANOVA $^{f}$ & $\mathrm{P}$ value & & \multicolumn{2}{|c|}{$\mathrm{P}<0.01$} & \multicolumn{2}{|c|}{$\mathrm{P}<0.01$} & \multicolumn{2}{|c|}{$\mathrm{P}<0.002$} & \multicolumn{2}{|c|}{$\mathrm{P}<0.005$} & \multicolumn{2}{|c|}{$\mathrm{P}<0.04$} \\
\hline
\end{tabular}

Mean values in each column within a particular treatment followed by the same letter are not significantly different $(\mathrm{P}<0.05)$ as determined by Tukey's Studentized Range (HSD) Test.

${ }^{a}$ Total well color development $($ TWCD $)=$ mean sum of blanked absorbance values.

${ }^{\mathrm{b}}$ Average well color development $(\mathrm{AWCD})=\mathrm{TWCD} / 31$.

${ }^{\mathrm{c}}$ Richness $=$ mean number of wells greater than 0.25 .

${ }^{\mathrm{d}}$ Diversity $=\mathrm{H}=-\Sigma(\mathrm{pi}$ (n) $\ln$ ), where $\mathrm{pi}=$ mean of each absorbance value / TWCD.

${ }^{\mathrm{e}}$ Evenness $=\mathrm{E}=\mathrm{H} / \ln (\mathrm{S})$, where $\mathrm{H}$ is diversity and $\mathrm{S}$ is richness.

${ }^{\mathrm{f}} \mathrm{P}$ values for overall double-nested ANOVA test for substrate guild richness

${ }^{\mathrm{g}}$ Uneven treatment replication is due to unusual well color development in some BIOLOG ${ }^{\circledR}$ Eco plates. These plates were removed from the analysis. 
Table 4. Richness within substrate guilds as determined by utilized substrates within BIOLOG ${ }^{\circledR}$ ECO MicroPlates $^{\mathrm{TM}}$.

\begin{tabular}{|c|c|c|c|c|c|c|c|c|c|c|c|c|c|c|}
\hline \multirow{5}{*}{$\begin{array}{c}\text { Material } \\
\text { Soil }\end{array}$} & \multirow{4}{*}{$\begin{array}{c}\text { Treatment } \\
\text { Control } \\
\text { Earthworms } \\
\text { Manure }\end{array}$} & \multirow{2}{*}{$\frac{\mathbf{n}^{\mathbf{d}}}{21}$} & \multicolumn{2}{|c|}{$\begin{array}{c}\text { Carbohydrates } \\
(7)^{\mathrm{a}} \\
\end{array}$} & \multicolumn{2}{|c|}{$\begin{array}{c}\text { Carboxylic Acids } \\
\text { (9) }\end{array}$} & \multicolumn{2}{|c|}{$\begin{array}{l}\text { Polymers } \\
\text { (4) }\end{array}$} & \multicolumn{2}{|c|}{$\begin{array}{c}\text { Amino Acids } \\
\text { (6) }\end{array}$} & \multicolumn{2}{|c|}{$\begin{array}{c}\text { Amines/Amides } \\
\text { (2) }\end{array}$} & \multicolumn{2}{|c|}{$\begin{array}{l}\text { Misc. }^{b} \\
\text { (3) }\end{array}$} \\
\hline & & & 4.1 & $\mathrm{a}$ & 6.4 & - & 3.1 & $\mathrm{a}$ & 3.9 & - & 1.4 & $\mathrm{ab}$ & 1.9 & $\mathrm{a}$ \\
\hline & & 21 & 4.4 & $\mathrm{a}$ & 7.5 & - & 3.5 & $\mathrm{c}$ & 4.3 & - & 1.2 & $a b$ & 2.3 & $\mathrm{~b}$ \\
\hline & & 12 & 5.0 & $\mathrm{~b}$ & 7.1 & - & 3.7 & $\mathrm{~cd}$ & 4.3 & - & 1.5 & $\mathrm{~b}$ & 2.3 & $\mathrm{~b}$ \\
\hline & Worms + Manure & 21 & 5.4 & $\mathrm{bc}$ & 8.0 & - & 3.9 & $\mathrm{~d}$ & 5.0 & - & 1.9 & $\mathrm{c}$ & 2.6 & $\mathrm{~b}$ \\
\hline \multirow{2}{*}{ Cast } & Soil & 27 & 5.6 & $\mathrm{~cd}$ & 6.4 & - & 3.3 & $a b$ & 4.1 & - & 1.9 & $\mathrm{c}$ & 2.6 & $\mathrm{bc}$ \\
\hline & Manure & 27 & 6.0 & $\mathrm{~d}$ & 7.3 & - & 3.9 & $\mathrm{~d}$ & 4.4 & - & 2.0 & $\mathrm{c}$ & 3.0 & $\mathrm{~d}$ \\
\hline \multirow{2}{*}{ Manure } & w/out Worms & 27 & 7.0 & e & 7.2 & - & 3.9 & $d$ & 4.6 & - & 2.0 & $\mathrm{c}$ & 3.0 & d \\
\hline & w/ Worms & 27 & 6.9 & e & 6.9 & - & 4.0 & $\mathrm{~d}$ & 4.9 & - & 2.0 & $\mathrm{c}$ & 3.0 & $\mathrm{~cd}$ \\
\hline ANOVA $^{c}$ & $\mathrm{P}$ value & & \multicolumn{2}{|c|}{$\mathrm{P}<0.0001$} & \multicolumn{2}{|c|}{$\mathrm{P}<0.1$} & \multicolumn{2}{|c|}{$\mathrm{P}<0.0025$} & \multicolumn{2}{|c|}{$\mathrm{P}<0.2$} & \multicolumn{2}{|c|}{$\mathrm{P}<0.0028$} & \multicolumn{2}{|c|}{$\mathrm{P}<0.0001$} \\
\hline
\end{tabular}

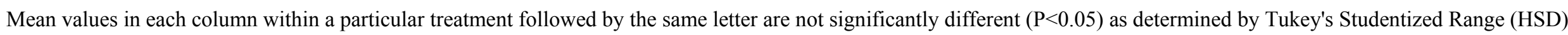
Test.

${ }^{\mathrm{a}}$ Values in parenthesis are number of substrates in each substrate guild.

${ }^{\mathrm{b}}$ Misc. $=$ Miscellaneous

${ }^{\mathrm{c}} \mathrm{P}$ values for overall double-nested ANOVA test for substrate guild richness

${ }^{\mathrm{d}}$ Uneven treatment replication is due to unusual well color development in some BIOLOG ${ }^{\circledR}$ Eco plates. These plates were removed from the analysis. 
Table 5. Total and unique band counts for combined culture dependent and culture independent 16S rRNA DGGE profile (Figure 4a.).

\begin{tabular}{cccccc}
\hline & & \multicolumn{2}{c}{ Total Bands* } & \multicolumn{2}{c}{ Unique Bands** } \\
\hline \multirow{2}{*}{ Material } & Treatment & CD & CI & CD & CI \\
\hline \multirow{3}{*}{ Soil } & Control & 33 & 26 & 1 & 3 \\
& Worm & 38 & 19 & 0 & 0 \\
& Manure & 41 & 17 & 3 & 0 \\
& Worm + Manure & 43 & 21 & 3 & 5 \\
\hline \multirow{2}{*}{ Cast } & Soil & 38 & 33 & 4 & 6 \\
& Manure & 43 & 34 & 9 & 9 \\
\hline \multirow{2}{*}{ Total } & Soil & ND & ND & 20 & 16 \\
& Cast & ND & ND & 18 & 26 \\
& Soil \& Cast & 74 & 61 & 61 & 48 \\
\hline
\end{tabular}

*Total values refer to the sum of all treatments for each material (soil or cast) or the sum of all treatments for both materials (soil and casts)

**Unique bands are defined as bands that are found in only one material/treatment and are not shared with any other material/treatment

$\mathrm{ND}=$ not determined 
Table 6. Total and unique band counts for combined culture dependent and culture independent nirK DGGE profile (Figure 10 a.).

\begin{tabular}{cccccc}
\hline & & \multicolumn{2}{c}{ Total Bands* } & \multicolumn{2}{c}{ Unique Bands** } \\
\hline \multirow{2}{*}{ Material } & Treatment & CD & CI & CD & CI \\
\hline \multirow{3}{*}{ Soil } & Control & 22 & ND & 0 & ND \\
& Worm & 24 & ND & 1 & ND \\
& Manure & 21 & 21 & 0 & 2 \\
& Worm + Manure & 23 & 24 & 0 & 3 \\
\hline \multirow{2}{*}{ Cast } & Soil & 16 & 20 & 1 & 1 \\
& Manure & 21 & 18 & 7 & 0 \\
\hline \multirow{3}{*}{ Total } & Soil & ND & ND & 15 & 10 \\
& Cast & ND & ND & 12 & 5 \\
& Soil \& Cast & 38 & 31 & 33 & 26 \\
\hline
\end{tabular}

*Total values refer to the sum of all treatments for each material (soil or cast) or the sum of all treatments for both materials (soil and casts)

**Unique bands are defined as bands that are found in only one material/treatment and are not shared with any other material/treatment

$\mathrm{ND}=$ not determined 

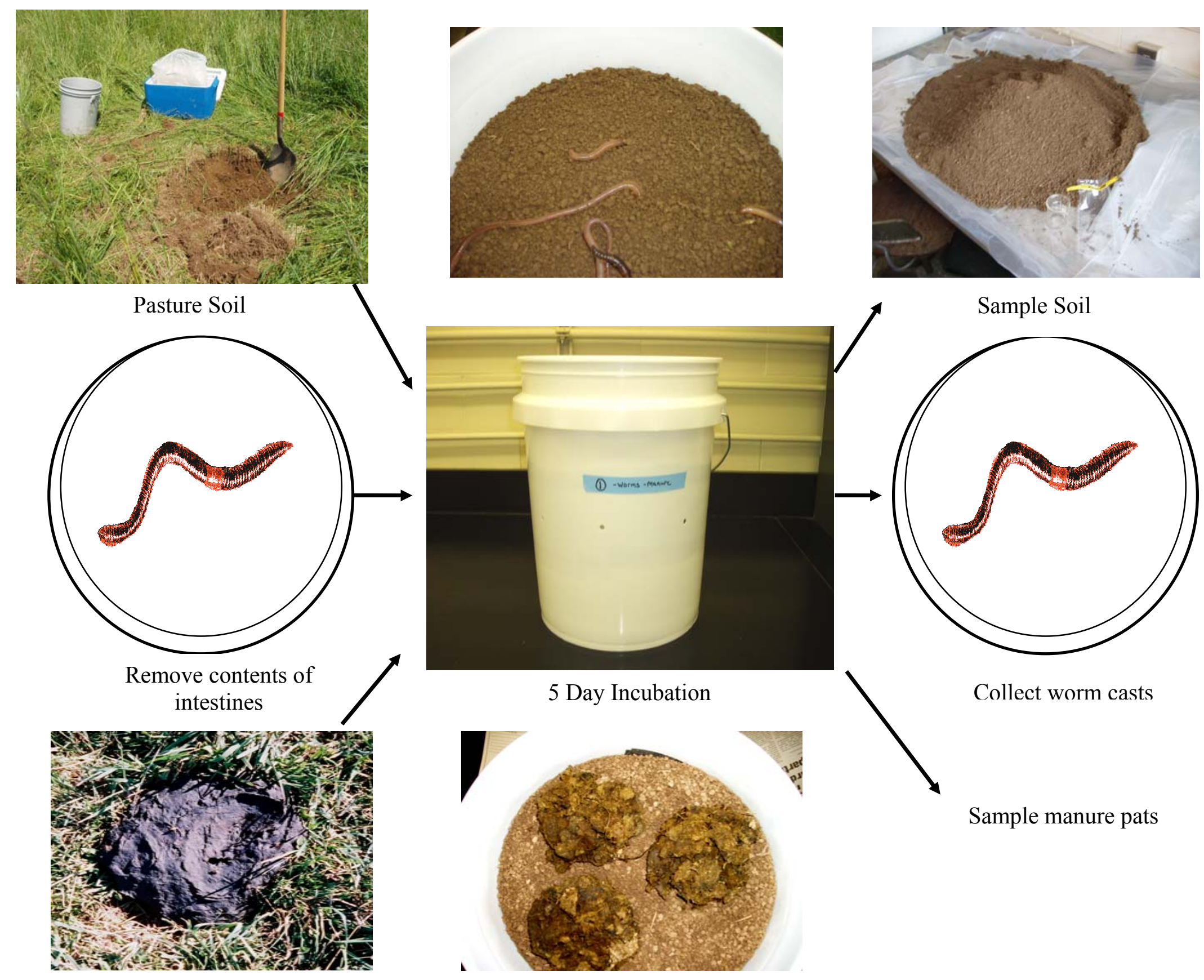

Collect worm casts

Cattle Manure

Figure 1. Depiction of the experimental process. 


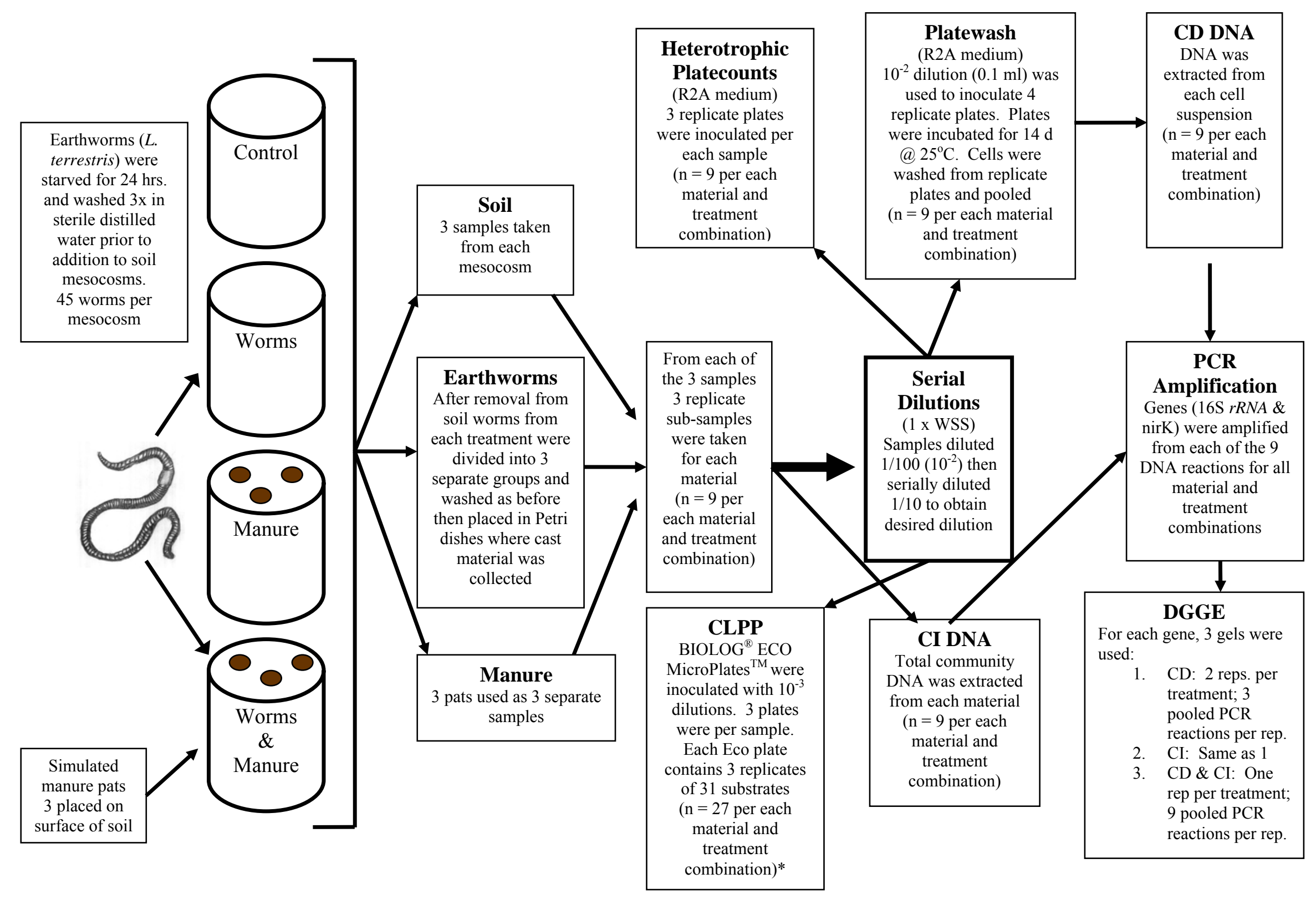

Figure 2. Experiment 2 flow chart. 


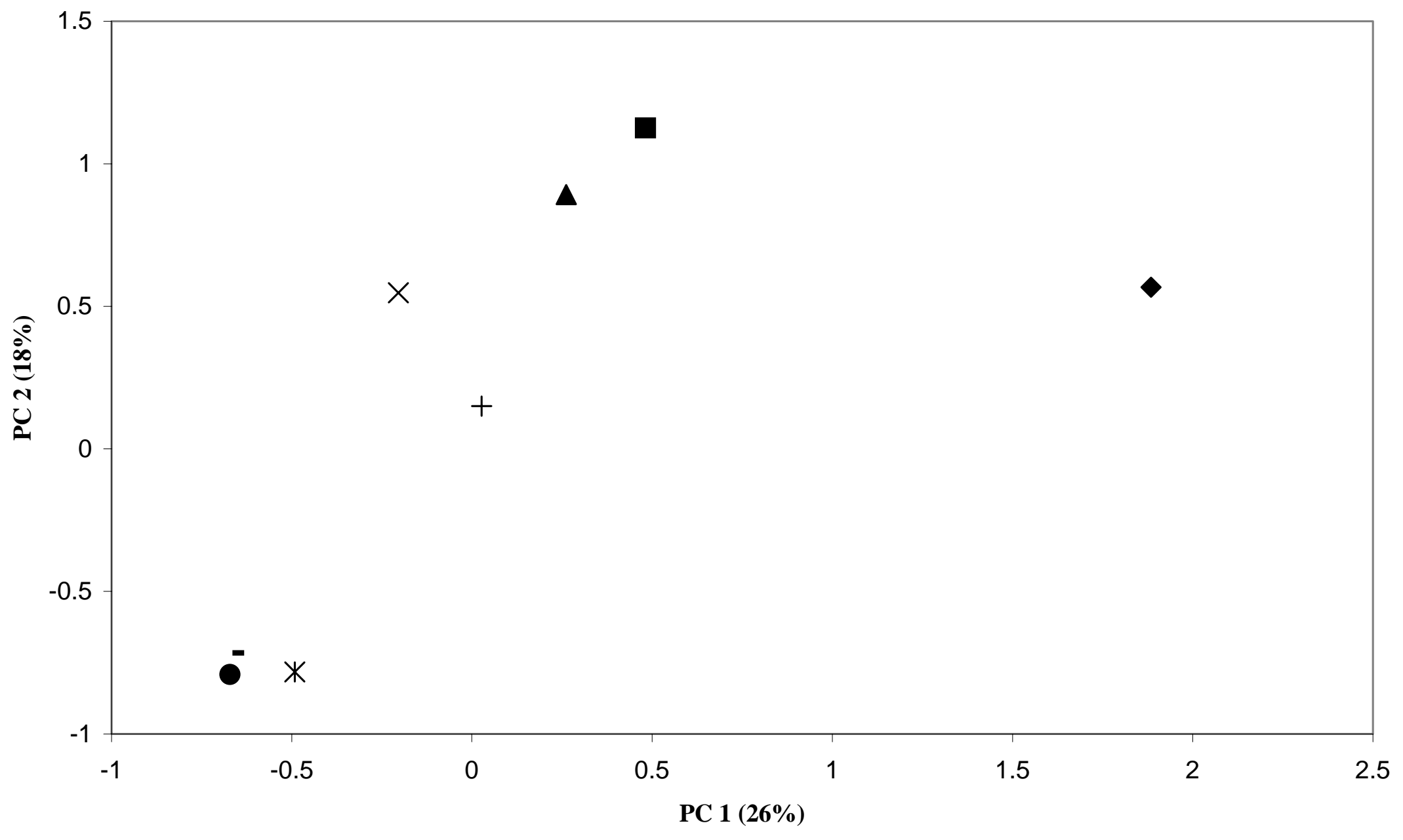

$\bullet$ Soil Control

Soil Worm

$\Delta$ Soil Manure $\quad \times$ Soil Worm Manure $\quad$ X Manure

- Manure Worm

+ Cast

- Cast Manure

Figure 3. Principal component analysis based on normalized well color development (average absorbance value for each substrate divided by AWCD) from BIOLOG ${ }^{\mathbb{B}}$ ECO MicroPlates ${ }^{\mathrm{TM}}$ for pasture soil, L. terrestris casts and manure. Values in parenthesis on the axis indicate the proportion of the total variation accounted for by each principal component. See Table 3 for number of replicates per treatment $(n)$. 
(a)

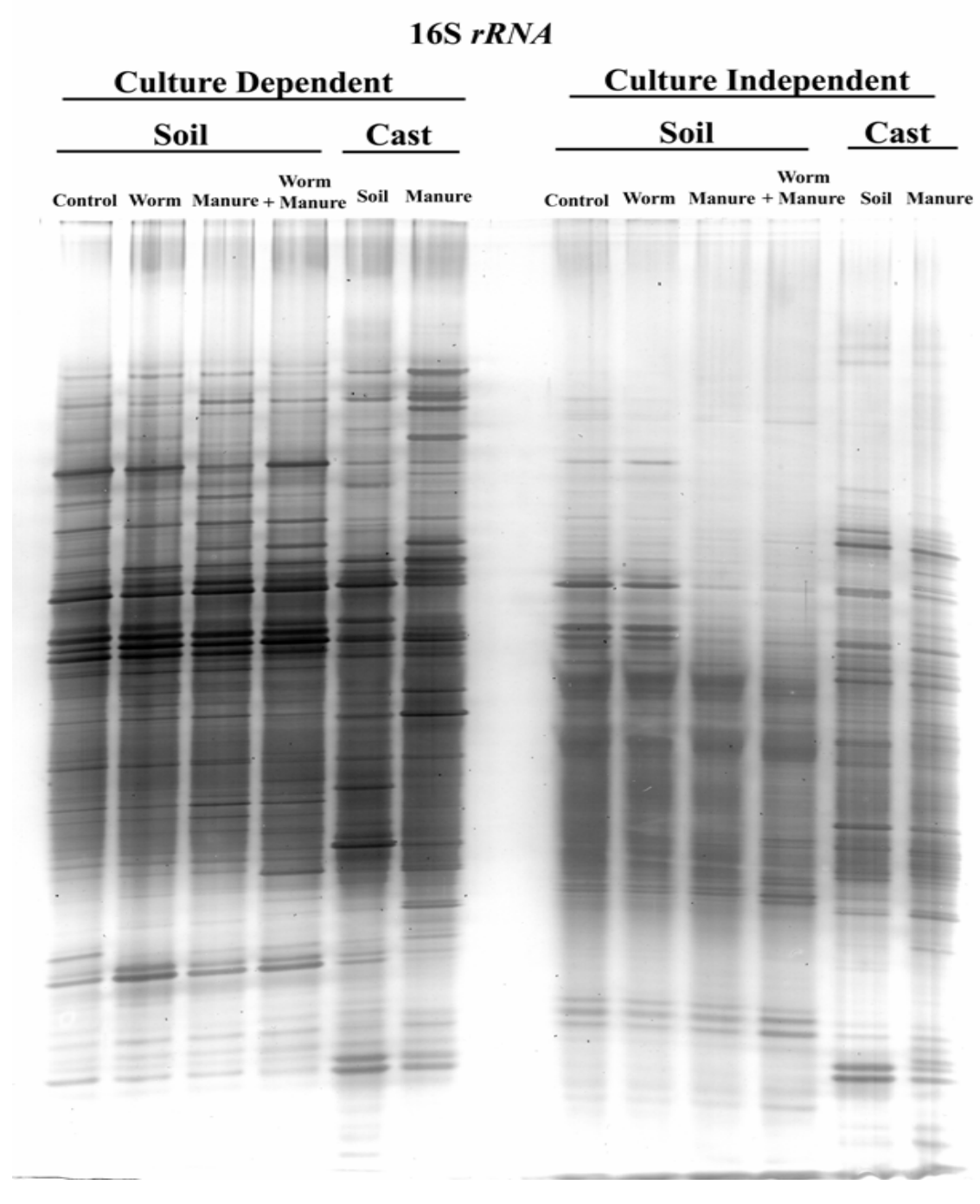

(b)

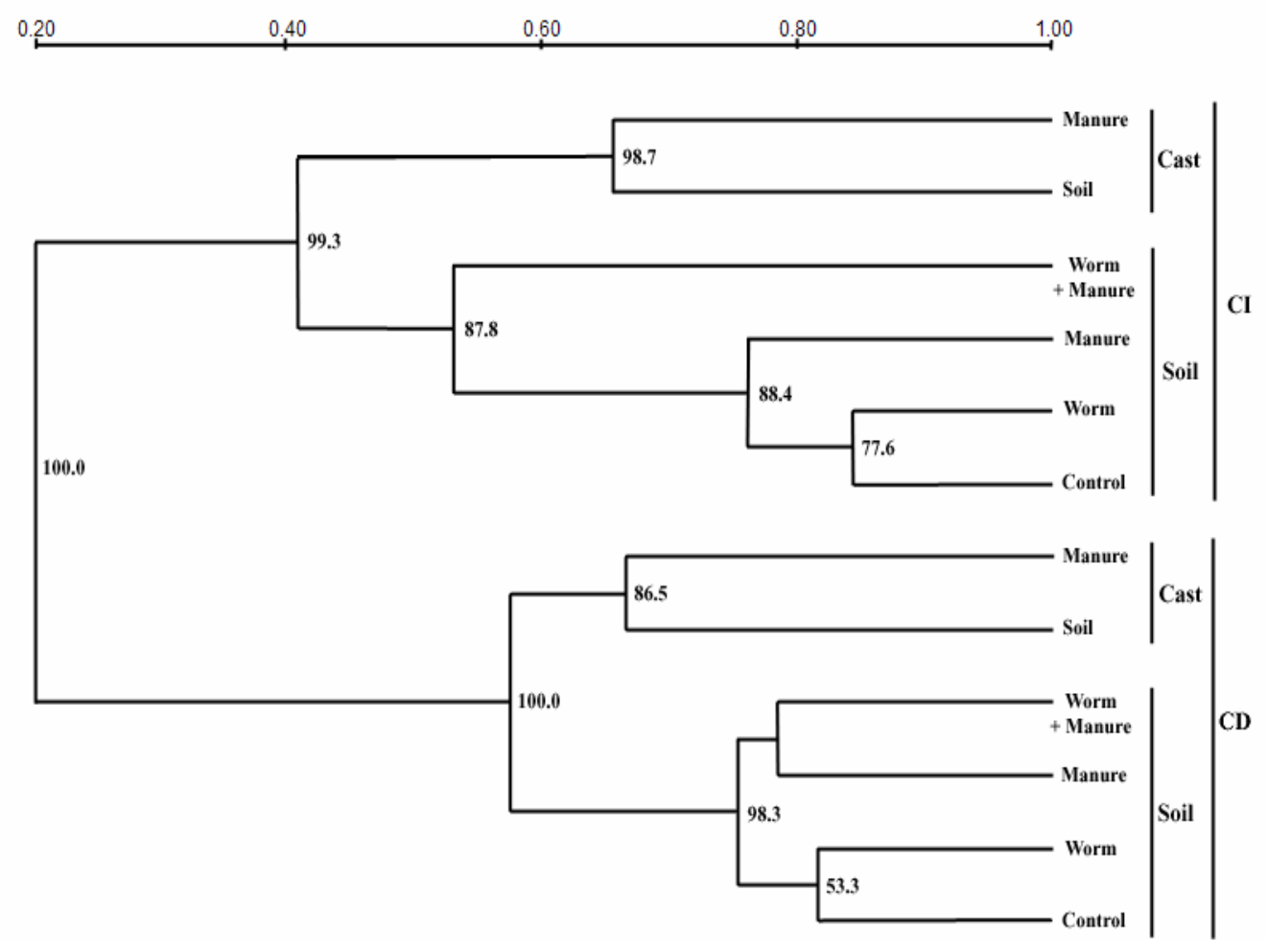

Figure 4. (a) DGGE gel of PCR-amplified 16S rRNA genes amplified from culture-dependent and culture-independent bacterial communities of pasture soil and $L$. terrestris casts. Each lane is a pooled sample composed of nine PCR reactions (b) UPGMA dendrogram constructed using the Dice similarity matrix generated from culture-dependent and-culture independent DGGE profiles of PCR-amplified 16S rRNA genes from pasture soil and casts from $L$. terrestris under different feeding conditions. The scale located above the tree indicates percent similarity. Numbers at nodes represent bootstrap values (1,000 resamplings). Bootstrap values below 40 were not reported. 


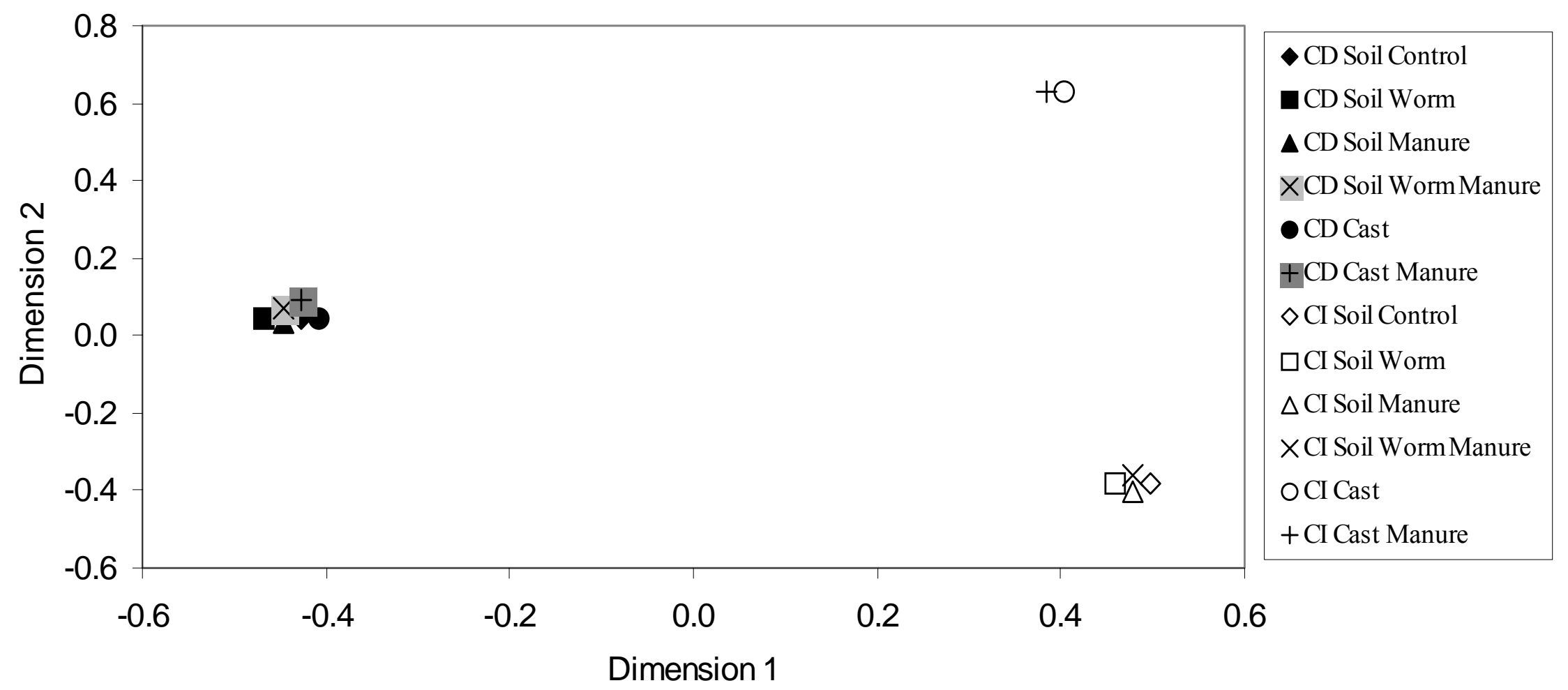

Figure 5. Multidimensional scaling (MDS) ordination plot based on mean Sorenson similarity values of combined culturedependent and culture-independent 16S rRNA DGGE profile of pasture soil and L. terrestris casts (Figure 4a.). Each material / treatment combination is a pooled sample composed of nine PCR reactions. ANOSIM $\mathrm{R}=0.95(\mathrm{P}<0.001)$ indicates a significant difference exists between treatment groups. CD (culture-dependent); CI (culture-independent). 
(a)

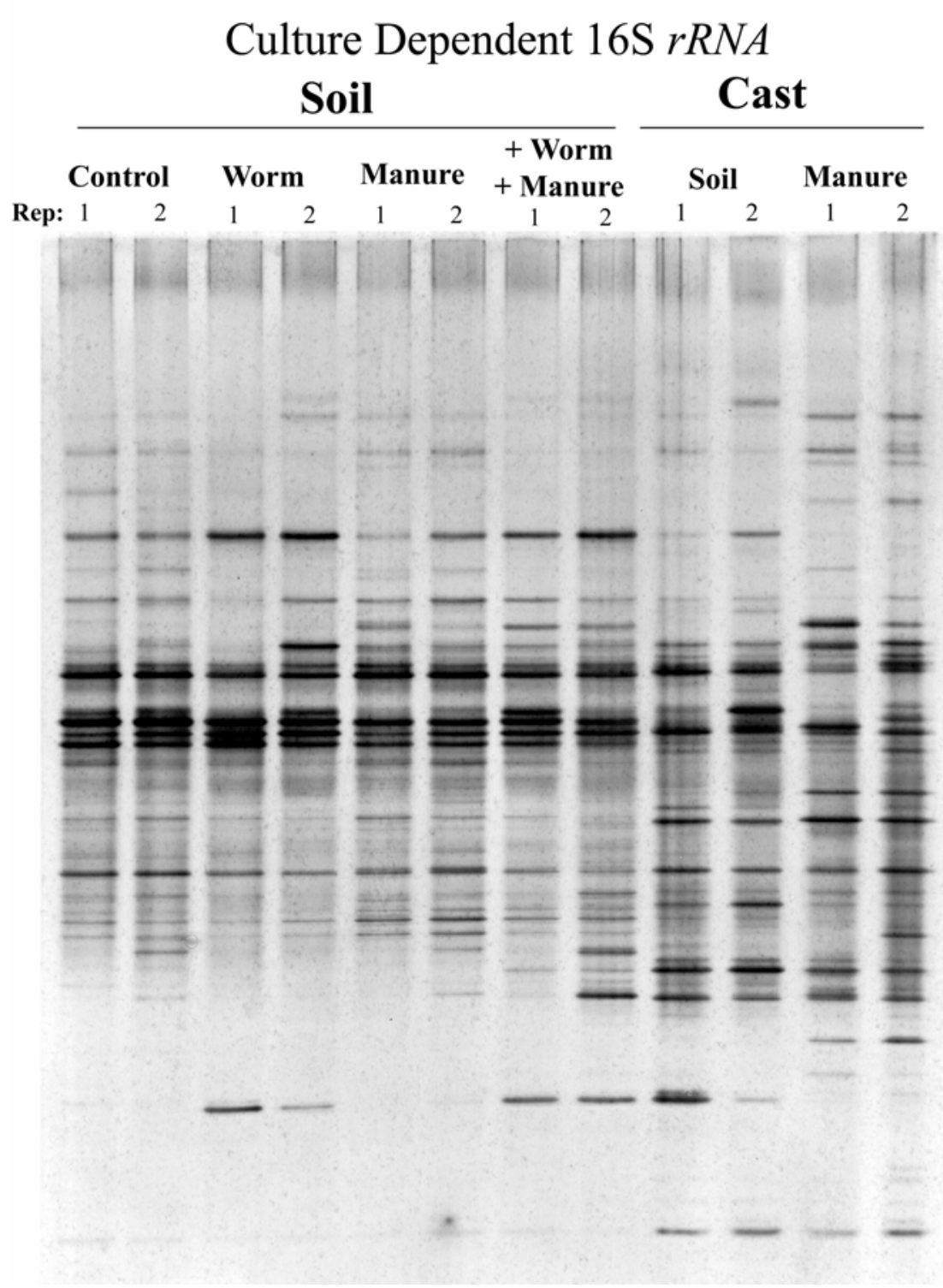

(b)

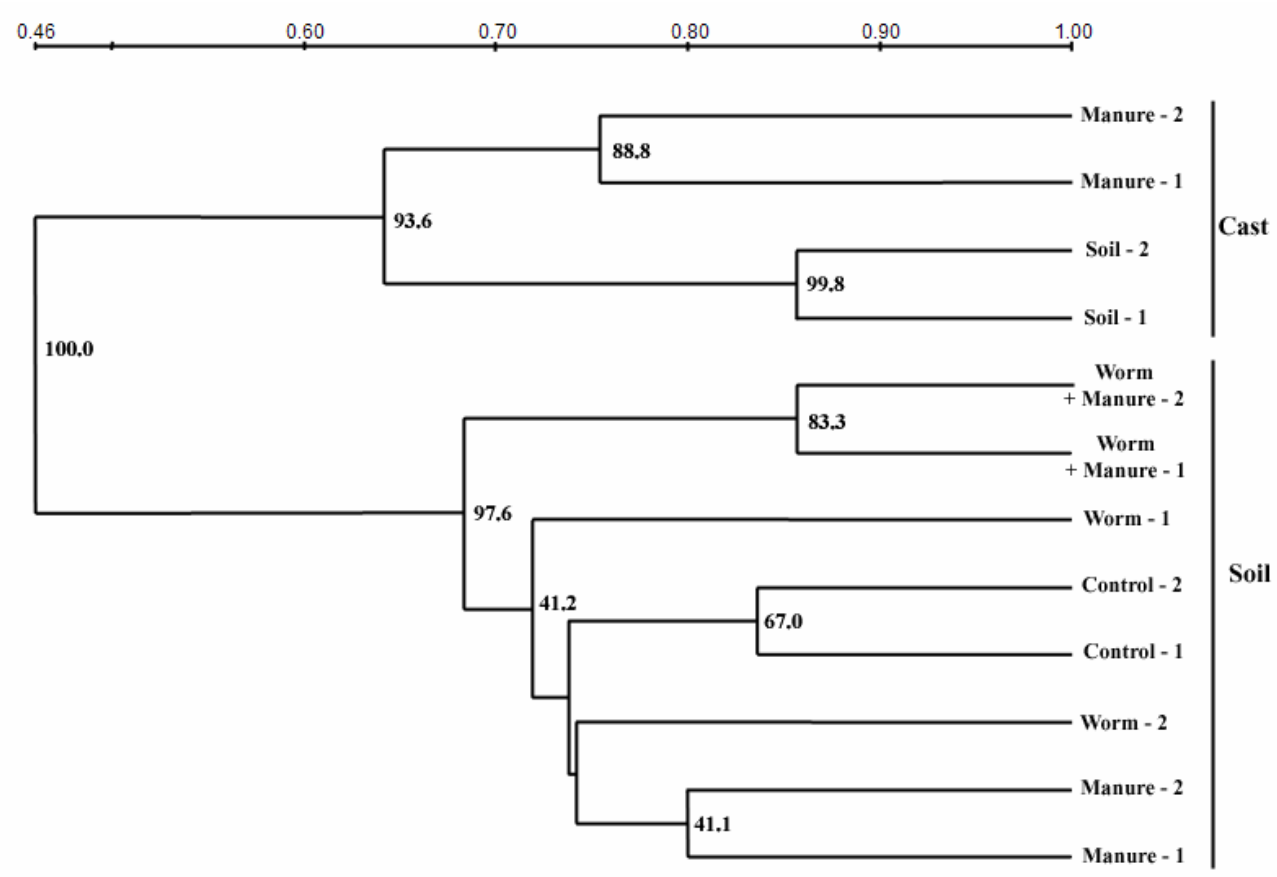

Figure 6. (a) DGGE gel of PCR-amplified 16S rRNA genes amplified from culture-dependent bacterial communities of pasture soil and $L$. terrestris casts. Each treatment has two replicate lanes each composed of three pooled PCR reactions (b) UPGMA dendrogram constructed using the Dice similarity matrix generated from culture-dependent DGGE profiles of PCR-amplified 16S rRNA genes from pasture soil and casts from $L$. terrestris under different feeding conditions. The scale located above the tree indicates percent similarity. Numbers at nodes represent bootstrap values (1,000 resamplings). Bootstrap values below 40 were not reported. 


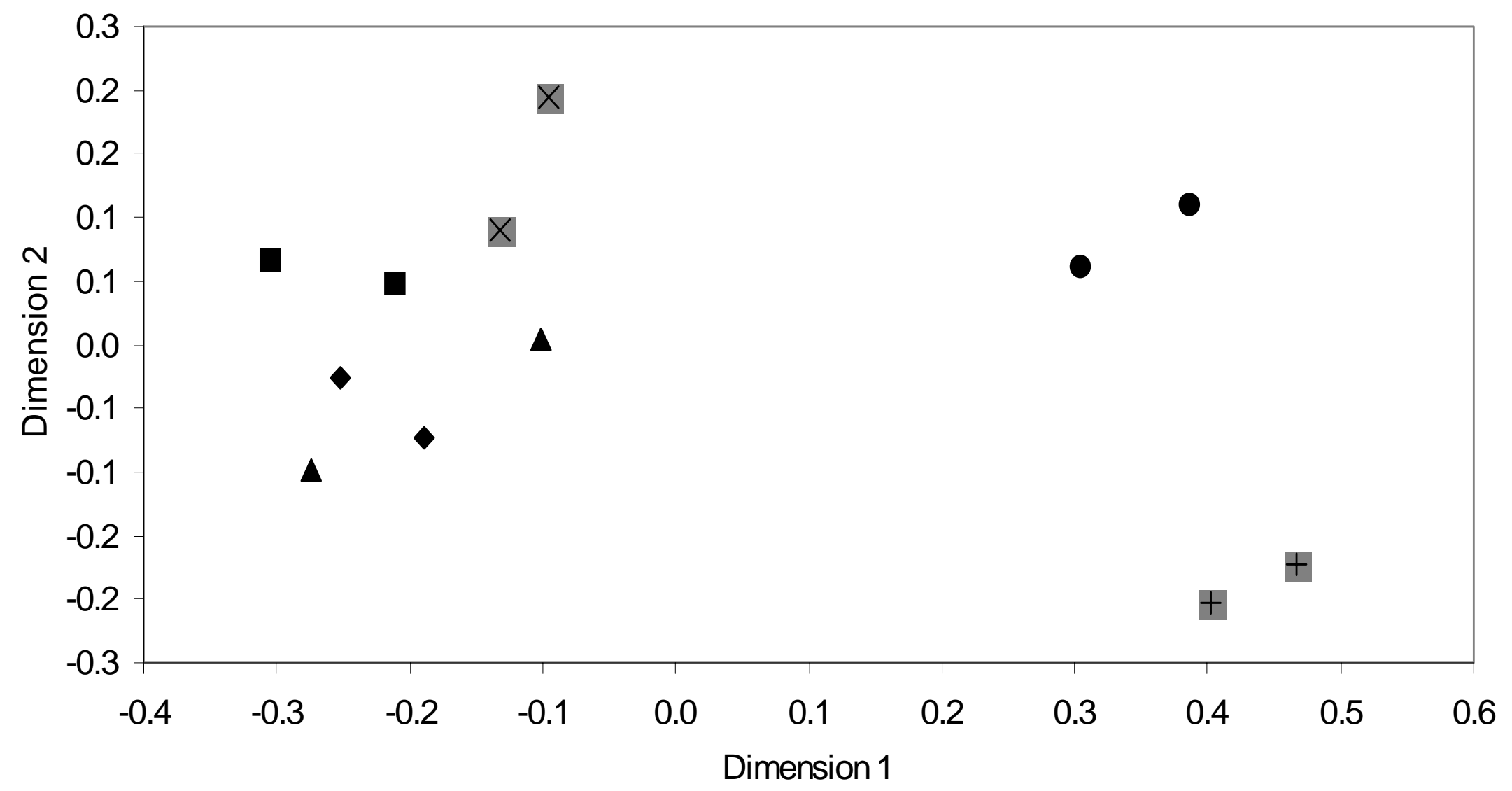

\section{$\bullet$ Soil Control $\square$ Soil Worm $\Delta$ Soil Manure XSoil Worm Manure • Cast +Cast Manure}

Figure 7. Multidimensional scaling (MDS) ordination plot based on mean Sorenson similarity values of culture-dependent $16 \mathrm{~S} r R N A$ DGGE profile of pasture soil and L. terrestris casts (Figure 6a). Each material / treatment combination has two replicate samples composed of three pooled PCR reactions. ANOSIM $\mathrm{R}=0.93(\mathrm{P}<0.001)$ indicates a significant difference exists between treatment groups. 
(a)

\section{Culture Independent 16S $r R N A$}

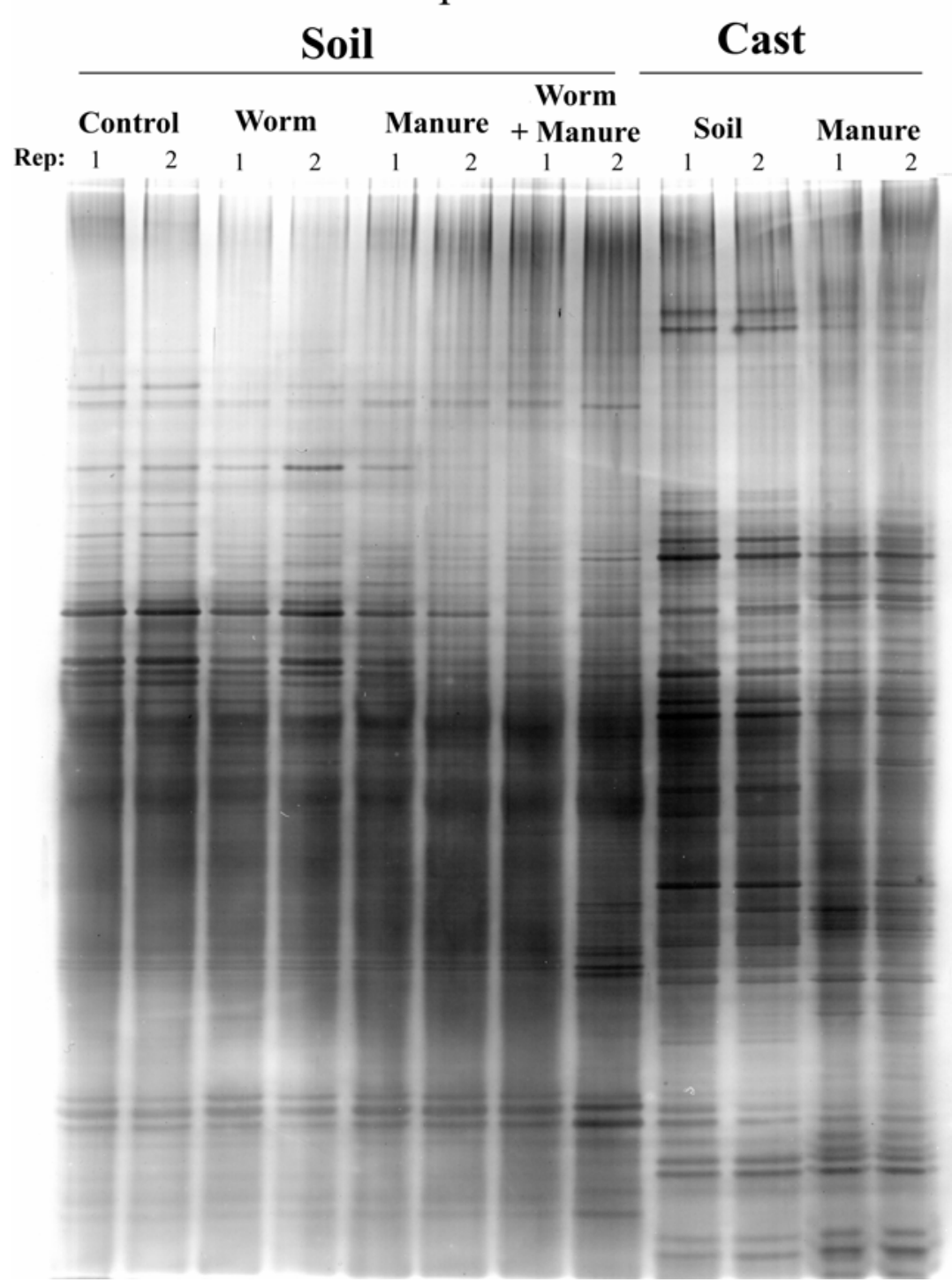

(b)

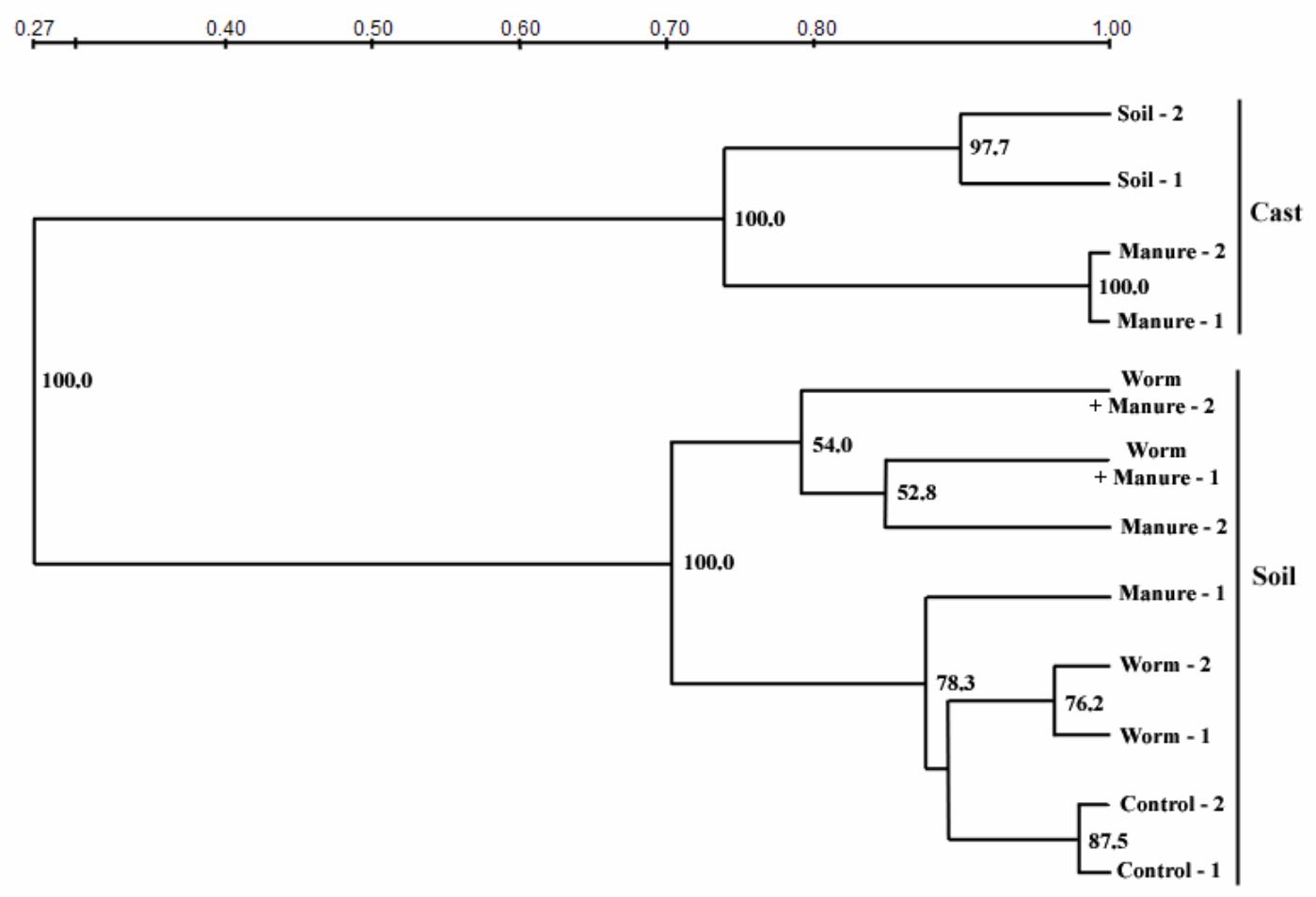

Figure 8. (a) DGGE gel of PCR-amplified 16S rRNA genes amplified from culture-independent bacterial communities of pasture soil and L. terrestris casts. Each treatment has two replicate lanes each composed of three pooled PCR reactions (b) UPGMA dendrogram constructed using the Dice similarity matrix generated from culture-independent DGGE profiles of PCR-amplified 16S rRNA genes from pasture soil and casts from $L$. terrestris under different feeding conditions. The scale located above the tree indicates percent similarity. Numbers at nodes represent bootstrap values (1,000 resamplings). Bootstrap values below 40 were not reported. 


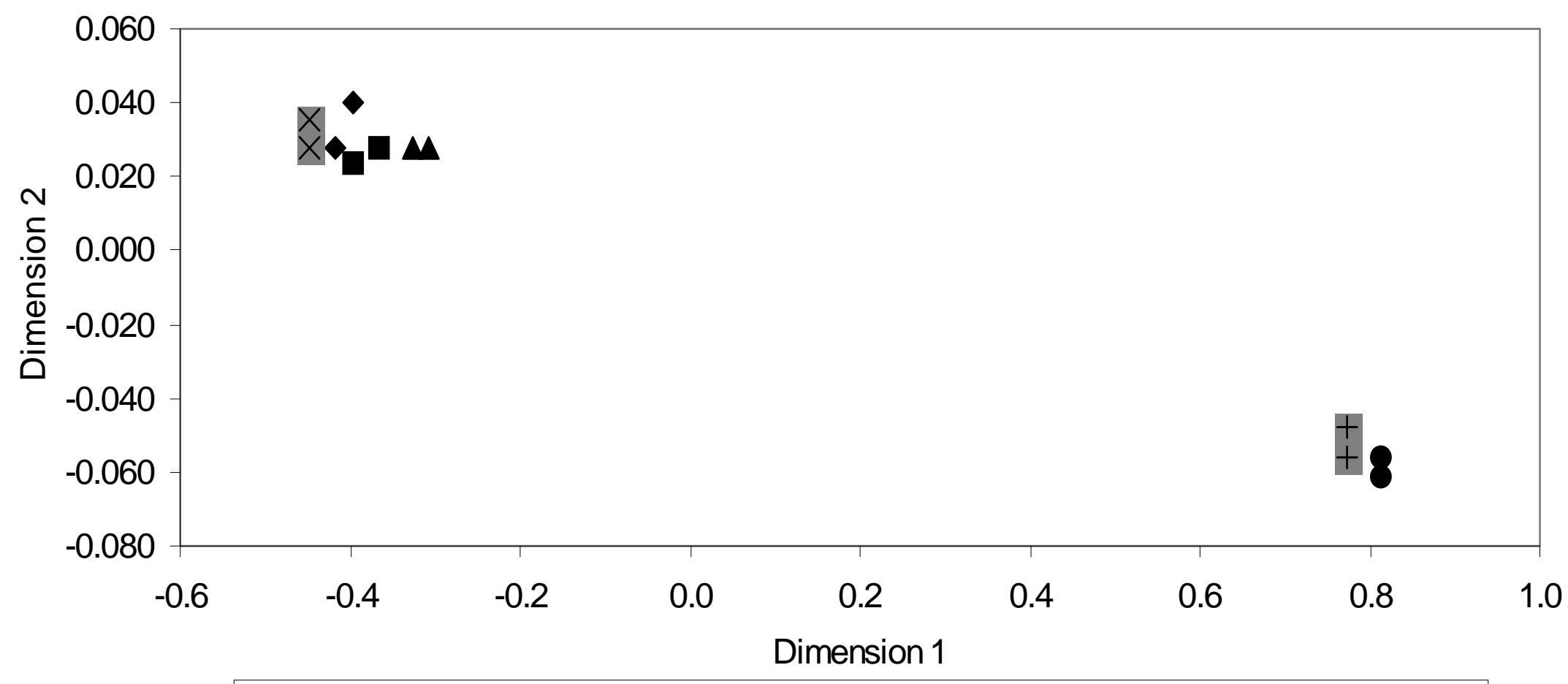

- Soil Control $\boldsymbol{\square}$ Soil Worm $\Delta$ Soil Manure $\times$ Soil Worm Manure • Cast + Cast Manure

Figure 9. Multidimensional scaling (MDS) ordination plot based on mean Sorenson similarity values of culture-independent 16S rRNA DGGE profile of pasture soil and L. terrestris casts (Figure 8a). Each material / treatment combination has two replicate samples composed of three pooled PCR reactions. ANOSIM R $=0.89(\mathrm{P}<0.001)$ indicates a significant difference exists between treatment groups. 
(a)

\section{nirK}

$\frac{\text { Culture Dependent }}{\text { Soil }} \frac{\text { Cast }}{\text { Worm }} \frac{\text { Manure }}{\text { Soil }}$

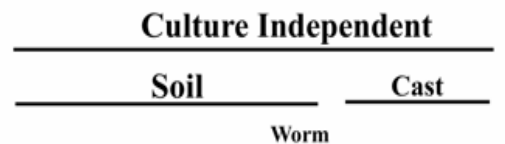

Control Worm Manure +Manure Soil Manure

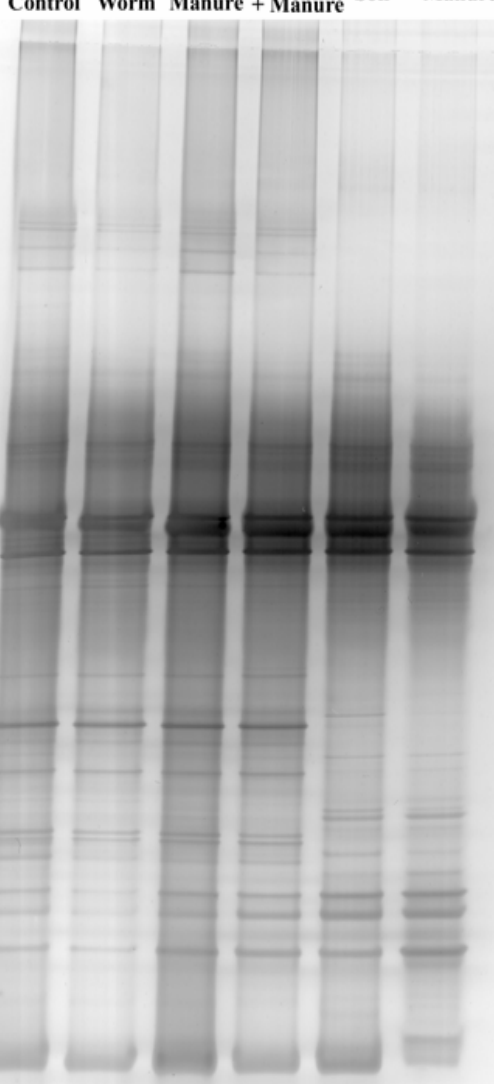

Control Worm Manure + Manure Soil Manure (b)

0.17 0.40 0.60 0.80 1.00

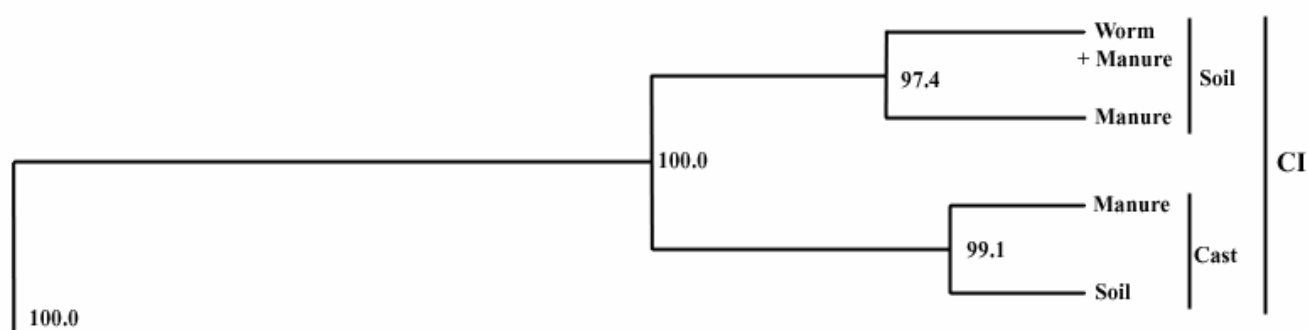

100.0
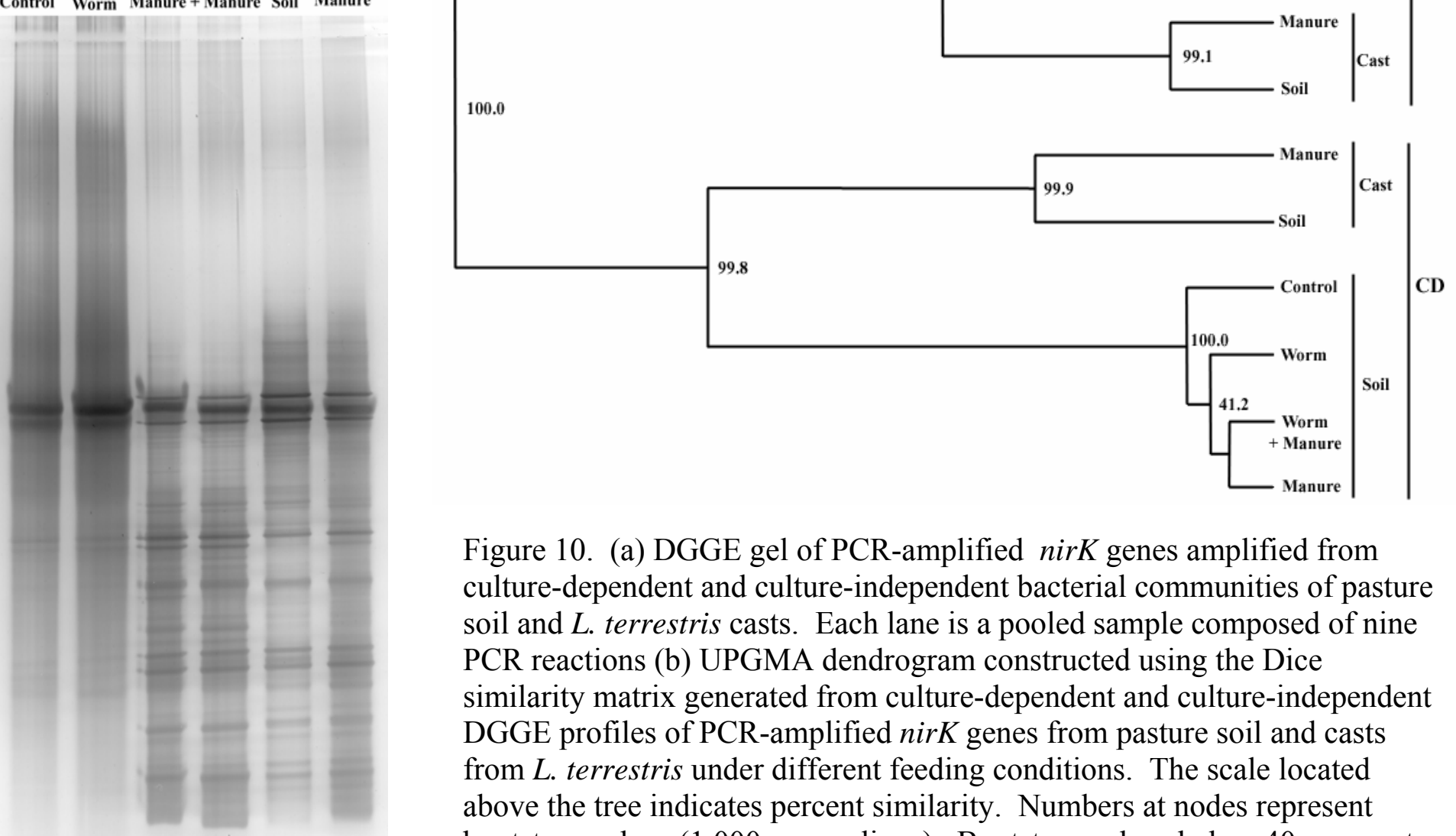

Figure 10. (a) DGGE gel of PCR-amplified nirK genes amplified from culture-dependent and culture-independent bacterial communities of pasture soil and L. terrestris casts. Each lane is a pooled sample composed of nine PCR reactions (b) UPGMA dendrogram constructed using the Dice similarity matrix generated from culture-dependent and culture-independent DGGE profiles of PCR-amplified nirK genes from pasture soil and casts from $L$. terrestris under different feeding conditions. The scale located above the tree indicates percent similarity. Numbers at nodes represent bootstrap values (1,000 resamplings). Bootstrap values below 40 were not reported. Soil control and soil with worm treatments were removed from analysis due to insufficient PCR amplification. 


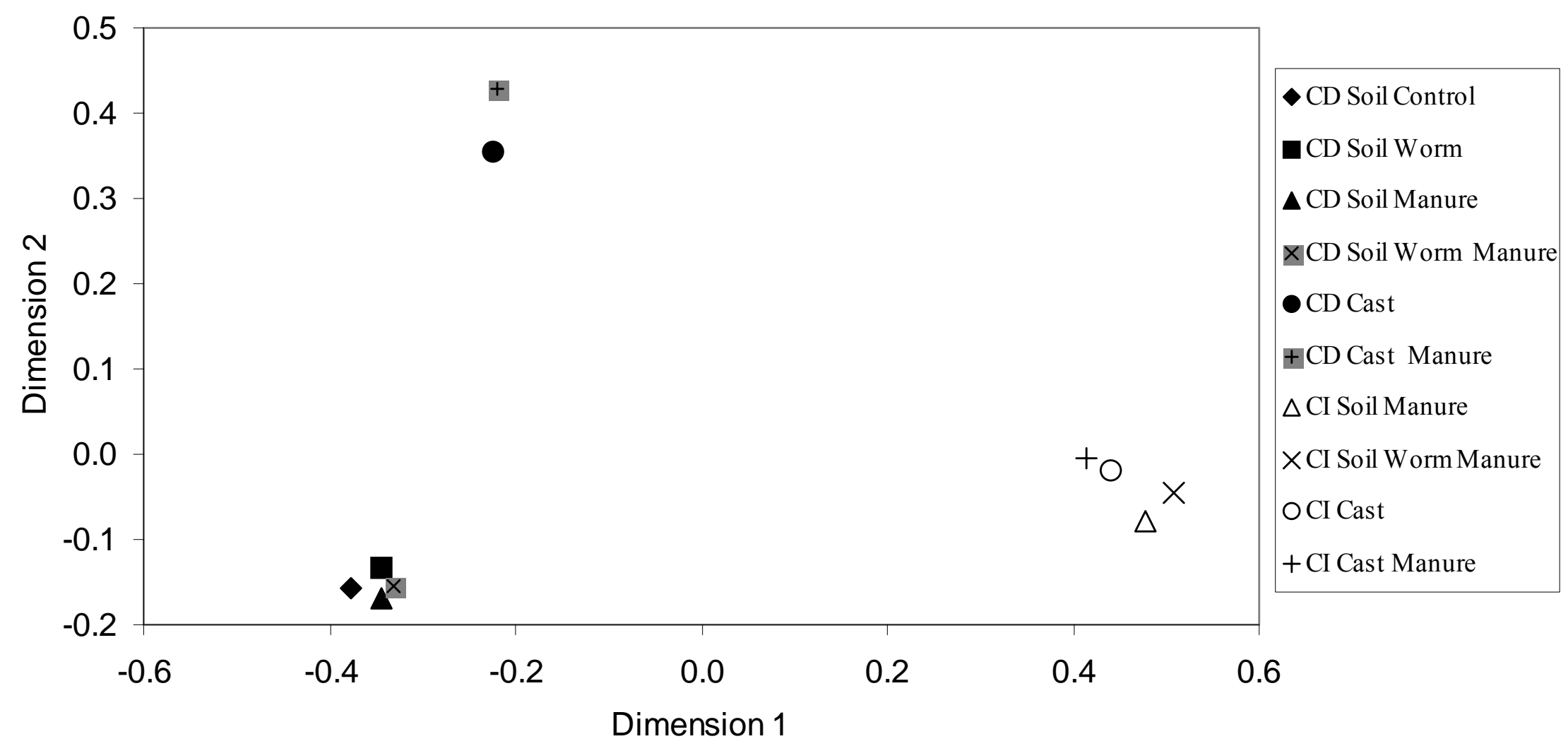

Figure 11. Multidimensional scaling (MDS) ordination plot based on mean Sorenson similarity values of combined culture-dependent and culture-independent nirK DGGE profile of pasture soil and L. terrestris casts (Figure 10a.). Each material / treatment combination is a pooled sample composed of nine PCR reactions. ANOSIM R $=1(\mathrm{P}<0.001)$ indicates a significant difference exists between treatment groups. Soil control and soil with worm treatments were removed from analysis due to insufficient PCR amplification. CD (culture-dependent); CI (culture-independent). 

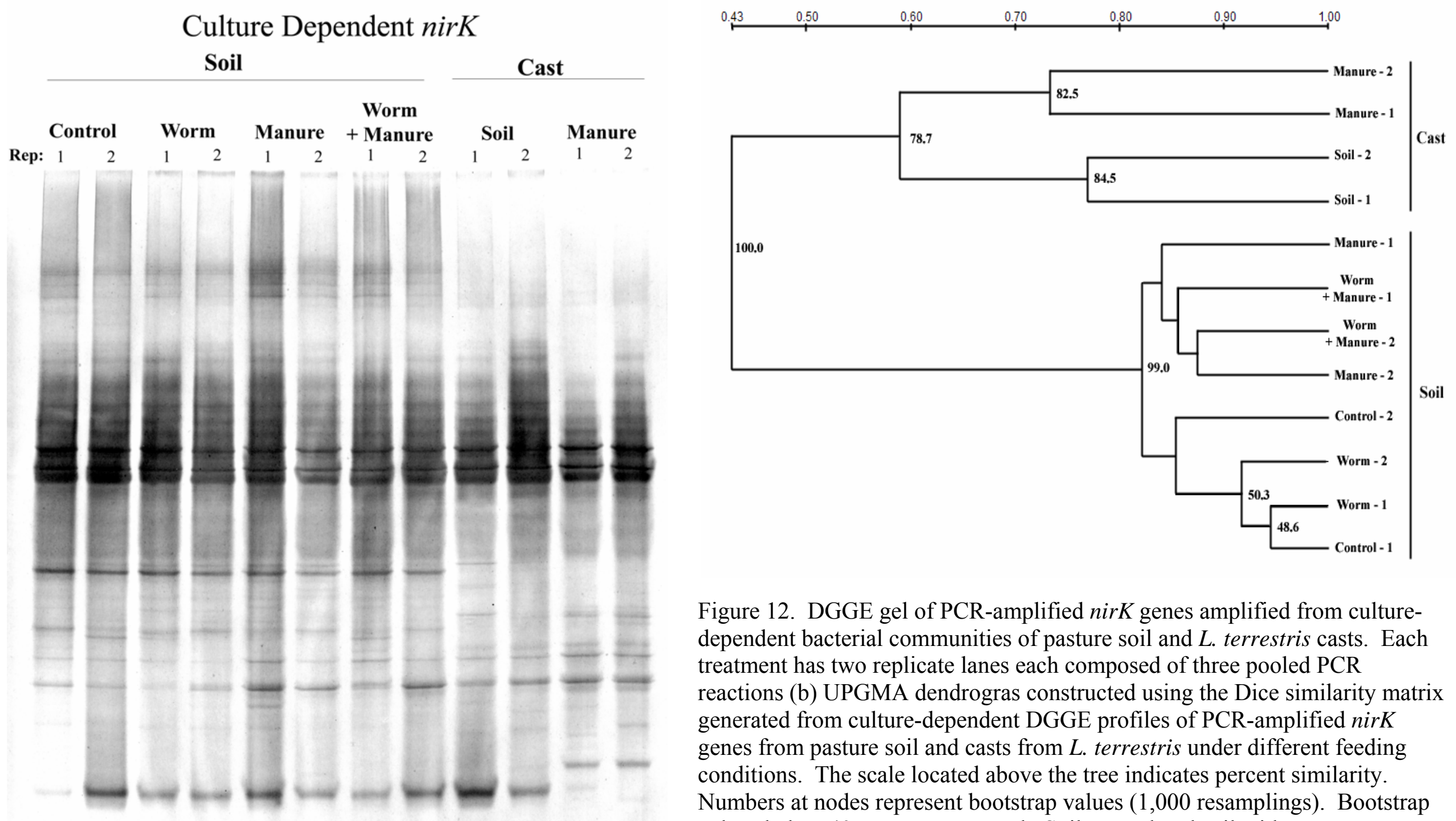

Figure 12. DGGE gel of PCR-amplified nirK genes amplified from culturedependent bacterial communities of pasture soil and L. terrestris casts. Each treatment has two replicate lanes each composed of three pooled PCR reactions (b) UPGMA dendrogras constructed using the Dice similarity matrix generated from culture-dependent DGGE profiles of PCR-amplified nirK genes from pasture soil and casts from $L$. terrestris under different feeding conditions. The scale located above the tree indicates percent similarity. Numbers at nodes represent bootstrap values (1,000 resamplings). Bootstrap values below 40 were not reported. Soil control and soil with worm treatments were removed from analysis due to insufficient PCR amplification. 


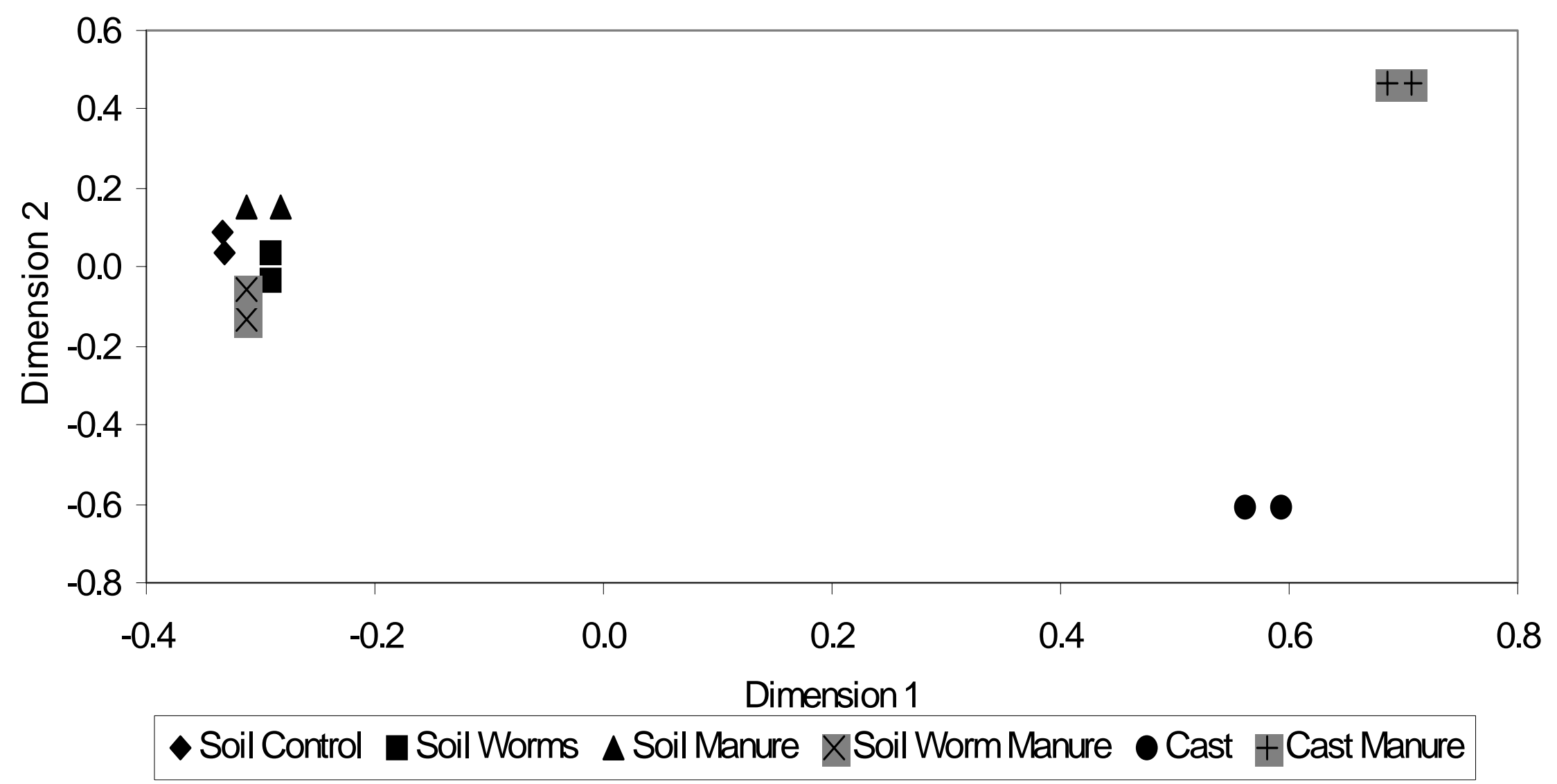

Figure 13. Multidimensional scaling (MDS) ordination plot based on mean Sorenson similarity values of culture-dependent nirK DGGE profile of pasture soil and $L$. terrestris casts (Figure 12a). Each material / treatment combination has two replicate samples composed of three pooled PCR reactions. ANOSIM R $=0.64(\mathrm{P}<0.001)$ indicates a significant difference exists between treatment groups. 
(a)

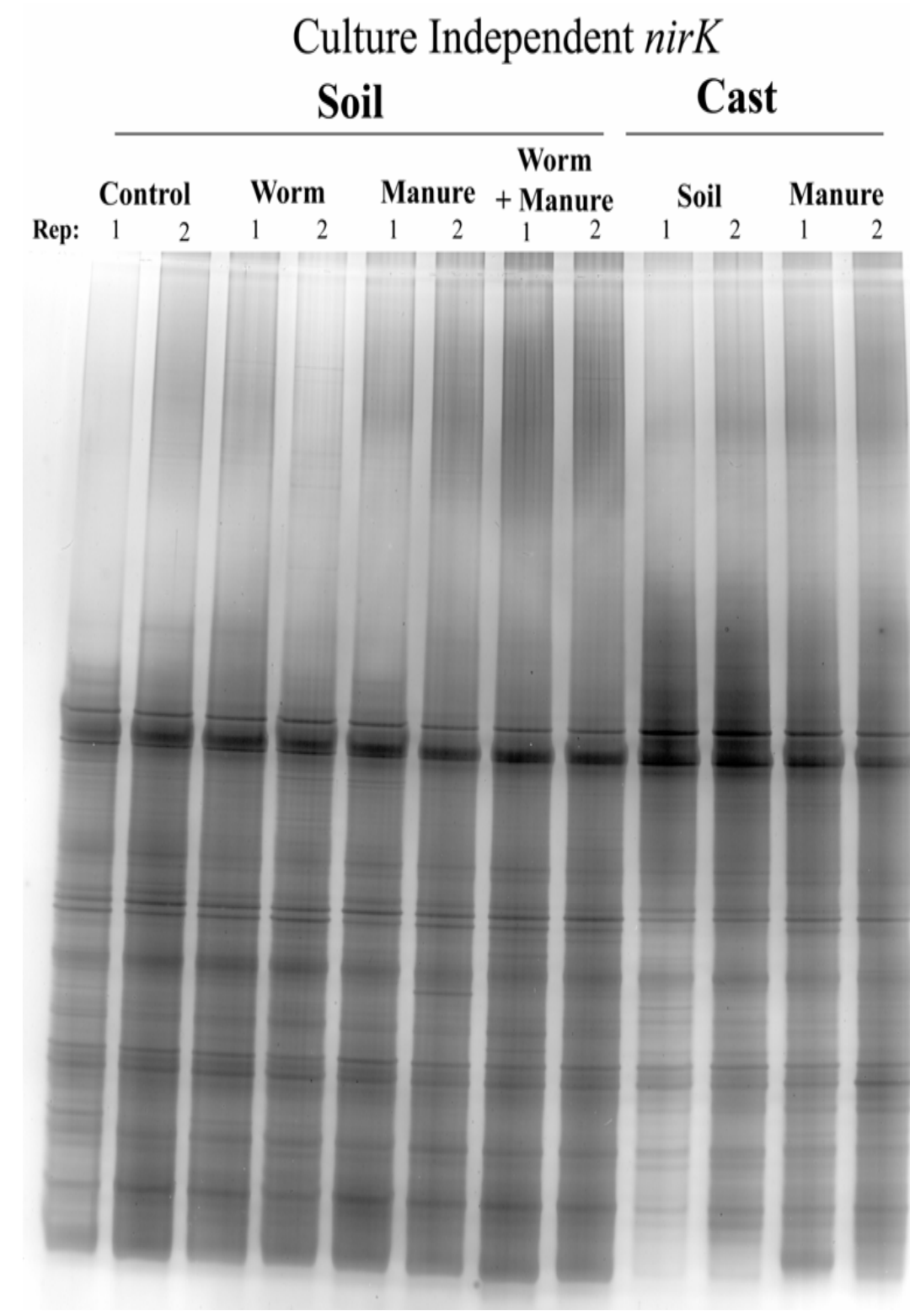

(b)

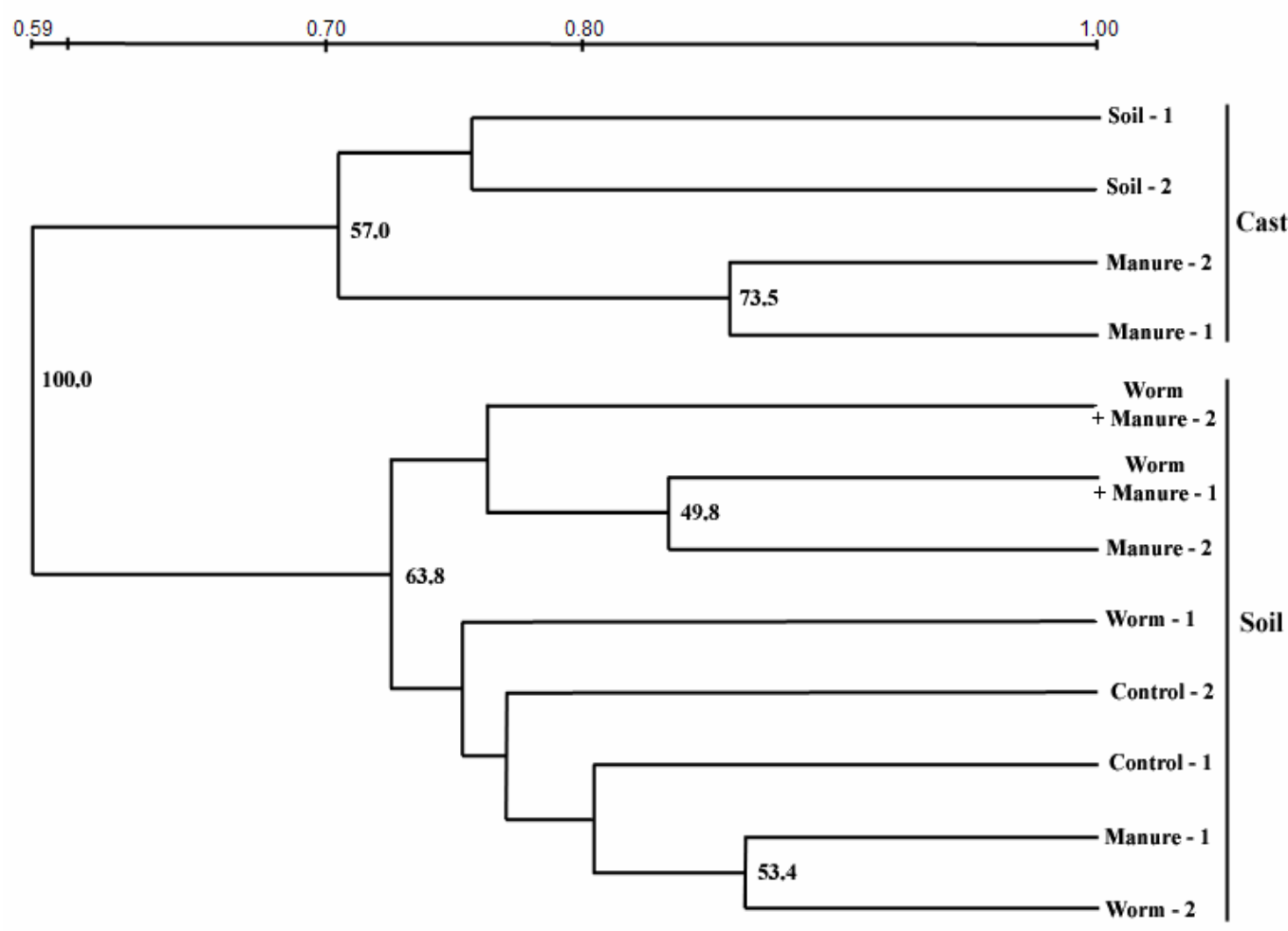

Figure 14. (a) DGGE gel of PCR-amplified nirK genes amplified from cultureindependent bacterial communities of pasture soil and L. terrestris casts. Each treatment has two replicate lanes each composed of three pooled PCR reactions (b) UPGMA dendrogram constructed using the Dice similarity matrix generated from culture-independent DGGE profiles of PCR-amplified nirK genes from pasture soil and casts from $L$. terrestris under different feeding conditions. The scale located above the tree indicates percent similarity. Numbers at nodes represent bootstrap values (1,000 resamplings). Bootstrap values below 40 were not reported. 


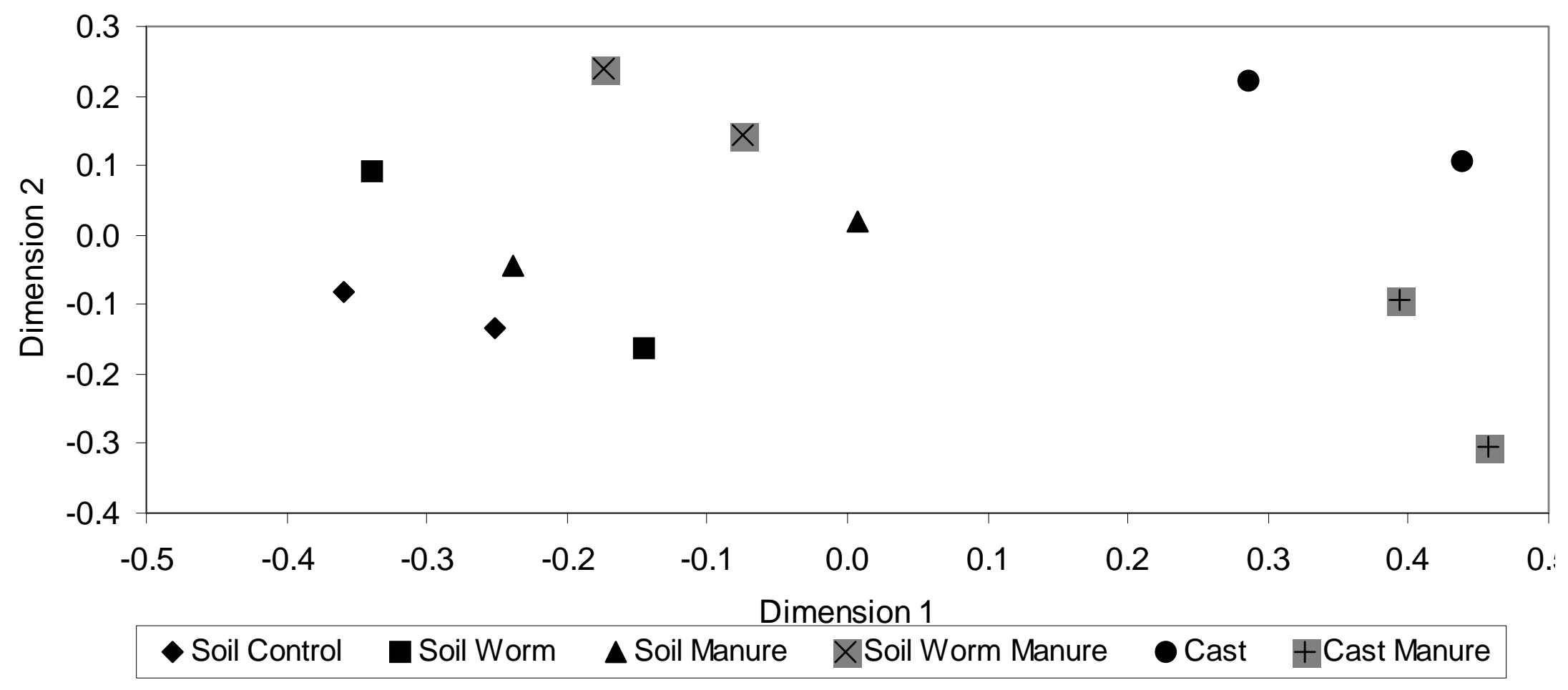

Figure 15. Multidimensional scaling (MDS) ordination plot based on mean Sorenson similarity values of culture-independent nirK DGGE profile of pasture soil and L. terrestris casts (Figure 14a). Each material / treatment combination has two replicate samples composed of three pooled PCR reactions. ANOSIM R $=0.70(\mathrm{P}<0.001)$ indicates a significant difference exists between treatment groups. 


\section{REFERENCE LIST}

Aira, M., F. Monroy and J. Dominguez. 2006. Changes in microbial biomass and microbial activity of pig slurry after the transit through the gut of the earthworm Eudrilus eugeniae (Kinberg, 1867). Biol. Fertil. Soils 42:371-376.

Barns, S. M., S. L. Takala and C. R. Kuske. 1999. Wide distribution and diversity of members of the bacterial kingdom Acidobacterium in the environment. Appl. Environ. Microbiol. 65:1731-1737.

Bending, G. D., C. Putland and F. Rayns. 2000. Changes in microbial community metabolism and labile organic matter fractions as early indicators of the impact of management on soil biological quality. Biol Fertil Soils 31:78-84.

Bending, G. D., M. K. Turner and J. E. Jones. 2002. Interactions between crop residues and soil organic matter quality and the functional diversity of soil microbial communities. Soil Biol. Biochem. 34:1073-1082.

Blakemore, R. J. 2002. Cosmopolitan earthworms: An eco-taxonomic guide to the peregrine species of the world (first CD edition). VermEcology, Australia

Bouche, M. B. 1983. The establishment of earthworm communities. In: Earthworm Ecology from Darwin to Vermiculture (J. E. Satchell, Ed.), pp. 431-448. Chapman and Hall, London, United Kingdom.

Brown, G. G. 1995. How do earthworms affect microflora and faunal community diversity? Plant and Soil 170:209-231.

Bruneau, P. M. C., D. A. Davidson, I. C. Grieve, I. M. Young and N. Nunan. 2005. The effects of soil horizons and faunal excrement on bacterial distribution in an upland grassland soil. FEMS Microbiol. Ecol. 52:39-144.

Bruns, M. A., J. R. Stephen, G. A. Kowalchuk, J. I. Prosser and E. A. Paul. 1999. Comparative diversity of ammonia oxidizer 16S rRNA gene sequences in native, tilled, and successional soils. Appl. Environ. Microbiol. 65:2994-3000.

Caetano-Anolles, G. C. and P. M. Gresshoff. 1994. Staining nucleic acids with silver: an alternative to radioisotopic and fluorescent labeling. Promega Notes Mag. 45:13-19.

Campbell, C. D., S. J. Grayston and D. J. Hirst. 1997. Use of rhizosphere carbon sources in sole carbon source tests to discriminate soil microbial communities. Journal of Microbial Methods 30:30-41. 
Chevallier, J. T., M. Lieffering, R. A. Carran and P. C. D. Newton. 2006. Mineral nitrogen cycing through earthworm casts in grazed pasture under elevated atmospheric $\mathrm{CO}_{2}$. Global Change Biology 12:56

Crecchio, C., A. Gelsomino, R. Ambrosoli, J. L. Minati and P. Ruggiero. 2004. Functional and molecular responses of soil microbial communities under differing soil management practices. Soil Biol. Biochem. 36:1873-1883.

Coyne, M. S., A. Arunakumari, B. A. Averill and J. M. Tiedje. 1989. Immunological identification and distribution of dissimilatory heme $c d_{1}$ and nonheme copper nitrite reductases in denitrifying bacteria. Appl. Environ. Microbiol. 55:29242931.

Daniel, O. and J. M. Anderson. 1992. Microbial biomass and activity in contrasting soil materials after passage through the gut of the earthworm Lumbricus rubellus Hoffmeister. Soil Biol. Biochem 24:465-470.

Devliegher, W. and W. Verstraete. 1997. Microorganisms and soil physiochemical conditions in the drilosphere of Lumbricus terrestris. Soil Biol. Biochem. 29:1721-1729.

Dindal, D. L. 1990. Soil Biology Guide. John Wiley and Sons, New York.

Duineveld, B. M., A. S. Rosado, J. D. van Elsas and J.A. van Veen. 1998. Analysis of the dynamics of bacterial communities in the rhizosphere of the chrysanthemum via denaturing gradient gel electrophoresis and substrate utilization patterns. Appl. Environ. Microbiol. 64:4950-4957.

Dunbar, J., S. Takala, S. M. Barns, J. A. Davis and C. R. Kuske. 1999. Levels of bacterial community diversity in four arid soils compared by cultivation and $16 \mathrm{~S}$ rRNA gene cloning. Appl. Environ. Microbiol. 65:1662-1669.

Edwards, C. A. and K. E. Fletcher. 1988. Interactions between earthworms and microorganisms in organic-matter breakdown. Agric. Ecosys. Environ. 24:235247.

Edwards, C. A., and P. J. Bohlen. 1996. Biology of earthworms. Chapman and Hall, London, United Kingdom.

Egert, M., S. Marhan, B. Wagner, S. Scheu and M. W. Friedrich. 2004. Molecular profiling of $16 \mathrm{~S}$ rRNA genes reveals diet-related differences of microbial communities in soil, gut and cast of Lumbricus terrestris L. (Oligochaeta: Lumbricidae). FEMS Microbiol. Ecol. 48:187-197.

Egert, M., B. Wagner, T. Lemke, A. Brune, and M.W. Friedrich. 2003. Microbial Community Structure in Midgut and Hindgut of the Humus-Feeding Larva of Pachnoda ephippiata (Coleoptera: Scarabaeidae). Appl. Environ. Microbiol. 
69:6659-6668.

Elliott, P. W. and J. M. Anderson. 1990. Denitrification in earthworm casts and soil from pastures under different fertilizer and drainage regimes. Soil Biol. Biochem. 22:601-605.

Ellis, R. J., P. Morgan, A. J. Weightman and J. C. Fry. 2003. Cultivation-dependent and -independent approaches for determining bacterial diversity in heavy-metalcontaminated soil. Appl. Environ. Microbiol. 69:3223-3230.

Fischer, K., D. Hahn, R. I. Amann, O. Daniel and J. Zeyer. 1995. In situ analysis of the bacterial community in the gut of the earthworm Lumbricus terrestris L. by whole-cell hybridization. Can. J. Mircrobiol. 41:666-673.

Fischer, K., D. Hahn, W. Honerlage and J. Zeyer. 1997. Effect of passage through the gut of the earthworm Lumbricus terrestris L. on Bacillus megaterium studied by whole cell hybridization. Soil Biol. Biochem. 29:149-1152

Frostegard, A., S. O. Petersen, E. Baath, and T. H. Nielsen. 1997. Dynamics of a microbial community associated with manure hot spots as revealed by phospholipid fatty acid analysis. Appl. and Environ.. Microbiol. 63:2224-2231.

Furlong, M. A., D. R. Singleton, D. C. Coleman and W. B. Whitman. 2002. Molecular and culture-based analyses of prokaryotic communities from an agricultural soil and the burrows and casts of the earthworm Lumbricus rubellus. Appl. Environ. Microbiol 68:1265-1279.

Gamble, T. N., M. R. Betlach, and J. M. Tiedje. 1977. Numerically dominant denitrifying bacteria from world soils. Appl. Environ. Microbiol. 33:926-939.

Garland, J. L. and A. L. Mills. 1991. Classification and characterization of heterotrophic microbial communities on the basis of patterns of community-level sole carbon source utilization. Appl. Environ. Microbiol. 57:2351-2359.

Garland, J. L. 1997. Analysis and interpretation of community-level physiological profiles in microbial ecology. FEMS Microbiol. Ecol. 24:289-300.

Ge, F., W. D. Shuster, C. A. Edwards, R. W. Parmelee and S. Subler. 2001. Water stability of earthworm casts in manure-and inorganic-fertilizer amended agroecosystems influenced by age and depth. Pedobiologia 45:12-26.

Girvan, M. S., J. Bullimore, J. N. Pretty, A. M. Osborn and A. S. Ball. 2003. Soil type is the primary determinant of the composition of the total and active bacterial communities in arable soils. Appl. Environ. Microbiol. 69:1800-1809.

Grayston, S. J., C. D. Campbell, R. D. Bardgett, J. L. Mawdsley, C. D. Clegg, K. Ritz, B. S. Griffiths, J. S. Rodwell, S. J. Edwards, W. J. Davies, D. J. Elston 
and P. Millard. 2004. Assessing shifts in microbial community structure across a range of grasslands of differing management intensity using CLPP, PLFA and community DNA techniques. Appl. Soil Ecol. 25:63-84.

Hallin, S. and P.E. Lindgren. 1999. PCR detection of genes encoding nitrite reductase in denitrifing bacteria. Appl. Environ. Microbiol. 65:1652-1657.

Horn, M. A., A. Schramm and H. Drake. 2003. The earthworm gut: an ideal habitat for ingested $\mathrm{N}_{2} \mathrm{O}$-producing microorganisms. Appl. Environ. Microbiol. 69:16621669.

Horn, M.A., R. Mertel, M. Gehre, M. Kastner and H.L. Drake. 2006. In vivo emission of dinitrogen by earthworms via denitrifying bacteria the gut. Appl. Environ. Microbiol. 72: 1013-1018.

Hugenholtz, P., B. M. Goebel and N. R. Pace. 1998. Impact of culture-independent studies on the emerging phylogenetic view of bacterial diversity. J. Bacteriol. 180:4765-4774.

Ihssen, J., M. A. Horn, C. Matthies, A. GoBner, A. Schramm and H. L. Drake. 2003. $\mathrm{N}_{2} \mathrm{O}$-Producing microorganisms in the gut of the earthworm Aporrectodea caliginosa are indicative of ingested soil bacteria. Appl. Environ. Microbiol 69:1655-1661.

Jolly, J. M., H. M. Lappin-Scott, J. M. Anderson and C. D. Clegg. 1993. Scanning electron microsopy of the gut microflora of two earthworms: Lumbricus terrestris and Octolasion cyaneum. Microb. Ecol. 26:235-245.

Karsten, G. R. and H. L. Drake. 1997. Denitrifying bacteria in the earthworm gastrointestinal tract and in vivo emission of nitrous oxide $\left(\mathrm{N}_{2} \mathrm{O}\right)$ by earthworms. Appl. Environ. Microbiol. 63:1878-1882.

Konopka, A., L. Oliver and R. F. Turco Jr.. 1998. The use of carbon substrate utilization patterns in environmental and ecological microbiology. Microb. Ecol. 35:103-115.

Kristufek, V., K. Ravasz and V. Pizl. 1992. Changes in densities of bacteria and microfungi during gut transit in Lumbricus rubellus and Aporrectodea caliginosa (Oligochaeta: Lumbricidae). Soil Biol. Biochem. 24:1499-1500.

Langenheder, S., E. S. Lindstrom and L. J. Tranvik. 2006. Structure and functions of bacterial communities emerging from different sources under identical conditions. Appl. Environ. Microbiol. 72:212-220.

Malosso, E., L. English, D.W. Hopkins, and A.G. O’Donnell. 2005. Community level physiological profile response to plant residue additions in Antarctic soils. Biol. Fertil. Soils. 42: 60-65. 
Matthies, C., A. Griebhammer, M. Schmittroth and H. L. Drake. 1999. Evidence for involvement of gut-associated denitrifying bacteria in emission of nitrous oxide $\left(\mathrm{N}_{2} \mathrm{O}\right)$ by earthworms obtained from garden and forest soils. Appl. Environ. Microbiol. 65:3599-3604.

Miethling, R., G. Wieland, H. Backhaus and C. C. Tebbe 2000. Variation of microbial rhizosphere communities in response to crop species, soil origin, and inoculation with Sinorhizobium meliloti L33. Microb. Ecol. 41:43-56.

McCaig, A. E., L. A. Glover, and J. I. Prosser. 2001. Numerical analysis of grassland bacterial community structure under different land management regimens by using $16 \mathrm{~S}$ ribosomal DNA sequence data and denaturing gradient gel electrophoresis banding patterns. Appl. Environ. Microbiol. 67:4554-4559.

Muyzer, G., E. C. de Waal and A. G. Uitterlinden. 1993. Profiling of complex microbial populations by denaturing gradient gel electrophoresis analysis of polymerase chain reaction-amplified genes coding for 16S rRNA. Appl. Environ. Microbiol. 59:695-700.

Nakatsu, C. H., V. Torsvik and L. Ovreas. 2000. Soil community analysis using DGGE of $16 \mathrm{~S}$ rDNA polymerase chain reaction products. Soil Sci. Soc. Am. J. 64:1382-1388.

Nicol, G. W., L. A. Glover, and J. I. Prosser. 2003. Spatial analysis of archaeal community structure in grassland soil. Appl. Environ. Microbiol. 69:7420-7429.

Oliver, J. D. 1993. Formation of viable but nonculturable cells. In: Starvation in bacteria (Kjelleberg, S., Ed.), pp. 239-272. Plenum Press, New York, N.Y.

Ovreas, L. and V. V. Torsvik. 1998. Microbial diversity and community structure in two different agricultural soil communities. Microb. Ecol. 36:303-315.

Parle, J. N. 1963. Micro-organisms in the intestines of earthworms. J. Gen. Microbiol. 31:1-11.

Pedersen, J. C. and N. B. Hendriksen. 1993. Effect of passage through the intestinal tract of detritivore earthworms (Lumbricus spp.) on the number of selected Gramnegative and total bacteria. Biol. Fertil. Soils 16:227-232

Patton, B. J. 1959. Soil survey, Preston County, West Virginia (Fieldwork by D. C. Taylor, and others. Reported by B. J. Patton, W. W. Beverage and G. G. Pohlman. Correlation by A. J. Baur.). Washington, U.S. Govt. Print. Off. 
Perez-Piqueres, A., V. Edel-Hermann, C. Alabouvette and C. Steinberg. 2006. Response of soil microbial communities to compost amendments. Soil Biol. Biochem. 38:460-470.

Preston-Mafham, J., L. Boddy and P. F. Randerson. 2002. Analysis of microbial community functional diversity using sole-carbon-source utilization profiles - a critique. FEMS Microbiol. Ecol. 42:1-14.

Rees, G.N., D. S. Baldwin, G. O. Watson, S. Perryman and D. L. Nielsen. 2004. Ordination and significance testing of microbial community composition derived from terminal restriction fragment length polymorphisms: application and multivariate statistics. Antonie Leeuwenhoek. 86:339-347.

Salles, J. F., J. A. van Veen and J. D. van Elsas. 2004. Multivariate analyses of Burkholderia species in soil: Effect of crop and land use history. Appl. Environ. Microbiol. 70:4012-4020.

Schmitt-Wagner, D., M. W. Friedrich, B. Wagner and A. Brune. 2003. Phylogenetic Diversity, Abundance, and Axial Distribution of Bacteria in the Intestinal Tract of Two Soil-Feeding Termites (Cubitermes spp.). Appl. Envir. Microbiol. 69:60076017.

Schonholzer, F., D. Hahn and J. Zeyer. 1999. Origins and fate of fungi and bacteria in the gut of Lumbricus terrestris L. studied by image analysis. FEMS Microbiol. Ecol. 28:235-248.

Sharma, S., A. Rangger and H. Insam. 2003. Effects of decomposing maize litter on community level physiological profiles of soil bacteria. Microb. Ecol. 35:301310 .

Singh, B. K., S. Munro, E. Reid, B. Ord, J. M. Potts, E. Paterson and P. Millard. 2006. Investigating microbial community structure in soils by physiological, biochemical and molecular fingerprinting methods. Europ. J. Soil Sci. 57:72-82.

Singleton, D. R., M. A. Furlong, S. L. Rathbun and W. B. Whitman. 2001. Quantitative comparisons of 16S rRNA gene sequence libraries from environmental samples. Appl. Environ. Microbiol. 67:4374-4376.

Smalla, K., G. Wieland, A. Buchner, A. Zock, J. Parzy, S. Kaiser, N. Roskot, H. Heuer and G. Berg. 2001. Bulk and rhizosphere soil bacterial communities studied by denaturing gradient gel electrophoresis: Plant-dependent enrichment and seasonal shifts revealed. Appl. Environ. Microbiol. 67:4742-4751. 
Thorpe, I. S., J. I. Prosser, L. A. Glover and K. Killham. 1996. The role of the earthworm Lumbricus terrestris in the transport of bacterial inocula through soil. Biol. Fertil. Soils 23:132-139.

Throback, I. N., K. Enwall, A. Jarvis and S. Hallin. 2004. Reassessing PCR primers targeting nirS, nirK and nosZ genes for community surveys of denitrifying bacteria with DGGE. FEMS Microb. Ecol. 49:401-417.

Tomlin, A. D., M. J. Shipitalo, W. M. Edwards and R. Protz. 1995. Earthworms and their influence on soil structure and infiltration. In: Earthworm ecology and biogeography (Hendrix, P. F., Ed.), pp. 159-183. Lewis Publishers, Boca Raton.

Toyota, K., and M. Kimura. 2000. Microbial community indigenous to the earthworm Eisenia foetida. Biol. Fertil. Soils 31:187-190.

Van Hannen, E. 2005. DGGEstat. http://ddgehelp.blogspot.com. [Online]

Whalen, J. K., L. Sampedro and T. Waheed. 2004. Quantifying surface and subsurface cast prodution by earthworms under controlled laboratory conditions. Biol Fertil. Soils 39:287-291.

Widmer, F., A. Flieûbach, E. Laczko, J. Schulze-Aurich and J. Zeyer. 2001. Assessing soil biological characteristics: a comparison of bulk soil community DNA-, PLFA-, and BiologTM-analyses. Soil Biol. Biochem. 33:1029-1036.

Williams, B.L., S. J. Grayston, and E. J. Reid. 2000. Influence of synthetic sheep urine on the microbial biomass, activity and community structure in two pastures in the Scottish uplands. Plant and Soil 225:175-185.

Wolsing, M. and A. Priemé. 2004. Observation of high seasonal variation in community structure of denitrifying bacteria in arable soil receiving artificial fertilizer and cattle manure by determining T-RFLP of nir gene fragments. FEMS Microbiol. Ecol. 48:261.

Wolter, C. and S. Scheu. 1999. Changes in bacterial numbers and hyphal lengths during the gut passage through Lumbricus terrestris (Lumbricidae, Oligochaeta). Pedobiologia 43:891-900.

Zuberer, D. A. 1994. Recovery and enumeration of viable bacteria. In: Methods of soil analysis: Part 2 microbial and biochemical properties (Weaver, R.W. et al., Ed), pp. 119-142. Soil Science Society of America, Madison, WI. 


\section{APPENDIX I}

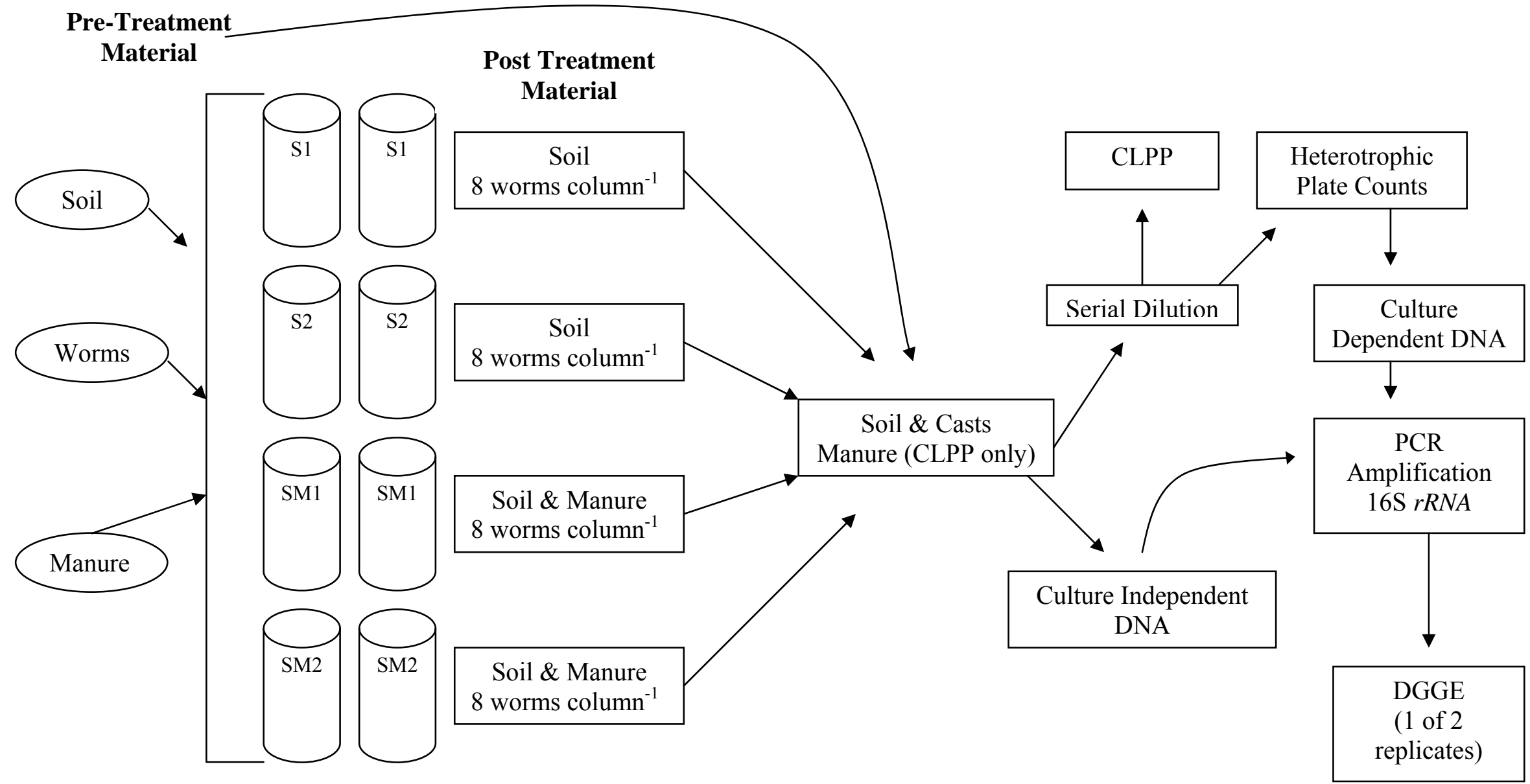

Appendix I A. Summary flow chart describing a preliminary feasibility study used to determine the final experimental design employed in this thesis 


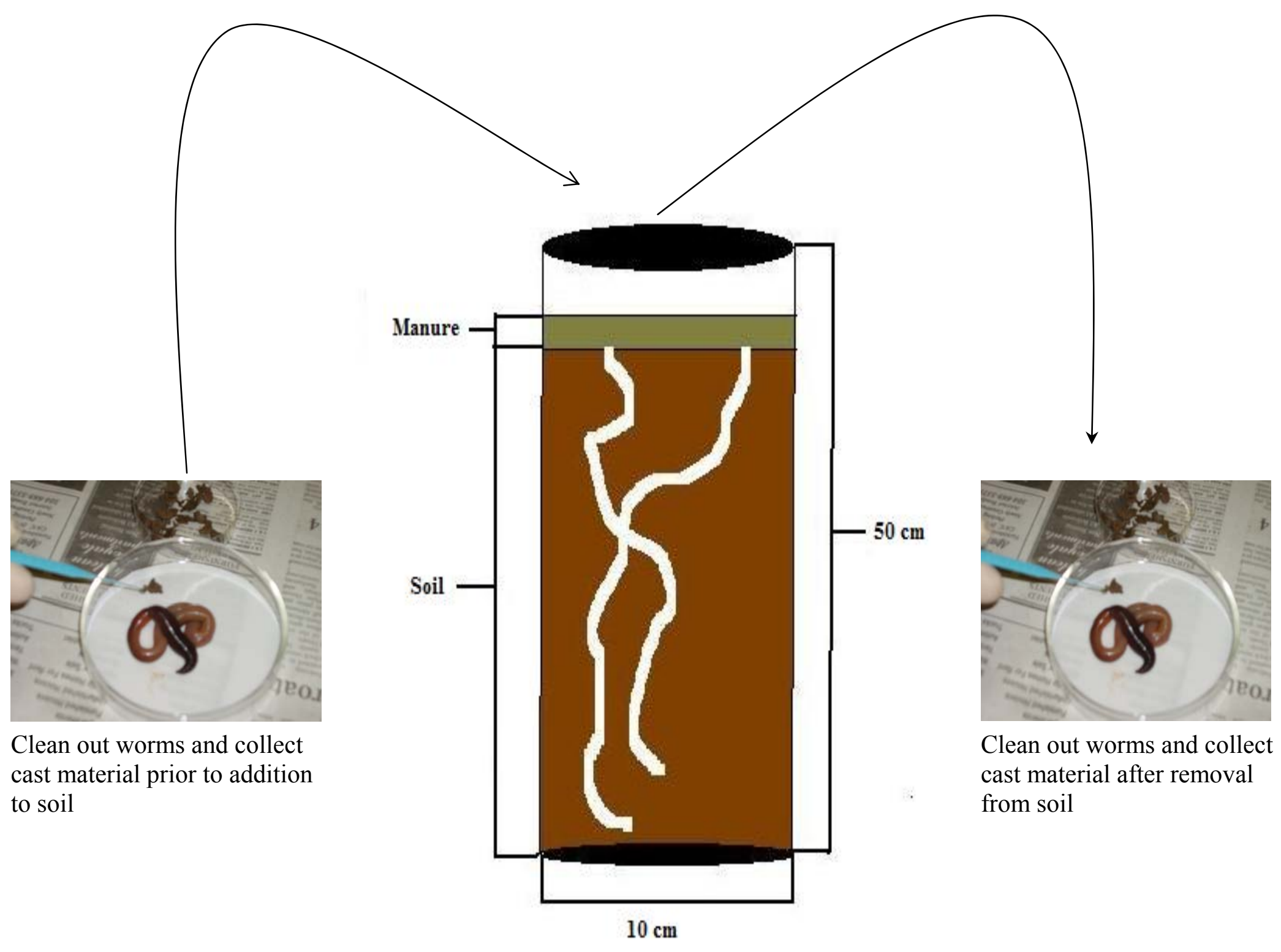

Appendix I B. Feasibility study diagram 
(C)

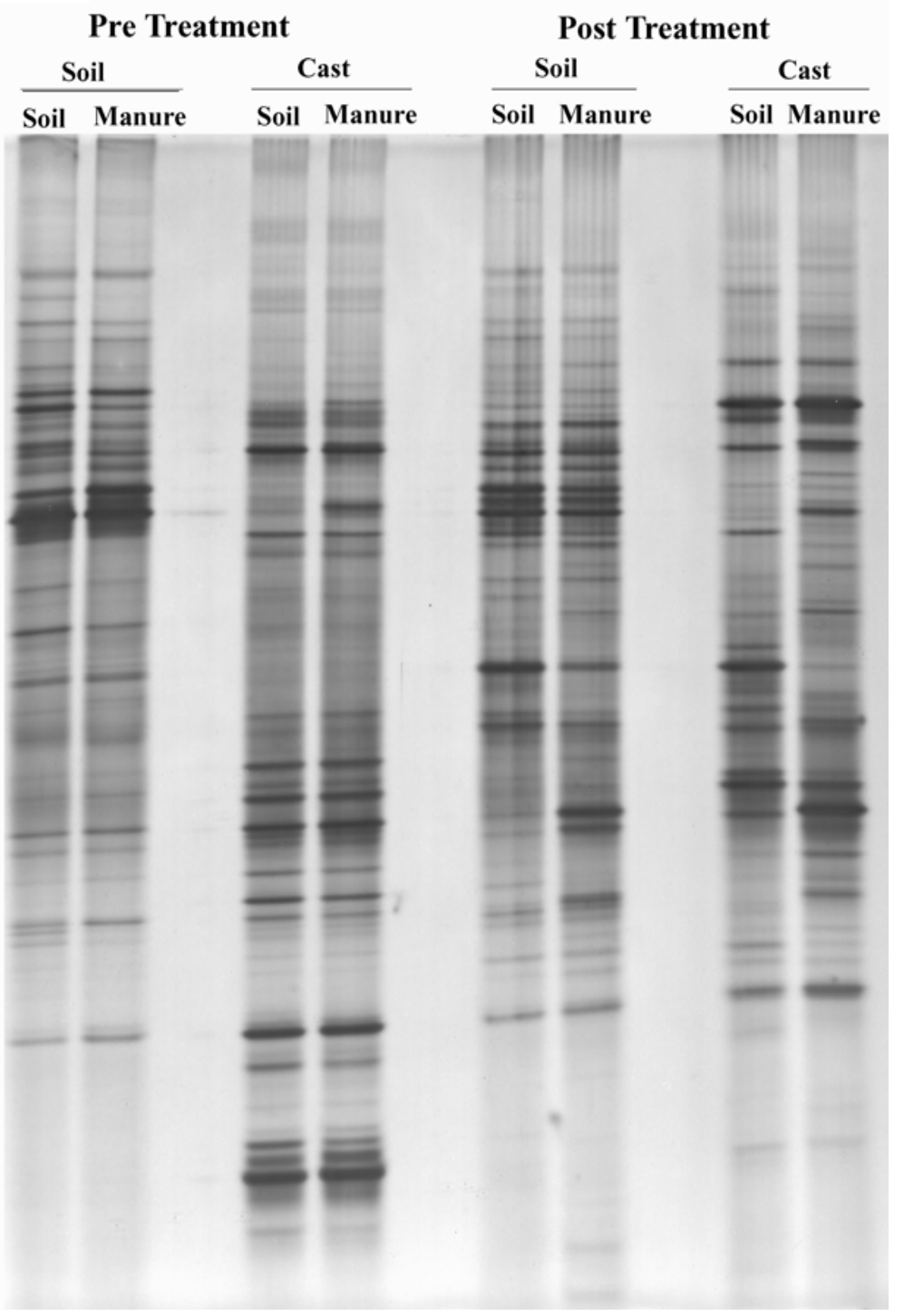

(D)

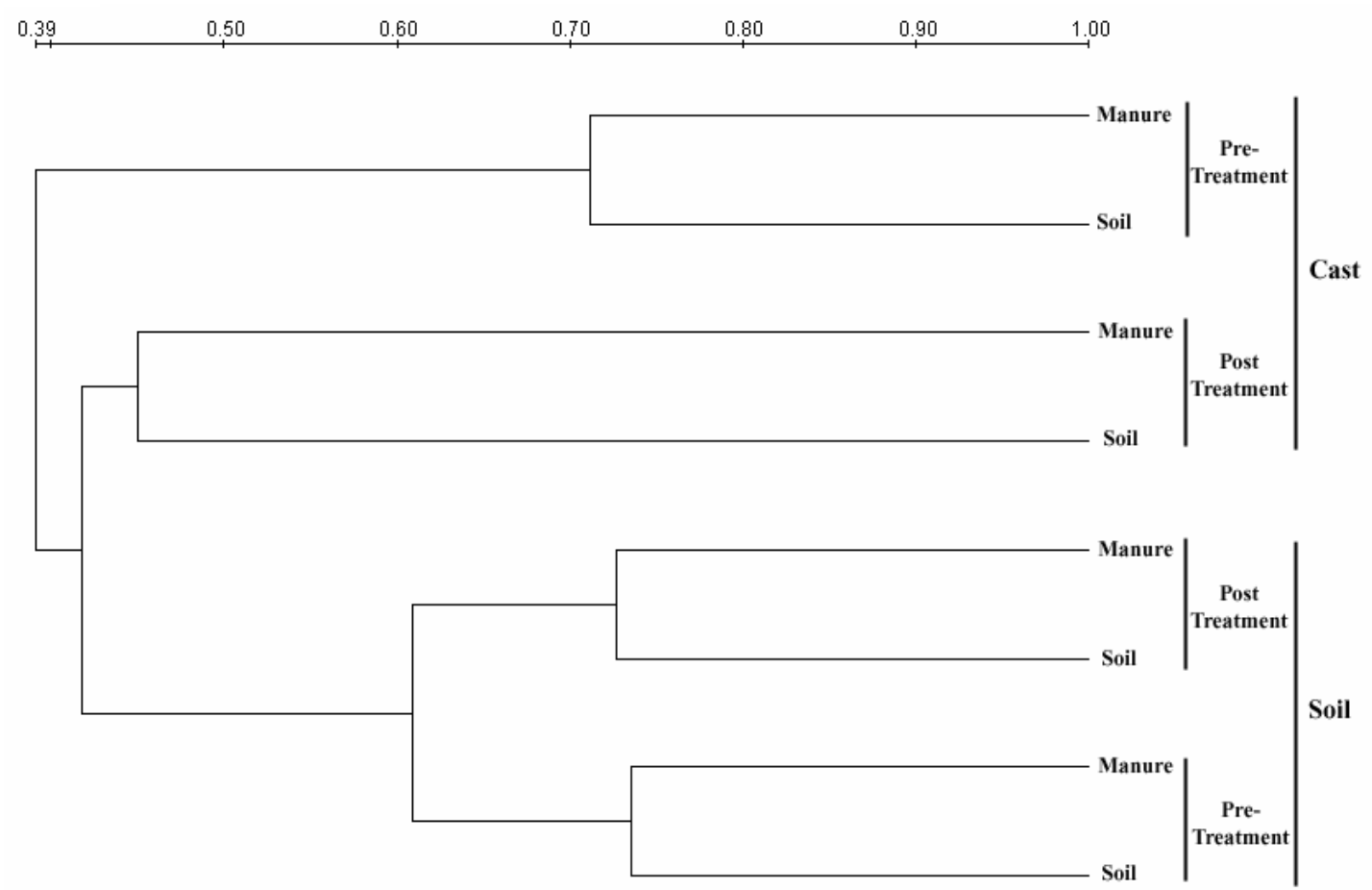

Appendix I. (C) DGGE gel of PCR-amplified 16S rRNA genes amplified from culture-dependent bacterial communities of pasture soil and $L$. terrestris casts. Pre treatment samples are before addition of manure and incubation in soil mesocosms. Post treatment samples are after addition of manure and incubation in soil mesocosms (D) UPGMA dendrograms constructed using the Dice similarity matrix generated from culture-dependent DGGE profiles of PCR-amplified 16S rRNA genes from pasture soil and casts from $L$. terrestris before and after treatment with cattle manure. The scale located above the tree indicates percent similarity. 
(E)

\section{Pre Treatment}

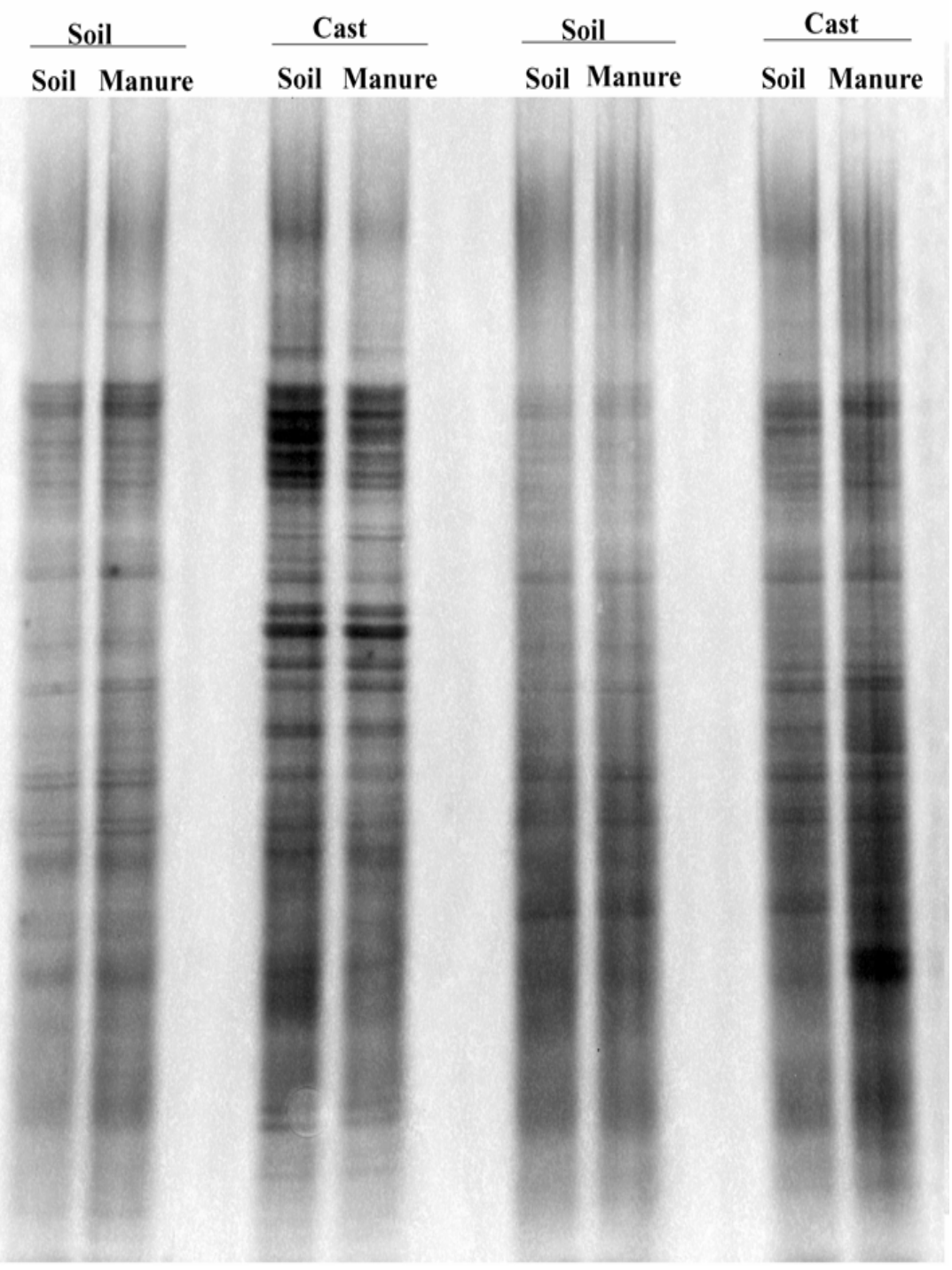

(F)

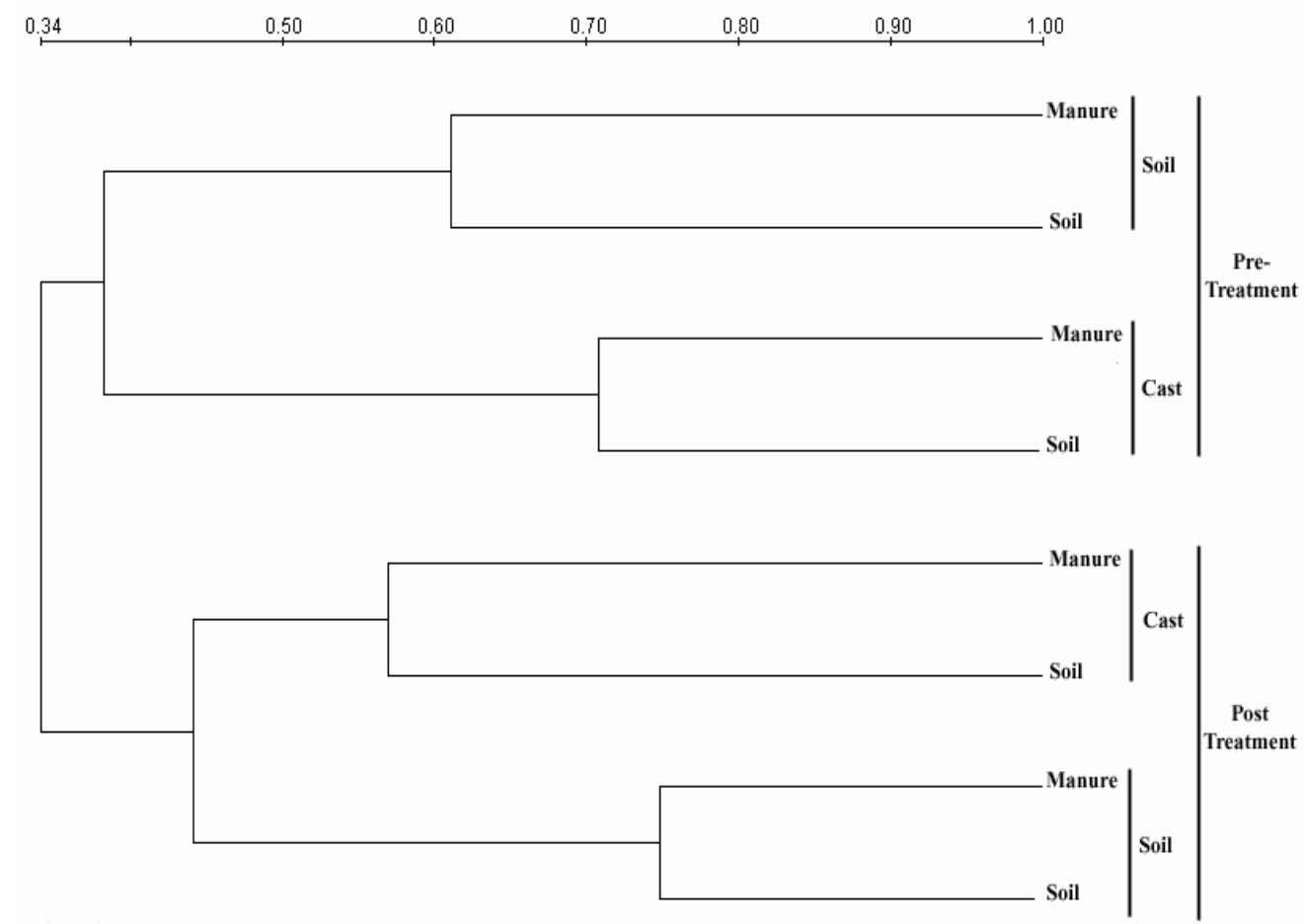

Appendix I. (E) DGGE gel of PCR-amplified 16S $r R N A$ genes amplified from culture-independent bacterial communities of pasture soil and $L$. terrestris casts. Pre treatment samples are before addition of manure and incubation in soil mesocosms. Post treatment samples are after addition of manure and incubation in soil mesocosms (F) UPGMA dendrograms constructed using the Dice similarity matrix generated from cultureindependent DGGE profiles of PCR-amplified 16S rRNA genes from pasture soil and casts from $L$. terrestris before and after treatment with cattle manure. The scale located above the tree indicates percent similarity. 
Appendix I G. Heterotrophic plate count enumerations of soil, L. terrestris casts and manure obtained from $\mathrm{R} 2 \mathrm{~A}$ media after $48 \mathrm{hr}$. incubation at $25^{\circ} \mathrm{C}^{*}$

\begin{tabular}{cccc}
\hline & & \multicolumn{2}{c}{ CFU g $^{-1}$ material $^{-\mathbf{1}^{* *}}$} \\
\cline { 3 - 4 } Material & Treatment & Pre-Treatment & Post Treatment $^{*}$ Soil \\
\cline { 3 - 4 } & Soil & 7.10 & 7.03 \\
& Manure & 7.16 & 6.97 \\
\hline \multirow{2}{*}{ Cast } & Soil & 8.84 & 8.19 \\
& Manure & 8.88 & 8.87 \\
\hline \multirow{2}{*}{ Manure } & - & & 9.39 \\
\hline
\end{tabular}

* Pre treatment samples are before addition of manure and incubation in soil mesocosms. Post treatment samples are after addition of manure and incubation in soil mesocosms

${ }^{* *}$ Geometric mean CFU values $(\mathrm{n}=8)$

$\mathrm{ND}=$ not determined 


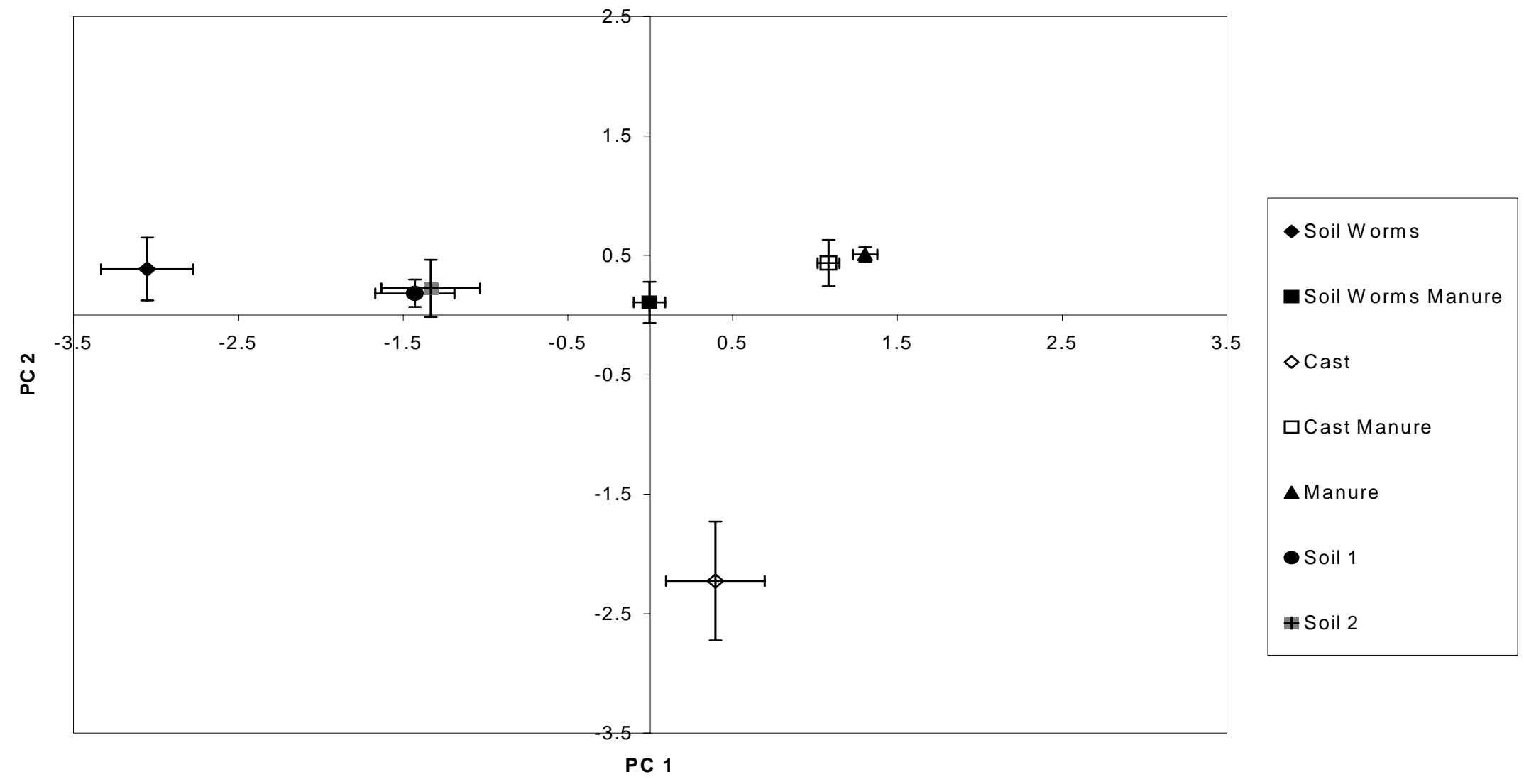

Appendix I H. Principal component analysis based on normalized well color development (average absorbance value for each substrate divided by AWCD) from BIOLOG® GN2 MicroPlates ${ }^{\mathrm{TM}}$ inoculated with soil, earthworm casts or manure. Soil 1 and 2 are soil samples prior to manure treatment. All other samples are post manure treatment. $(\mathrm{n}=6)$ 
APPENDIX II

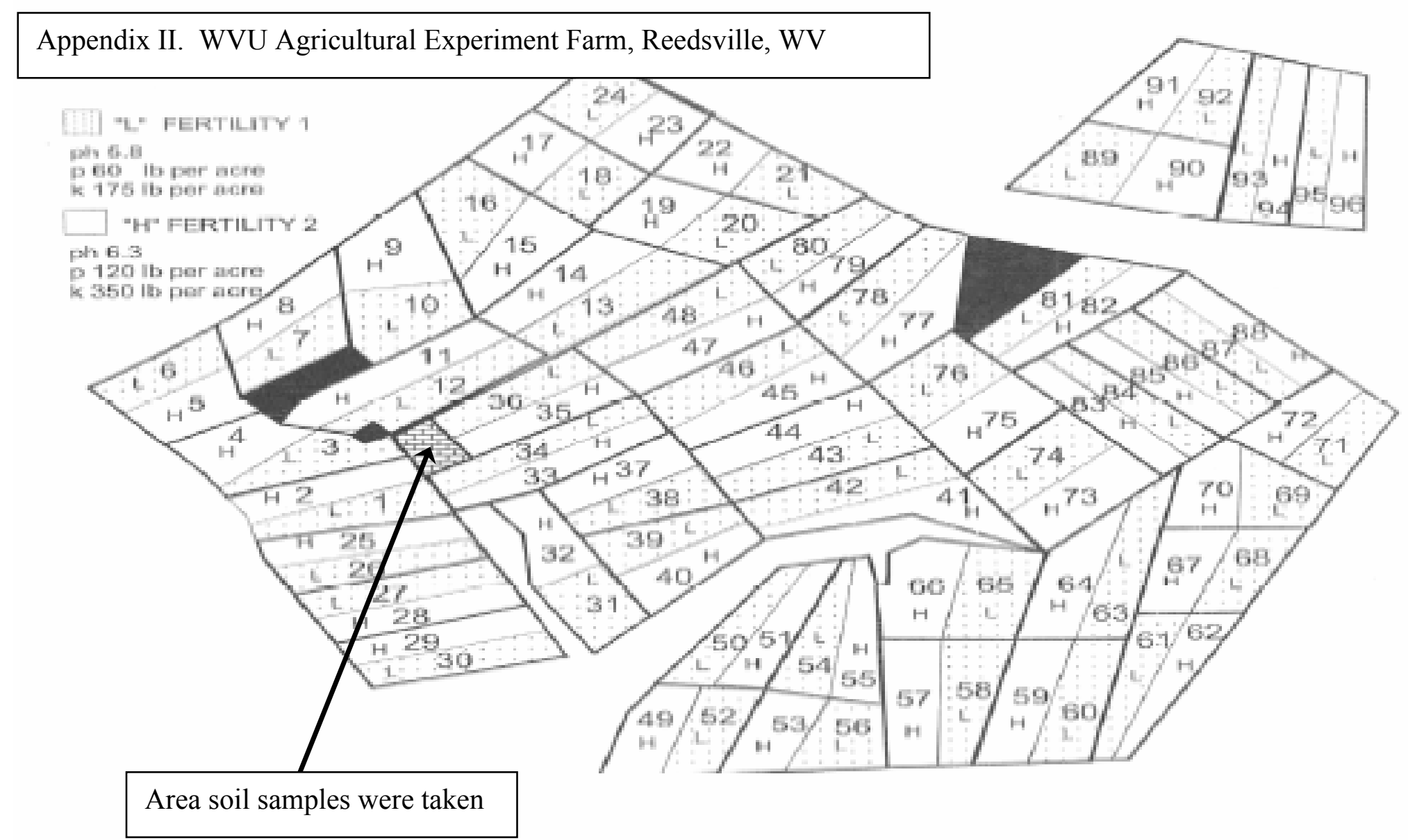

